\title{
Taxonomy, evolutionary History and Distribution of the middle to late Famennian Wocklumeriina (Ammonoidea, Clymeniida)
}

\author{
R. Thomas Becker ${ }^{1}$
}

With 12 figures, 5 plates and 4 tables

\begin{abstract}
Old collections, new records, and data from global literature are used for taxonomic revisions and for a new reconstruction of the evolutionary history of the triangularly coiled clymenids, the Wocklumeriaceae, and their ancestors. Epiwocklumeria applanata is first reported from the topmost Wocklum Limestone at Hasselbachtal and Drewer, and this supports the distinction of an applanata Subzone just prior to the global Hangenberg Event which wiped out the whole group. The Wocklumeriaceae and Glatziellidae record of the famous Oberrödinghausen Railway Cut and of other Rhenish sections is revised. The Maïder of Southern Morocco has yielded first Parawocklumeria patens, paprothae, Wocklumeria sphaeroides plana, Kielcensia ingeniens n. sp., and Synwocklumeria mapesi n. sp. Parawocklumeria distributa Czarnocki forms the type-species of Tardewocklumeria $\mathrm{n}$. gen. Lecto- and neotypes for several taxa are designated. The variability and paedomorphic patterns of Wo. sphaeroides are discussed. The Wocklumeriaceae represent the terminal Famennian (Upper Devonian VI-C/D) radiation of a longranging lineage which evolved in parallel to other clymenid groups. They are characterized by sutural features and by longidomic and very slowly expanding whorls. The polyphyletic traditional Gonioclymeniina are divided into the suborder Wocklumeriina (with Wocklumeriaceae, Glatziellaceae n.superfam. and Biloclymeniaceae) and into the Gonioclymeniaceae of the Clymeniina. Gyroclymenia Czarnocki is regarded as a junior synonym of Pleuroclymenia Schindewolf which, however, does not include the 'Pleuro.' americana and eurylobica groups. Pleuroclymenia represents the ancestral form of the Wocklumeriina and also the phylogenetical link with Platyclymenia (Varioclymenia) of the Clymeniaceae. The Gonioclymeniaceae had their roots in advanced Platyclymeniidae.
\end{abstract}

Key words: Ammonoidea, Clymeniida, Upper Devonian, Famennian, Hangenberg Event, Taxonomy, Phylogeny, Palaeobiogeography.

\section{Zusammenfassung}

Alte Aufsammlungen, Neunachweise und globale Literaturdaten werden für taxonomische Revisionen und für eine neue Rekonstruktion der Evolution der Dreiecksclymenien (Wocklumeriaceae) und ihrer Vorfahren benutzt. Epiwocklumeria applanata wird zum ersten Mal im Hasselbachtal und bei Drewer nachgewiesen, und diese Funde bestätigen die Abtrennung einer applanata-Subzone im unmittelbar Liegenden des Hangenberg-Event, welcher zum Aussterben der gesamten Gruppe führte. Die Verbreitung von Wocklumeriaceae und Glatziellidae im klassischen Profil des Bahneinschnittes bei Oberrödinghausen und an anderen Fundorten im Rheinischen Schiefergebirge wird revidiert. Der Maïder in Süd-Marokko lieferte erstmalig Parawocklumeria patens, paprothae, Wocklumeria sphaeroides plana, Kielcensia ingeniens n. sp. und Synwocklumeria mapesi n. sp. Parawocklumeria distributa Czarnocki bildet die Typus-Art von Tardewocklumeria n.gen. Weiterhin werden die Variabilität und paedomorphe Erscheinungen bei Wo. sphaeroides diskutiert. Die Wocklumeriaceae repräsentieren im höchsten Famennium (UD VI-C/D) die Radiationsphase einer langlebigen phylogenetischen Linie, die sich parallel zu anderen Clymenien entwickelte. Sie ist durch Suturmerkmale und lange Wohnkammern bei niedrigmündigen Gehäusen charakterisiert. Die als polyphyletisch erkannten Gonioclymeniina werden in die Wocklumeriina (mit Wocklumeriaceae, Glatziellaceae n.superfam. und Biloclymeniaceae) und in die Gonioclymeniaceae der Clymeniina geteilt. Gyroclymenia Czarnocki ist ein jüngeres Synonym von Pleuroclymenia Schindewolf, umfasst jedoch nicht die ,Pleuro." americanaund ,Pleuro.' eurylobica-Artgruppen. Die Gattung ist die ursprünglichste Form der Wocklumeriina und stellt gleichzeitig das Bindeglied zu Platyclymenia (Varioclymenia) der Clymeniaceae dar. Die Gonioclymeniaceae wurzeln in fortgeschrittenen Platyclymeniidae.

Schlïsselwörter: Ammonoidea, Clymeniida, Oberdevon, Famennian, Hangenberg Event, Taxonomie, Phylogenie, Palaeobiogeographie.

${ }^{1}$ Museum für Naturkunde, Invalidenstr. 43, D-10115 Berlin, Germany. e-mail: thomas.becker@rz.hu-berlin.de Received April, accepted June 2000 


\section{Introduction}

In one of his most famous and classical papers, Schindewolf (1937) has both investigated the detailed ammonoid biostratigraphy of the German Wocklum-Stufe or Wocklum Limestone (terminal Famennian. Upper Devonian [=UD] VI) and the evolution of triangularly coiled clymenids which represent the most bizarre group of Devonian ammonoids. Since then, a wealth of new data has become available concerning the biostratigraphy (reviews in Becker 1988, 1996: Korn 1993. Korn et al. 1994) and paleobiogeography (Becker 1993a) of ammonoids around the Devonian-Carboniferous boundary. Triangularly coiled clymenids belonging to the Wocklumeriaceae have been described or mentioned from 20 sedimentary basins of five continents (Fig. 1: Europe. Asia, North Africa. North America. South America) giving an almost pantropical distribution in warm-water cratonic shelf areas. A detailed overview of the global record of Wocklumeriaceae genera and species is compiled in Table 1 (for complete references see later text). The list includes new regional records as well as new species. Several members of Kielcensia, Triaclymenia. Tardewocklumeria n. gen. and Synwocklumeria appear to have been endemic.
The richest and most diverse faunas come from Germany (Rhenish Massif and Thuringia), Poland. the Urals, and South China. Clearly, there was not a single evolutionary centre, as former phylogenetic reconstructions based on GermanPolish taxa only (Schindewolf 1937, Korn 1995a, b) might suggest. For the present review and revision. more than 1500 Wocklumeriaceae specimens have been studied.

In the evolutionary model developed by Schindewolf (1937), triangular coiling was invented iteratively in three independent latest Famennian clymenid lineages: in Soliclymenia (Hexaclymeniidae). in the Parawocklumeriidae, and in the Wocklumeriidae. Bogoslovskiy (1981) and Czarnocki (1989), however, later described intermediate forms between parawocklumeriids and wocklumeriids. Korn (1992a, 1995a, b) emphasized their phylogenetic significance and correctly outlined briefly the evolutionary transition between the two families which form a single natural systematic unit, the Wocklumeriaceae. This superfamily is characterized by the following combination of apomorphies: (1) triangularly coiled early to adult stages. (2) weak to strong constrictions in straight whorl parts, and (3) subdivision (or later complete reduction) of both dorsal and ventral lobes.

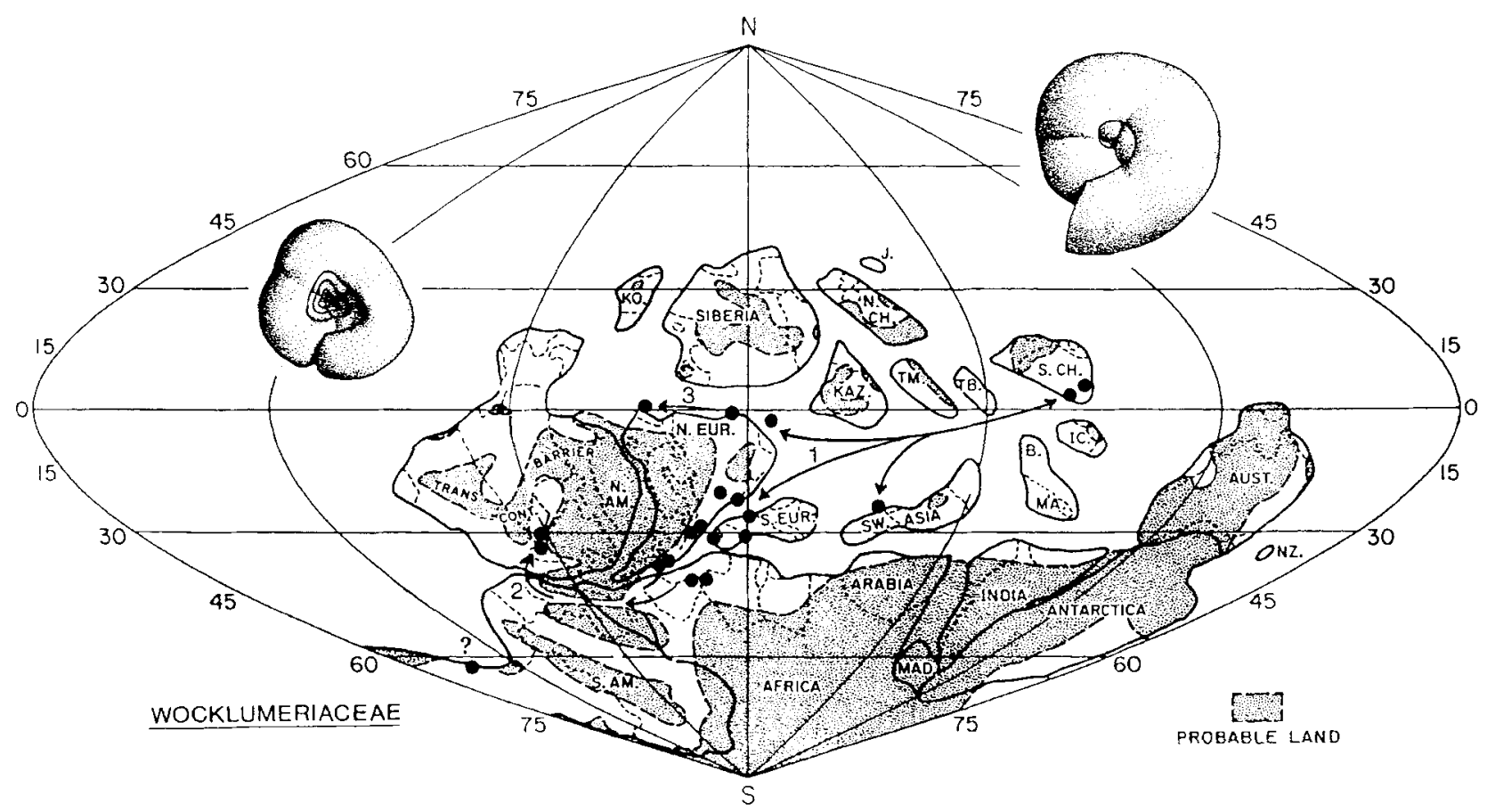

Fig. 1. Global distribution of late Famennian (UD VI-C/D) Wocklumeriaceae showing three routes of potential faunal exchange: 1. along the Prototethys: 2. from North Africa to $W$ of the Appalachians: 3. along the western Ural seaway. The occurence on the Chilenia Terrane (see Breitkreuz 1986) is still questionable. Abbreviations: KO.. Kolyma (NE Siberia), N. and S. CH. North and South China. IC.. Indochina (Vietnam. Kambodia. Laos): B.. Burma (Myanmar); MA.: Malyasia; J., Japan: TB. Tibet: TM. Tarim Plate: Kaz.. Kazackstan: Aust. Australia: NZ.. New Zealand; N. and S. EUR., Northern and Southern Europe: N. and S. AM.. North and South America: MAD.. Madagascar 
As already said, Korn (1995a, b) used only species of the Rhenish Slate Mountains in his phylogenetic reconstruction and, therefore, his model is incomplete and simplified. The longknown sudden and synchronous appearance of parawocklumeriids and later the cryptogenic entry of Wocklumeria in German sections strongly suggests an influence of migrational events on the known spatial and stratigraphic distribution of members of the group. However, it is strange that the entry of such taxa is not correlated with any obvious lithofacies change. Distribution control by subtle ecological factors is further indicated by peak frequencies of specific species in distinctive beds of rather uniform successions (see Parawocklumeria Bed $=$ Bed $98-99 \mathrm{~N}$ at Hasselbachtal, Becker 1996). There is no reason to assume that speciation mostly took place in Germany. Morphologically intermediate species and endemic end-members of lineages are now known from eastern Europe, Asia, North Africa and North America. Based on taxonomic revisions and new systematic descriptions, an attempt is made here to include all these in a new reconstruction of the evolutionary history of the group. It is clear that this can only be a state-ofthe-art model which has to be completed and updated when more, in some cases better preserved and precisely dated material of rare and new taxa is found. The two new species described herein are based on single specimens and they show how obviously incomplete our knowledge still is.

Questions have been raised (compare systematics in Schindewolf 1937 with Korn 1992b) concerning the origin of the Wocklumeriaceae and their relationships with other clymenid groups. Morphological comparisons and taxonomic concepts of related groups will therefore be reviewed. This is aided by some new material of Hexaclymeniidae and certain Platyclymeniidae. A new taxonomic positioning of the Wocklumeriaceae, based on new phylogenetic models, requires a far-reaching revision of traditional clymenid higher-level systematics. This is aided by a new understanding of the ancestry of gonioclymenids and their relatives which, following Korn (1992b), requires the dissolution of the traditional suborder Gonioclymeniina.

Abbreviations and definitions: dm, diameter; wh, whorl height; ah, apertural height; ww, whorl widths; uw, umbilical width. A, adventitious lobes; $\mathbf{E}$, external or ventral lobes; I, internal or dorsal lobes; $\mathbf{L}$, lateral lobes; $\mathbf{U}$, umbilical lobes; a double point in sutural formulas mark the umbilical seam. Longidomic, body chamber longer than one whorl; mesodomic, body chamber between $3 / 4$ and one whorl, brevidomic, body chamber between $1 / 2$ and $3 / 4$ whorl. For late Famennian ammonoid zonation and abbreviations see Becker (1993b, 1996) and Korn (1999). Wo., Wocklumeria; Epiwo., Epiwocklumeria; Synwo., Synwocklumeria; K., Kielcensia; Parawo., Parawocklumeria; Tardewo., Tardewocklumeria; Tria., Triaclymenia; Kampto., Kamptoclymenia; Pleuro., Pleuroclymenia; Progonio., Progonioclymenia; Hexa., Hexaclymenia; Glat., Glatziella; Post., Postglatziella; Platy., Platyclymenia; Vario., Varioclymenia; Trocho., Trochoclymenia; Uralo., Uraloclymenia; Nod., Nodosoclymenia. An * in synonymy lists marks the introduction of taxa, a + refers to records or description of new material.

Institutional abbreviations: MB.- and Oc-numbers refer to material deposited in the Museum für Naturkunde (MfN); GPIG specimens are housed in the Geological Institute of Göttingen University; $\mathbf{Z}$-numbers refer to the collection of the Bundesanstalt für Geowissenschaften and Rohstoffe (BGR) in Berlin-Spandau.

\section{Material and localities}

Fig. 2

\section{Hasselbachtal}

A revision and correlation of the Hasselbachtal Auxiliary Stratotype succession has been published by the author (Becker 1996) and other details were published in Becker et al. (1984), Becker (1988) and Luppold et al. (1994). It has been emphasized that further collecting is likely to fill current record gaps of longer ranging species and to add first records of further species. This was proven by new fieldwork in 1996 to 1998 which produced, amongst others, the first Epiwocklumeria applanata Wedekind (MB.C.2701) from the topmost part (upper $14 \mathrm{~cm}$, Bed $113 \mathrm{aN}$ ) of the Wocklum Limestone.

All collections of Becker (1996) and new material were available for this study. Additional specimens of Wo. sphaeroides sphaeroides (Richter), including many juveniles, were found loose (MB.C.2723.1-18) or came from Beds 100N (MB.C.2720), 106/108N (MB.C.2721.1-2), $113 \mathrm{~N}$ (MB.C.2703, 2718-2719), 113aN (MB.C.2710.1-4), 113cN (MB.C.2710.5-7) and $114 \mathrm{~N}$ (MB.C.2722.1-2). Three new specimens 


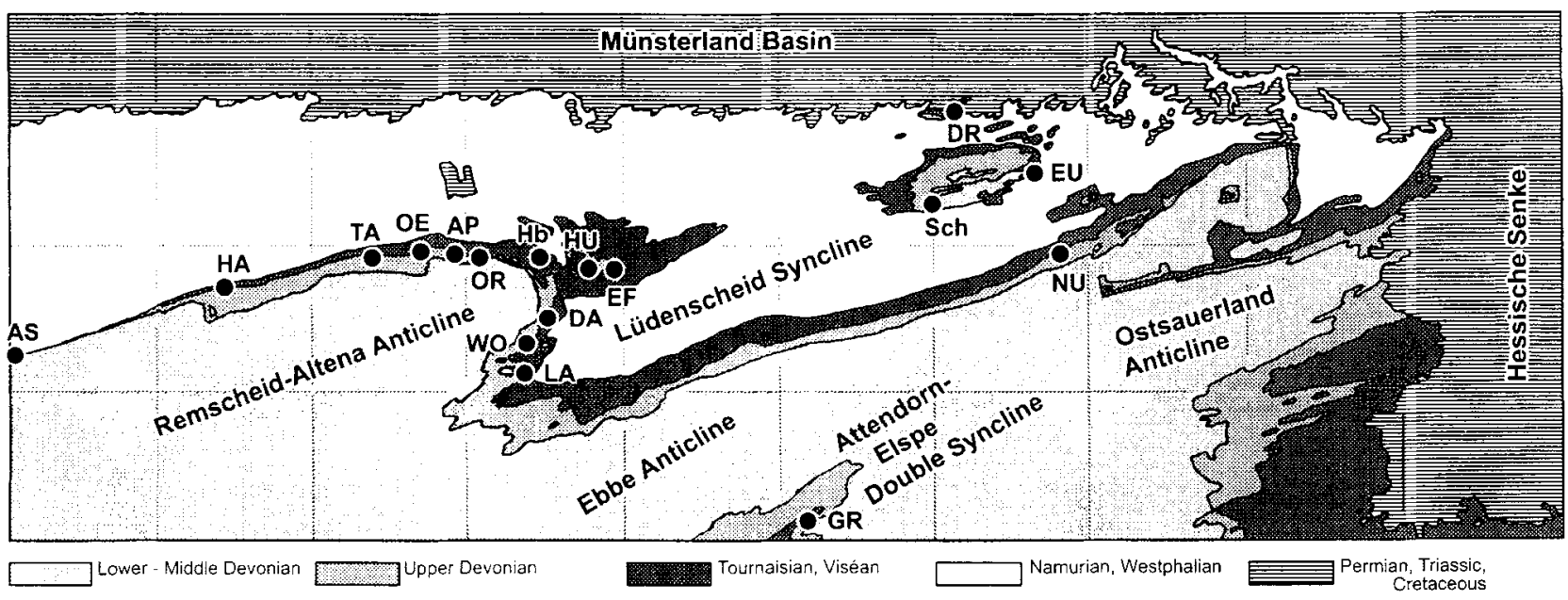

Fig. 2. Geographic position of all known Wocklumeriaceae-localities in the northern part of the Rhenish Slate Mountains. Abbreviations: AS, Aske, E of Hagen; HA, Hasselbachtal. $\mathbf{N}$ of Hohenlimburg; TA, Tannenkopf, $\mathrm{N}$ of Iserlohn (Seiler area); $\mathbf{O E}$, Oese, E of Hemer-Becke and Höcklingsen: AP, Apricke: OR, Oberrödinghausen railway cut and road section; Hb, Hangenberg. NE of Eisborn; HU, Humberg. S of Ainghausen: EF, Effenberg and Müssenberg, NW and N of Hachen; DA, Dasberg near Hövel or Wettmarsen: Wo, Burg or Borkewehr near Wocklum; LA, Langenholthausen/Trachtenberg; Sch, old shooting ground near the Bilstein Cave; DR, Provincial Quarry Drewer: EU, Eulenspiegel; NU, Nuttlar; GR, Grimminghausen. Geological overview taken from Luppold et al. (1994: fig. 1)

(MB.C.2704.1-3) of Wo. sphaeroides plana Schindewolf were found loose, others (MB.C.2702.1-3) came from Bed 113aN.

\section{Oese}

Since Denckmann (1901), the Oese section at the B7 road between Hemer and Menden (sheet 4512 Menden, Fig. 2) has been known as an important Devonian-Carboniferous locality and it has been illustrated by Luppold et al. (1994). However, the ammonoid sequence has not been investigated in much detail and only preliminary data concerning the Wocklum Limestone have been given by Becker et al. (1993). The topmost $35 \mathrm{~cm}$ yielded Wo. sphaeroides sphaeroides (e.g., MB.C.2724-2725 = Oc 1705 and 1774, MB.C.2726), Wo. sphaeroides plana (MB.C.2727 $=\mathrm{Oc}$ 1756), and Parawo. paradoxa (e.g. MB.C.1713-1716 = Oc 1713, 1766, 1709, 1727). Epiwocklumeria has not yet been found and only few Parawocklumeria but no kamptoclymenids or Triaclymenia were collected so far from lower down (UD VI-C) in the sequence.

\section{Oberrödinghausen}

The Oberrödinghausen Railway Cut has been famous since Schindewolf's (1937) pioneer study. A. Denckmann collected at the turn of the century wocklumeriids in the Hönne area but his poor fragments (MB.C.1782.1-3, leg. 1901) were not identified. Schmidt (1924) first recorded Wo. sphaeroides (MB.C.1800.1-13, MB.C.2205 = Wo. sphaeroides plana) and Wo. distorta. Schindewolf (1937) claimed that the latter in fact belong to Parawo paradoxa. This is confirmed by examination of Schmidt's collection (MB.C.1793.1-7), including a figured original (Schmidt 1924: pl.6, figs ?14, 15; MB.C.1727). Since the latter specimen was misoriented, Schmidt illustrated a ventral lobe rather than a ventral saddle. Schmidt (1924) also misidentified some juvenile Wo. sphaeroides as parawocklumeriids (det. Wo. distorta, MB.C.1794.1-2).

Schindewolf's extensive collections of Wocklumeriaceae and glatziellids is available and inventory numbers are given here. However, the holotypes of Wo. sphaeroides plana, Wo. sphaeroides aperta Schindewolf, Kamptoclymenia endogona Schindewolf, Kampto. trigona Schindewolf, Triaclymenia triangularis Schindewolf, Postglatziella carinata Schindewolf, as well as all illustrated Epiwocklumeria and other figured specimens have been lost in the Berlin collection. Fortunately, neotypes for most taxa can be selected from paratypes. Revision of the large parawocklumeriid collection showed that Schindewolf did not distinguish forms with practically closed (Parawo. paradoxa) or small, triangularly open umbilicus (Parawo. paprothae Korn in Clausen et al. 1989a). Poorly preserved involute morphotypes of paprothae and paradoxa are indistinguishable and a perfect separation of both taxa 
probably has not been achieved. In large samples from the sphaeroides Zone, typical (clearly umbilicate) paprothae morphotypes are easy to segregate from paradoxa (see Pl. 4). Some rather involute specimens identified by Schindewolf as Parawo. distorta are better also regarded as open umbilicate morphotypes of Parawo. paprothae.
Since sutures are not preserved in most specimens assigned to distorta, affinities with other convolute triangular clymenids (e.g., Synwocklumeria) known from elsewhere are theoretically possible. The railway cut record, including small recent collections, is as follows (Fig. 3; former Schindewolf identifications are given in brackets):

Bed $1(33-35 \mathrm{~cm})$

Wo sphaeroides sphaeroides (MB.C.912, original of Pl. 2, Fig. 1, intermediate to plana; MB.C.1718.1-33, ?MB.C.1718.34-45, MB.C.2214.1-74, MB.C.2218.1-5, MB.C.2219.1-2)

Wo. sphaeroides plana (MB.C.1721.1-4, including the neotype, ?MB.C.1721.5, MB.C.2215.1-2, MB.C.2216.1-30, MB.C.2217.1-5)

Wo. sphaeroides aperta (MB.C.2220.1-4)

Wo. sphaeroides ssp. juv. (MB.C.1-480)

Epiwo. applanata (MB.C.2221.1-6)

Parawo. paradoxa (MB.C.2715.1-292, 1740.1-11, 1741.1-2)

Parawo paprothae (MB.C.1699.1-10, umbilicate, det. paradoxa)

Bed 1 (9.5-14 cm below top) Wo. sphaeroides cf. sphaeroides (MB.C. 1742.1-2)

Parawo. cf. Parawo. paradoxa (MB.C.1743)

Bed 1 (14-17 cm below top) Parawo. paradoxa (MB.C.1744)

Bed $2(18-20 \mathrm{~cm})$

Wo. sphaeroides sphaeroides (MB.C.1722-1-4)

Parawo. paradoxa (MB.C.2716.1-3, juveniles; MB.C.1726.1-5, specimens with sculpture; MB.C.1746.1-48)

Parawo paprothae (MB.C.1747, umbilicate, det. paradoxa)

Bed 2 (lower ca. $10 \mathrm{~cm}$ )

Wo. sphaeroides juv. (MB.C.1745)

Bed $3(13 \mathrm{~cm})$

Wo. sphaeroides sphaeroides (MB.C.1783.1-7)

Wo. sphaeroides plana (MB.C.1784.1-2)

Wo. sphaeroides aperta (lost)

Mimimitoceras trizonatum Korn juv. (MB.C.1785.1-2, with open umbilicus, det. Wocklumeria)

Parawo paradoxa (MB.C.1786.1-24)

Parawo paprothae (MB.C.1787.2-16, det. paradoxa, mostly involute intermediates to paradoxa,

MB.C.1787.1 typical and with wider umbilicus)

Parawo. paradoxa vel paprothae (MB.C.1788.1-26)

Postglatziella carinata (MB.C.2200.1-36, including the neotype)

Bed $4(13 \mathrm{~cm})$

Wo. sphaeroides plana (MB.C.1749.1-4, det. cf. sphaeroides and sp; 1749.4 perhaps intermediate to aperta)

Parawo. paradoxa (MB.C.1820.1-9)

Parawo paprothae (MB.C.1822.1-8, involute morphotypes, MB.C.1822.6-8, umbilicate morphotypes)

Parawo. paradoxa vel paprothae (MB.C.1821.1-21)

Post. carinata (MB.C.2201)

Bed $5(20-23 \mathrm{~cm})$

Wo. sphaeroides $\mathrm{ssp}$. (squashed, MB.C.1755)

Parawo paradoxa (MB.C.1789.1-20)

Parawo paprothae (MB.C.1790.1-3, det. paradoxa)

Parawo paradoxa vel paprothae (MB.C.1791.1-23)

Postglatziella sp. juv. (MB.C.2222.1-2)

Bed $6(13-15 \mathrm{~cm})$

Parawo. paradoxa (MB.C.1795.1-3)

Parawo paradoxa vel paprothae (MB.C.1811.1-3)

Parawo. paprothae (MB.C.1796.1-2, det. paradoxa; MB.C.1810.1-2, very involute morphotypes)

Glatziella glaucopis Schindewolf (MB.C.554.6.1-10)

Bed $7(18-20 \mathrm{~cm})$

Parawo paprothae (MB.C.1808.1-22, very involute morphotypes;

MB.C.1765, det. distorta, with wider umbilicus)

Parawo. ?paprothae (MB.C.1809.1-24)

Parawocklumeria sp. indet. (MB.C.1775, det. ?paradoxa)

Parawo. distorta (MB.C.1764.1-13, 1764.9 with healed shell fractures, 1764.10 with wrinkle layer, 1764.11 transitional to patens)

Parawo patens Schindewolf (MB.C.1757)

Tria. triangularis (lost)

Kampto. trigona (MB.C.1750.1-3)

Kampto. endogona (MB.C.1813.1-13, including the neotype)

Glat. glaucopis (MB.C.554.7.1-8)

Bed $8(15 \mathrm{~cm})$

Parawo paprothae (MB.C.1760.1-13, det. paradoxa; MB.C.1761.1-2, very involute morphotypes, det. paradoxa; MB.C.1766, det. distorta, with beautiful wrinkle layer, ?MB.C.1819.1-12) Parawo distorta (MB.C.1767.1-2, ?MB.C.1814.1-4, e.p. det. paradoxa)

Parawo. patens (MB.C.1758) 


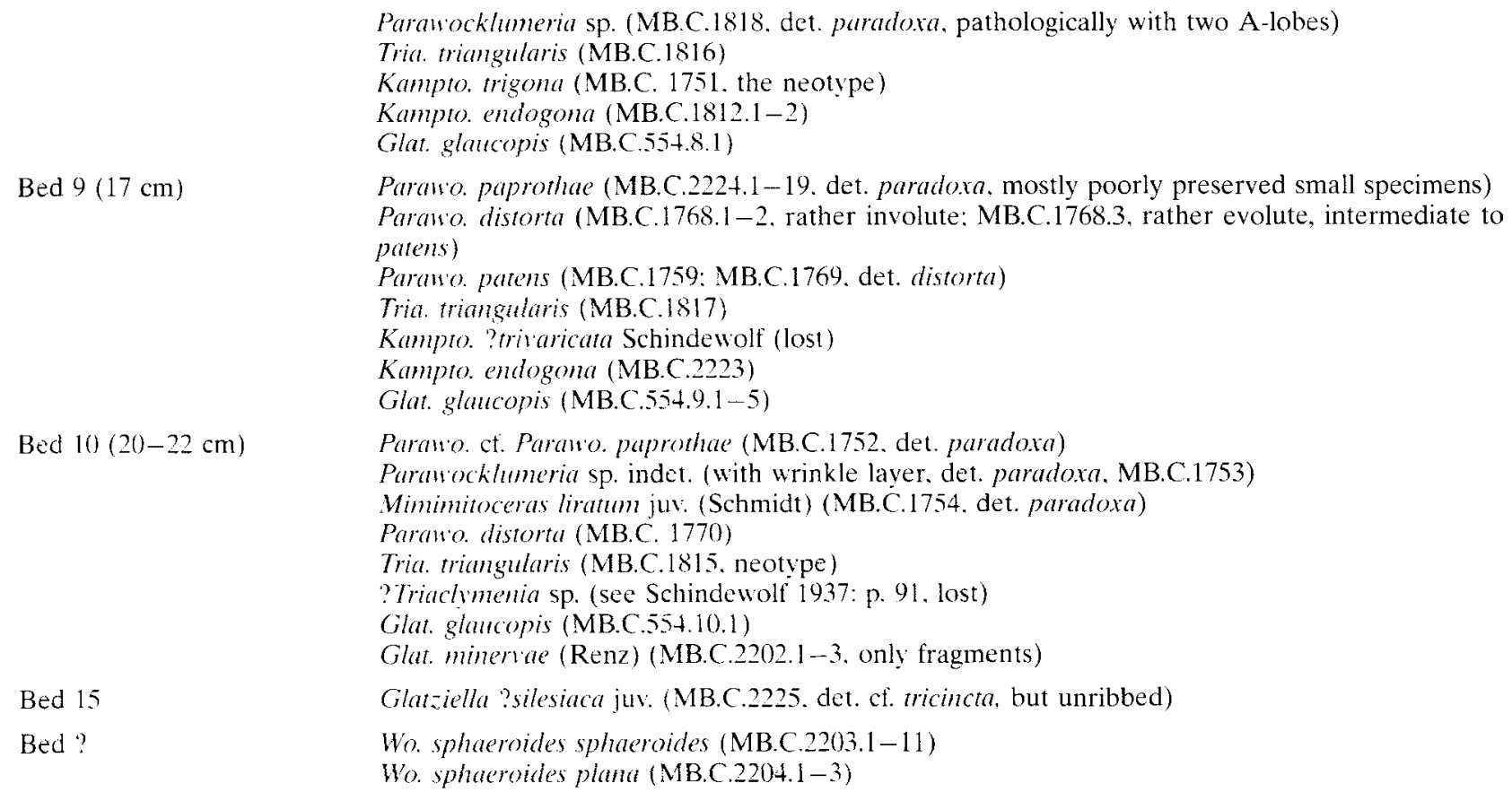

The revision of Schindewolf's collection allows a refinement of taxon ranges and of the Oberrödinghausen zonation (Fig. 3). The paradoxa Zone (UD VI-C) can be divided into a lower paprothae (Luppold et al. 1994) or endogona (VI-C ${ }_{1}$ : Beds $10-7$ ) and an upper paradoxa Subzone (VI-C2: Bed 6, perhaps lower parts of Bed 5). The sphaeroides Zone (UD VI-D 1 ) starts lower than previously thought within Bed 5 . The massive main part of Bed 2 probably correlates with Bed $109 \mathrm{~N}$ at Hasselbachtal, and Parawo. paprothae ranges into the overlying Bed 1 of the applanata Subzone (VI-D ${ }_{2}$ ).

Further specimens of Wo. sphaeroides come from the Road Section nearby (see Luppold et al. 1994) which is overgrown at present. A juvenile (MB.C.1728 = Oc 1688) shows that sutural elements are fully developed very early in ontogeny (at less than $3.5 \mathrm{~mm} \mathrm{dm}$ ).

\section{Burg or Borkewehr near Wocklum}

The type section for the Wocklum Limestone and Wocklum-Stufe near Wocklum (topographic sheet 4613 Balve) is rather insufficiently studied. It yielded Wedekind's $(1914.1918)$ partly lost types of Epiwo. applanata, Wo. denckmanni. and Para110. paradora. A section log and some conodont data were given by Luppold et al. (1994). Available material includes Wo. sphaeroides sphaeroides (MB.C.1725, leg. Wedekind. lectotype of Wo. denckmanni: ?MB.C.1778.1-4. leg. Schmidt in 1920; MB.C.1798, det. Wo. distorta, leg. Schmidt in 1920: MB.C.1724.1-3, collection of Lange from 1923: MB.C.1780, leg. Schindewolf in 1924: thin section, MB.C.2226, leg. Schindewolf in 1924), Wo. sphaeroides plana (MB.C.2227.1-2, leg. Schindewolf in 1924), Parawo. paradoxa (lectotype GPIG 389-100, ?syntypes GPIG 265-267; MB.C.1797.1-2, leg. Schmidt in 1920; MB.C.1776.1-6, leg. Schindewolf in 1924), Parawo. paprothae (GPIG 389-78a, syntype of Parawo paradoxa, original of Wedekind 1918: pl. 19, fig. 17; MB.C.1777.1-2, leg. Schindewolf in 1924), and Parawocklumeria sp. (MB.C.1779, det. Wo. sphaeroides. leg. Schmidt). Lange's (1929) material of Parawo. paradoxa has not been traced in Berlin. Currently there are no specimens of Epiwo. applanata from the type locality available and Wedekind's original is lost.

\section{Drewer}

In the last decade, the Devonian-Carboniferous boundary beds of the famous Drewer Quarry have been intensively re-studied by Korn et al. (1994). Earlier, Schindewolf $(1926,1937)$ reported that Wo. sphaeroides ranges into the Hangenberg Shale (UD VI-E). The former Prussian Geological Survey collection in the Museum für Naturkunde includes a distorted Wo. sphaeroides plana (MB.C.1748), leg. by Schindewolf, and a Wo. sphaeroides cf. aperta (MB.C.1781, det. ?sphaeroides), leg. by Schmidt in 1922 (see notes in Schmidt 1927). New Wocklumeria records come from Becker (1988: 199, MB.C.1683) 
Table 1

Geographical distribution of all currently known members of the Wocklumeriaceae. Abbreviations: C, Chile; In, Indiana: O, Oklahoma; R, Rhenish Massif; T, Thuringia; D, Devon; Co, Cornwall; A. Armorican Massif; M, Montagne Noire; Ta, Tafilalt and Maïder, Southern Morocco; Al; Southern Algeria (Saoura Valley); Ca, Carnic Alps; H, Holy Cross Mountains, Poland; Si. Silesia, Southern Poland; U, Southern Urals; P, Polar Urals; Ba, Bashciria; Ce, Caucasus; G, Guangxi, Southern China; Gz, Guizhou, Southern China. Signs: + record, $\times$ record under different taxonomy, ? questionable record.

\begin{tabular}{|c|c|c|c|c|c|c|c|c|c|c|c|c|c|c|c|c|c|c|c|c|}
\hline taxon & C & In & $\mathrm{O}$ & $\mathrm{R}$ & $\mathrm{T}$ & $\mathrm{D}$ & $\mathrm{Co}$ & A & $\mathrm{M}$ & $\mathrm{Ta}$ & $\mathrm{Al}$ & $\mathrm{Ca}$ & $\mathrm{H}$ & $\mathrm{Si}$ & $\mathrm{U}$ & Po & $\mathrm{Ba}$ & $\mathrm{Cc}$ & $\mathrm{G}$ & $\mathrm{Gz}$ \\
\hline $\begin{array}{l}\text { Kamptoclymenia } \\
\text { - endogona } \\
\text { - trigona } \\
\text { - trivaricata } \\
\text { - endogonoides } \\
\text { - aff. endogona }\end{array}$ & & & & $\begin{array}{l}+ \\
+\end{array}$ & + & & & & & & & $\begin{array}{l}+ \\
+\end{array}$ & $\begin{array}{l}+ \\
? \\
+\end{array}$ & $\begin{array}{l}+ \\
+ \\
+ \\
+\end{array}$ & & & & & & + \\
\hline $\begin{array}{l}\text { Triaclymenia } \\
\text { - triangularis } \\
\text { - primaeva } \\
\text { ? subtriangularis }\end{array}$ & & & & $\begin{array}{l}+ \\
+\end{array}$ & & & & & & & & & $\begin{array}{l}+ \\
? \\
+\end{array}$ & $\begin{array}{l}+ \\
+\end{array}$ & & & & & & \\
\hline $\begin{array}{l}\text { Parawocklumeria } \\
\text { - patens } \\
\text { - paprothae } \\
\text { - paradoxa } \\
\text { - distorta } \\
\text { ? n. sp. }\end{array}$ & & & & $\begin{array}{l}+ \\
+ \\
+ \\
+ \\
+\end{array}$ & $\begin{array}{l}+ \\
+ \\
? \\
+ \\
+\end{array}$ & $\begin{array}{l}+ \\
x \\
?\end{array}$ & $\begin{array}{l}+ \\
+ \\
+ \\
+ \\
+\end{array}$ & & & $\begin{array}{l}+ \\
+ \\
+\end{array}$ & & $\begin{array}{l}+ \\
+ \\
+ \\
+\end{array}$ & $\begin{array}{l}+ \\
\mathrm{x} \\
+\end{array}$ & $\begin{array}{l}+ \\
+ \\
+ \\
+\end{array}$ & $\begin{array}{l}+ \\
\mathrm{x} \\
\mathrm{x} \\
+\end{array}$ & & & & & $\begin{array}{l}+ \\
+ \\
+\end{array}$ \\
\hline $\begin{array}{l}\text { Tardewocklumeria } \\
\text { - distributa } \\
\text { - perplexa }\end{array}$ & & & & & & & & & & & & & $\begin{array}{l}+ \\
+\end{array}$ & & $\begin{array}{l}+ \\
+\end{array}$ & & & & & \\
\hline $\begin{array}{l}\text { Synwocklumeria } \\
\text { - angustilobata } \\
\text { - mapesi n. sp. } \\
\text { - kiensis } \\
\text { - bashcirica } \\
\text { - heterolobata } \\
\text { - dunhevedensis } \\
\text { - sp. }\end{array}$ & & & & & & & + & & & $\begin{array}{l}+ \\
+\end{array}$ & & & $\begin{array}{l}+ \\
+ \\
+ \\
+ \\
x\end{array}$ & & $\begin{array}{l}+ \\
+\end{array}$ & $\begin{array}{l}+ \\
+ \\
+\end{array}$ & $\begin{array}{l}+ \\
+ \\
+\end{array}$ & $\begin{array}{l}+ \\
+\end{array}$ & & \\
\hline $\begin{array}{l}\text { Epiwocklumeria } \\
\text { - applanata } \\
\text { - ?sp. }\end{array}$ & & $\begin{array}{l}? \\
+\end{array}$ & & $\begin{array}{l}+ \\
+\end{array}$ & & & & & & & & & $\begin{array}{l}+ \\
+\end{array}$ & & & & & & & \\
\hline $\begin{array}{l}\text { Kielcensia } \\
- \text { ingeniens } \mathrm{n} . \mathrm{sp} . \\
-b . \text { bohdanoviczi } \\
- \text { b. inaequilobata } \\
- \text { b. pusilla } \\
- \text { n. sp. }\end{array}$ & & & + & & & & & & & $\begin{array}{l}+ \\
+\end{array}$ & & & $\begin{array}{l}+ \\
+ \\
+ \\
+\end{array}$ & & & & & & & \\
\hline $\begin{array}{l}\text { Wocklumeria } \\
\text { - s. plana } \\
\text { - s. sphaeroides } \\
\text { - s. aperta }\end{array}$ & $?$ & & & $\begin{array}{l}+ \\
+ \\
+ \\
+\end{array}$ & $\begin{array}{l}+ \\
+ \\
+ \\
+\end{array}$ & & $\begin{array}{l}+ \\
+ \\
+\end{array}$ & $\begin{array}{l}+ \\
+\end{array}$ & $\begin{array}{l}+ \\
?\end{array}$ & $\begin{array}{l}+ \\
+ \\
+\end{array}$ & $\begin{array}{l}+ \\
+ \\
+ \\
+\end{array}$ & $\begin{array}{l}+ \\
+\end{array}$ & $\begin{array}{l}+ \\
+ \\
+ \\
+\end{array}$ & & $\begin{array}{l}+ \\
+\end{array}$ & & & & $\begin{array}{l}+ \\
+\end{array}$ & $\begin{array}{l}+ \\
+\end{array}$ \\
\hline & C & In & $\mathrm{O}$ & $\mathrm{R}$ & $\mathrm{T}$ & $\mathrm{D}$ & $\mathrm{Co}$ & A & $\mathbf{M}$ & $\mathrm{Ta}$ & $\mathrm{Al}$ & $\mathrm{Ca}$ & $\mathrm{H}$ & $\mathrm{Si}$ & $\mathrm{U}$ & Po & $\mathrm{Ba}$ & $\mathrm{Cc}$ & $\mathrm{G}$ & $\mathrm{Gz}$ \\
\hline
\end{tabular}

and Korn (1988) but the youngest occurence is in nodules sitting in dark grey shale right below the true Hangenberg Black shale marking the global mass extinction level (topmost UD VI-D; Bed 4 of Korn 1988; Bed 16a of Clausen et al. 1989b; Bed WA/93 of Korn et al. 1994). An Epiwo. applanata (MB.C.2229) found in May 1998 in WA/93 gives evidence that the last nodules belong in the applanata Subzone (UD VI-D $)_{2}$. Poorly preserved other Wocklumeriaceae sampled in 1996/98 consist of Wo. cf. Wo. sphaer- oides plana (MB.C.1738.1) and Wo. sphaeroides sphaeroides (MB.C.1738.2) from Bed WA/93, and of Parawo. paradoxa from WA/91b (MB.C.1739.1-2). According to Schmidt (1924: 151, det. ?Wo. distorta), the latter species ranges also into the "lower part of Hangenberg Shale" (= Bed 93). Korn et al. (1994) did not include the taxon in their list of common species of the sphaeroides Zone at Drewer. Three specimens (MB.C.1799.1-3) lleg. by Schmidt in 1921 are unidentifiable ?Parawocklumeria. 


\section{Other localities in the northern Rhenish Massif}

see Fig. 2

A number of other Wocklum Limestone localities formed the basis for the studies around the Devonian-Caroniferous boundary by Schmidt (1924). Clymenids were deposited in the former collection of the Prussian Geological Survey and are now in the Museum für Naturkunde. There are, for example, a Parawocklumeria sp. (det. Wo. denckmanni) from Dasberg (sheet Balve. MB.C.1774, leg. Schmidt in 1920; compare Lange 1929: 31) and faunas from $\mathrm{N}$ of Riemke (sheet Iserlohn, leg. Paeckelmann in 1920): Glat. ?glaucopis (MB.C.2208). Parawocklumeria sp. (MB.C.2209, det. distorta). The topmost Wocklum Limestone from between Apricke and Riemke has yielded to Schmidt (leg. 1921) Wo. sphaeroides sphaeroides (MB.C.2210.1-4) and Parawo paradoxa (MB.C.2211.1-2). As early as 1900. A. Denckmann has collected Wo. sphaeroides sphaeroides (MB.C.2212.1-4) from a brook cut $\mathrm{N}$ of Apricke. A brief description of the Apricke succession was given in Luppold et al. (1994).
Becker (1997a) has briefly reviewed the occurence of Wo. sphaeroides plana at Aske NW of Hagen (sheet 4610 Hagen), the westernmost wocklumeriid locality in the Rhenish Massif (Paeckelmann 1932). Schindewolf (1926: 114, 1937) mentioned the occurence of Parawocklumeria sp. and Cymaclymenia sp. (MB.C.2717) from the Seiler area, W of the Tannenkopf near Iserlohn (sheet 4612 Iserlohn). The parawocklumeriid (MB.C.2712) is a negative that cannot be identified with more precision.

Schindewolf (1937: 41) also recorded the Wocklumeria-Stufe at the Humberg near Ainghausen (sheet 4613 Balve). This is based on collections from 1935 which include Wo. sphaeroides sphaeroides (MB.C.1771.1-5) and Parawo. paradoxa (MB.C.1804). Another locality was created during excavations for a water pipeline in the forest $350 \mathrm{~m}$ SW of Stiepel (northern border of sheet Balve). The outcrop yielded Parawo. paprothae (MB.C.1772.1-2, one specimen with $29 \mathrm{~mm} \mathrm{dm}$ ) and Parawo. cf. Parawo. paradoxa (MB.C.1773.1-2). From Langeloh near Langenholthausen (leg. Paeckelmann), there are Wo. sphaeroides ssp. (MB.C.1801) and Parawo. para-

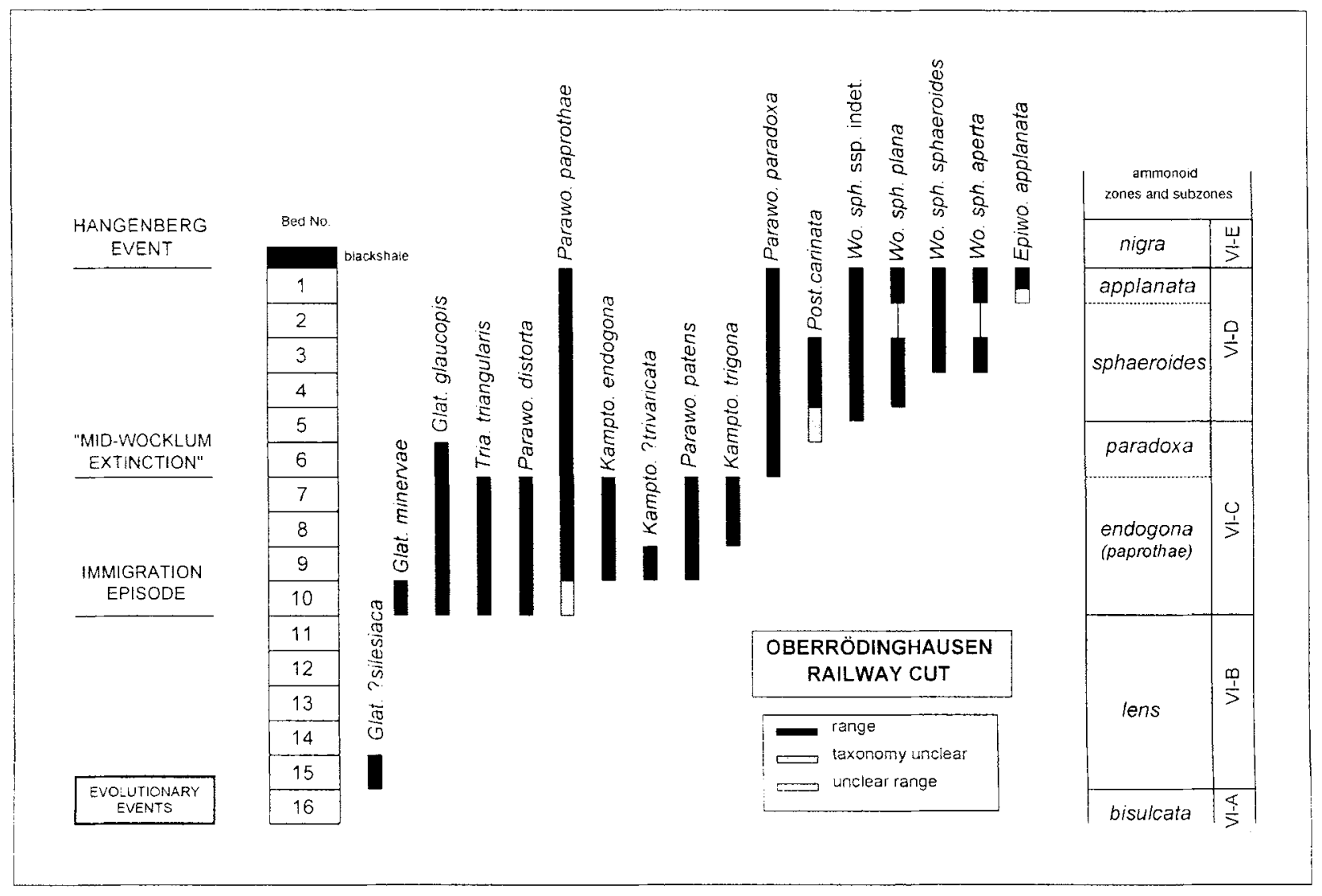

Fig. 3. Ranges of Wocklumeriaceae and Glatziellidae in the Oberrödinghausen railway cut section, based on a revision of the collections of Schindewolf (1937) in the Museum fur Naturkunde. For lithological details see the log in Luppold et al. (1994). The sudden disappearance of open umbilicate taxa indicates a distinctive "Mid-Wocklum Extinction" well below the global Hangenberg Event marked by the spread of blackshales 
doxa (MB.C.1802). Two additional Wo. sphaeroides (MB.C.1803.1-2) were found by Henke near Langenholthausen.

Other authors have reported Parawocklumeria and Wocklumeria from additional localities (Fig. 2) but material was not available for this study: Höcklingsen (? = Oese), Hangenberg, Effenberg, Müssenberg, Trachtenberg, Bilstein, Eulenspiegel, $\mathrm{N}$ of Nuttlar. References are given in the review of the distribution of individual taxa.

\section{Kellerwald}

A. Denckmann collected in 1895 from dense red micrites at the Hauern near Bad Wildungen (labelled as "Adorf Limestone") a Parawo. paradoxa (MB.C.2709) which, however, was assigned by Schmidt (1924) to Wo. distorta. A correct identification of the same specimen was given by Schindewolf (1937: 44). Schmidt (1933) reported also Wo. sphaeroides (det. Wo. denckmanni) from Braunau but material has not survived in Berlin.

\section{Thuringia}

The Schleiz region (Berga Anticline) yielded so far only few Wocklumeriaceae. These are Parawo. patens? of Müller (1956) (MB.C.2713), a Parawo. distorta (MB.C.552) described by Weyer (1981) from the Geipel Quarry (section now destroyed), and Wo. sphaeroides from the Kahlleite-East Quarry (Bartzsch et al. 1995, section currently covered). Bartzsch \& Weyer (1980, 1982) described and illustrated Wo. sphaeroides (with all three subspecies) and Parawo. paradoxa from the Saalfeld area. Kamptoclymenia does also occur in the region (oral comm. D. Weyer 1998), and the paradoxa material probably includes Parawo. paprothae. For this study, material deposited in the collection of the Bundesanstalt für Geowissenschaften (BGR) in BerlinSpandau was examined in detail. It includes two of Richter's (1848) syntypes of Wo. sphaeroides (X4895-96), 77 specimens of Wo. sphaeroides sphaeroides from Fischersdorf-West (Z542-605, collection Barzsch 1962, det. Schindewolf, material of Pfeiffer 1954; Z526; Z23.1-2, leg. Gründel; Z670.1-2, det. Wo. plana), six specimens of Wo. sphaeroides plana from Fischerdorf-West (Z671.1-2 to Z673.1-2), six specimens of Wo. sphaeroides sphaeroides from FischersdorfEast (Z667.1-2, Z668.1-4), a Wo. sphaeroides sphaeroides from Gleitsch (Bed 10, No. 2339), Wo. sphaeroides sphaeroides from a road outcrop $\mathrm{W}$ of Fischersdorf (Bed 10, 2338.1-12, 2340.1-5), and a Wo. sphaeroides plana (2337.1) from the latter locality. This rather large suite allows a good insight into the morphological variability of Thuringian Wocklumeria. The regionally youngest Wo. sphaeroides (Beds 32.8 to 32.10, MB.C.2172-73) were recently described from shales right below the Hangenberg event layer by Bartzsch et al. (1998).

\section{Dzikowiec (Ebersdorf)}

The rich terminal Famennian ammonoid faunas from Dzikowiec in Silesia have been described by Schindewolf (1937), and later by Lewowicki (1959). The Ebersdorf collection of the former Prussian Geological Survey mostly burnt during the 2nd World War and there are only some blackened remains in the MfN of a former significant assemblage. Preserved are the juvenile Kampto. trigona illustrated by Schindewolf (MB.C.2711) and a Parawo. cf. paradoxa (MB.C.2228). Unfortunately, the holotype of Soliclymenia solarioides (Münster) is lost. The holotype of Glat. tricincta Schindewolf (X5673), Glat. cf. tricincta (Schindewolf 1937: pl. 3, fig. 2, X5671), and the holotype of Glat. diensti Schindewolf (X5675) are deposited in the BGR collection at Spandau (see Pl. 2).

\section{Tafilalt and Maïder, Southern Morocco}

The Fezzou area of the Maïder, southern Morocco (see map in Becker 1995) is famous for its well-preserved haematitic and calcareous Famennian ammonoids but a detailed description of faunas and sections has only just began. Already Hollard \& Jacquemont (1956: footnote on p. 23) and Hollard (1963) listed the presence of questionable (cf.) Wocklumeria at the Jebel Aguelmous. This is confirmed by new specimens collected near Fezzou by the author (MB.C.2707-2708) and by V. Ebbighausen (MB.C.3066). They belong to untypically smallsized morphotypes of both Wo. sphaeroides sphaeroides and sphaeroides plana. Similar specimens have been illustrated by Petter (1960) from the Saoura Valley (Marhouma) of southern Algeria. The best succession along the Aguelmous is exposed $\mathrm{S}$ of M'bidia (Lambida) where limestone nodules from just below the reddish weath- 
ering Hangenberg blackshale have yielded small to median-sized Wo. sphaeroides ssp. (MB.C.3064.1-4). A part of the specimens shows intensive overgrowths by bryozoa and tabulate corals on both sides of the shell. Several meters below, in a unit with Balvia (Kenseyoceras) lens Korn. a single Parawo. patens has been discovered by J. Bockwinkel (Leverkusen). In the southern Maïder, at Mrakib (see Becker et al. 1999 and Korn 1999), a relative small Wo. sphaeroides sphaeroides was found by $\mathrm{R}$. Feist.

A haematitic Parawo. paprothae (leg. Ebbighausen, Eb-C19 = MB.C.) from the Fezzou area (Loc. 54) represents the first record of a second species of the genus from the Maïder. Weyer (1995) pointed out, that the cephalopod limestone succession at the Djebel Erfoud of the Tafilalt (see map in Becker 1993a) ranges also into the Parawo paradoxa Zone, and this was recently confirmed by a Parawo. paradoxa illustrated by Korn (1999).

\section{Oklahoma}

Over (1992) mentioned the presence of wocklumeriids in the terminal Devonian parts of the Woodford Shale of Oklahoma. These specimens belong to a new species of Kielcensia with two and a half evolute and triangular whorls without constrictions which follow involute early stages. A detailed description will be published in cooperation with American colleagues.

\section{Comment on the terminal Devonian ammonoid zonation}

The Hasselbachtal and Drewer Epiwocklumeria end doubts (Becker 1996) whether an applanata Subzone (UD VI-D 2 : see Korn 1993. Luppold et al. 1994: table 2) can be recognized in the upper part of the sphaeroides Zone (= Upper paradoxa Zone). Previously, the species has been found in succession only at Oberrödinghausen: the holotype came from the Borkewehr near Wocklum. As discussed below. Epiwo. dunhevedensis Selwood may be better placed in Synwocklumeria. It cannot be used to recognize the typical Epiwocklumeria level in Cornwall. Unfortunately, no precise data are available whether the Kowala fauna of Czarnocki (1989) with Epiwo. applanata, Wo. sphaeroides, Parawocklumeria distorta (Tietze) and Kielcensia came from a single unit (see comment by Dzik 1991). It indi- cates, however, that the applanata level is not only useful on a regional scale but also for interbasinal correlation. Epiwo applanata and perhaps Cymaclymenia evoluta (see Korn et al. 1994) are the only ammonoids that first appear in strata just below the Hangenberg mass extinction level at the base of the Hangenberg blackshale (Fig. 3). Although rather rare, applanata thus characterizes an important last phase in clymenid evolution which, following the concept of Schindewolf (1937), seems useful to be separated at subzonal level.

\section{Evolution and distribution of the Wocklumeriaceae}

\section{General aspects}

The reconstruction of the evolution of triangular clymenids suffers from endemic distributions and cryptogenic sudden and ca. simultaneous appearances of taxa with different level of morphological specialisation (Korn 1995a). The lack of visible sutures in many specimens may prevent the recognition of the true spatial and time distribution of some species. Another problem is the common large intraspecific variability in longidomic, bottom-dwelling (demersal or suprabenthic) ammonoids. Low selective pressure in niches that did not require rapid lateral swimming or which were not affected by high water agitation resulted in poor or unfixed streamlining (highly variable whorl and umbilical width). Typical goniatite examples are cheiloceratids (Becker 1993a) and Prolobites delphinus Sandberger \& Sandberger. The latter not only has variable conchs but also differently shaped sutures in individuals (compare Bogoslovskiy 1969: fig. 51). Excessive shell variabilities have not been observed in primitive members of the Wocklumeriaceae (Kamptoclymenia, Triaclymenia) but apply to Parawo paradoxa and Wo. sphaeroides, and this has to be taken into account in taxonomic concepts. Sutural variabilities in Prolobites delphinus alter the shape and size of saddles and lobes but not the general pattern and sutural formula. Much less variation is found in the complexly lobed Wo. sphaeroides (compare diagrams in Schindewolf 1937, Bogoslovskiy 1981, Czarnocki 1989, and Becker 1996). In Wocklumeriaceae with less developed lobes and saddles (see Parawo. laevigata Bogoslovskiy 1981: fig. 50; large Schindewolf collection), there are variations of the shape and amplitude of elements 
and common sutural asymmetries but the overall sutural pattern remains stable. An exception is a Parawocklumeria from Bed 8 at Oberrödinghausen (MB.C.1818) with three shallow flank lobes on one side of the distorted shell which may be a pathological phenomenon. Unfortunately, the other side of the asymmetric specimen is not well-preserved.

Generally, it is believed that at least larger sutural details were always functional in the whole group and ontogenetic changes provide, as in all other Palaeozoic ammonoids, insights into the evolutionary history. The gradual transformation from simple-lobed early forms to the stratigraphically younger more and more elaborate sutures of Wocklumeriidae shows that septal shapes were determined by selection pressure. Sutural complication is seen as an evolutionary strategy to increase the surface and capacity of intra-cameral organic sheets allowing faster pumping of cameral liquids and greater vertical mobility. In taxa living close to the substrate, this perhaps aided escape movements.

The revision and reconstruction of the evolutionary history is based on morphological comparison of all known Wocklumeriaceae taxa in combination with known time ranges (stratophenetic analyses and interpretation of morphological series). It has to be viewed as state-ofthe-art model. Since the spatial distribution of most Wocklumeriaceae was strongly influenced by rapid migrational effects (Figs 1 and 3 ) in the palaeotropics (and subtropics), there is no strong emphasis on aspects of the paleobiogeographical history. The developed evolutionary model is characterized by parallel and iterative changes in whorl involution and sutural simplification or complication. In accordance with Korn (1995a, b), five phylogenetic trends can be identified from records which provide a framework for interpretation:

1) Older clymenids lack triangular stages and early Wocklumeriaceae (partly) have only short early ontogenetic triangular stages - derived and younger taxa all have expanded triangular stages in ontogeny. This heterochronic trend was reversed only in additional (hypermorphic) mature stages of some youngest taxa.

2) Ancestors and early Wocklumeriaceae are (extremely) evolute - derived and later forms are increasingly involute. Again, a reversal of this rule is only observed in additional (hypermorphic) stages of some youngest species.

3) Older taxa and early ontogenetic stages have simple sutures with few elements (six lobes)
- most derived and younger taxa have more complex sutures (up to ten lobes).

4) Ancestors and early taxa have rounded and rather shallow lobes - most derived and later taxa developed deep (lingulate) or even pointed lobes.

5) Some early taxa have keels at maturity - derived and younger forms show no traces of a keel or of ventrolateral furrows.

The shell and suture ontogeny normally reflects the phylogeny of ammonoids. Shell features in Wocklumeriaceae, however, were introduced at various stages giving examples of palingenesis (peramorphosis), paedomorphosis and of proterogenesis (as defined by Schindewolf 1925).

\section{Evolutionary history and distribution of Para- wocklumeriidae}

\section{Kamptoclymenia Schindewolf, 1937}

The Parawocklumeriidae comprise all clymenids with triangularly coiled ontogenetic stages which have no lobes in median position both on the venter or dorsally. Kamptoclymenia is regarded as the initial member of the Wocklumeriaceae since it is among the oldest of the superfamily (UD

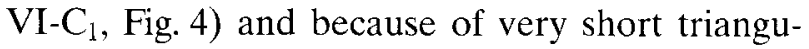
lar stages and due to morphological characters which are present in stratigraphically older (potentially ancestral) clymenids: extreme evolution, mature keels, simply rounded lobes. The sutural formula for the genus is E/2A:I/2 (Fig. $5 \mathrm{a}, \mathrm{b}$ ).

In morphological terms, the extremely evolute Kampto. endogona Schindewolf with short, early ontogenetic triangular stage and moderately depressed whorl cross-section from the endogona Subzone (= paprothae Subzone) appears to be the starting point for the incredibly successful evolution of the Wocklumeriaceae (Figs 6a, 7). The species is known from Germany (Schindewolf 1937: Oberrödinghausen, Korn 1993: Müssenberg) and Poland (Dzikowiec: Phenacoceras ?paradoxum Frech, 1902, non Münster; Kowala, Holy Cross Mountains: aff. endogona Czarnocki, 1989).

Kamptoclymenia n.sp. of Becker (1988) is very poorly preserved and probably does not belong to the genus (Becker 1996). Evolute shell form and sutures resemble Trochoclymenia; the only specimen came from just below the Balvia (Kenseyoceras) lens Zone which roughly correlates with the age of that genus in Silesia. Close to Kampto. endogona is Kampto. endogonoides 


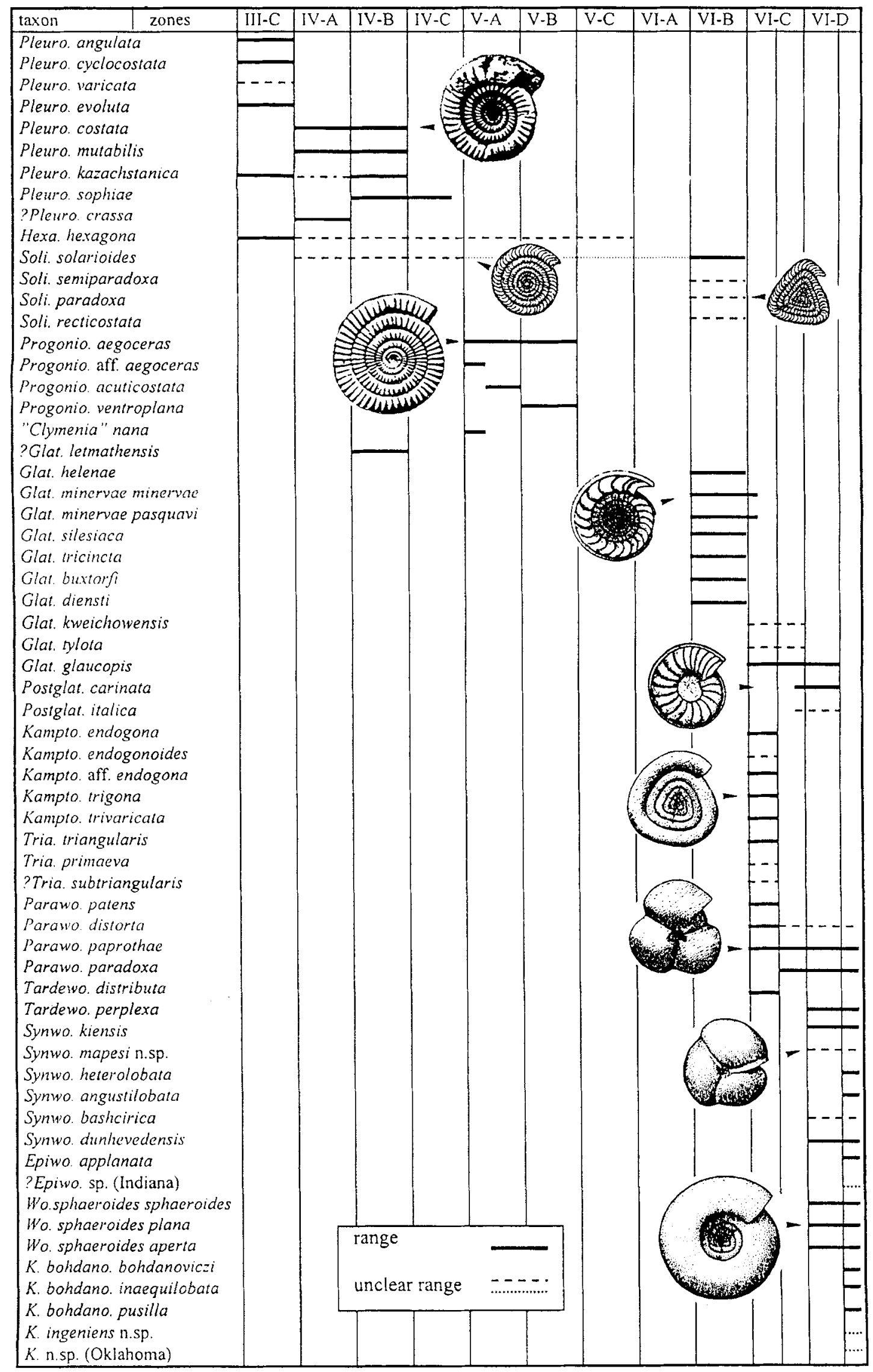

Fig. 4. Known stratigraphical ranges of all valid Wocklumeriaceae and Glatziellaceae n. superfam. Described species not recognized are as follows: Grro. rotundata Czarnocki (= Pleuro. costara). Platv. (Vario.) kazachstanica simplex Kind $(=$ Pleuro. kasachstanica). Glat. multicostata Sun \& Shen (= Glat. minerve minervae). Paravo. laevigata Selwood (= Parawo. paradoxa), Parawo. laevigata obesa Selwood (= Parawo. paradoxa). Kielcensia mirabilis Czarnocki (? = Synwo. dunhevedensis). Wo. denckmanni Wedekind (= Wo. sphaeroides sphaeroides) 

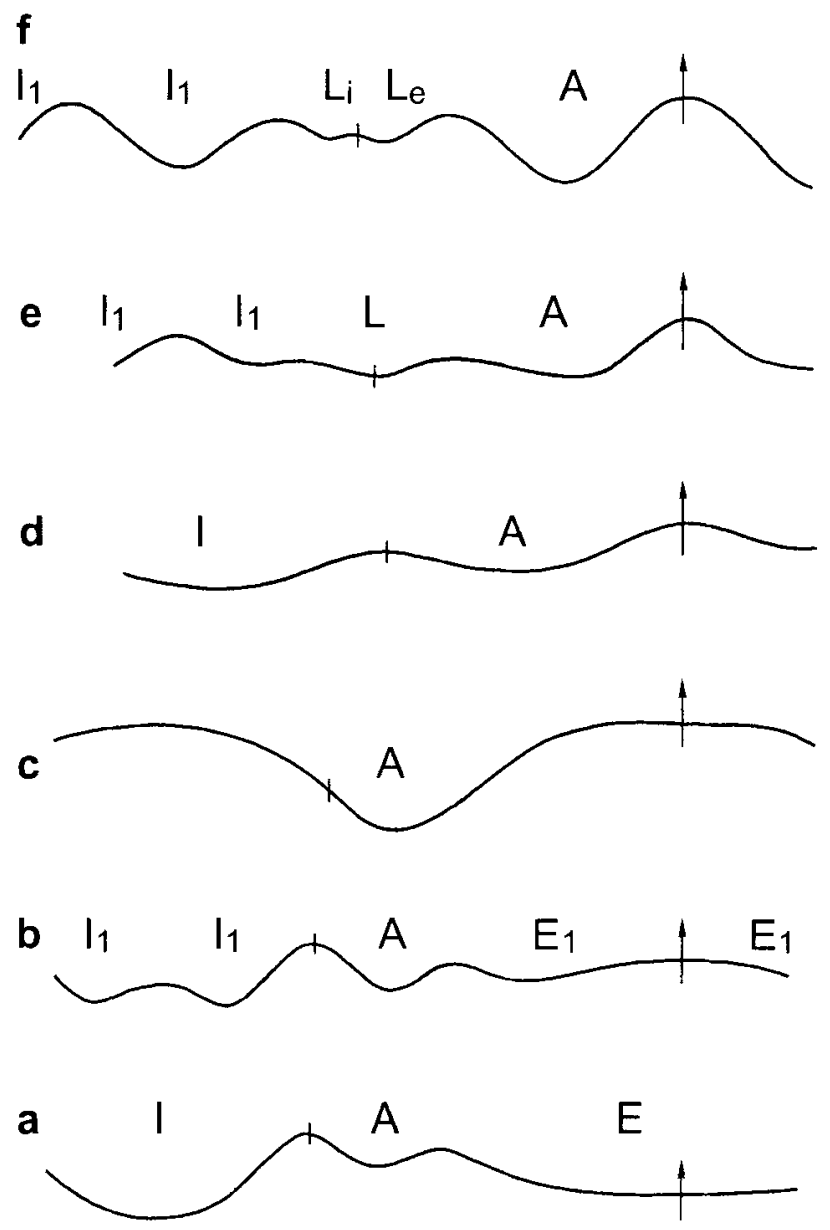

Fig. 5. Published sutural ontogenies in various genera of the Parawocklumeriidae; a, Kamptoclymenia endogona (after Schindewolf 1937: fig. 20a), juvenile stage; b, Kamptoclymenia endogona (after Schindewolf 1937: fig. 20b), adult stage; c, Triaclymenia triangularis (after Schindewolf, 1937: fig. 22), adult stage; d, Parawo paradoxa (after Czannocki 1989: pl. XLIII, fig. 2a), very early stage; e, Parawo. paradoxa (after Czarnocki 1989; pl. XLIII, fig. 2b), juvenile stage; f, Parawo. paradoxa (after Czarnocki 1989: pl. XLIII, fig. 2c), adult stage
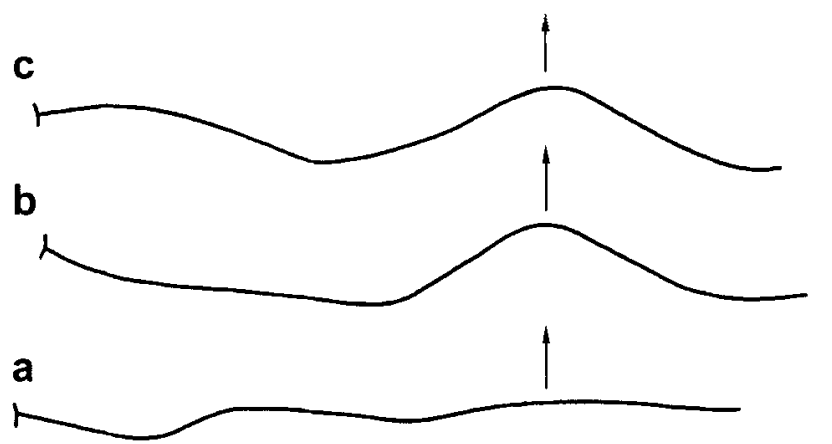

Fig. 6. Sutures in Kamptoclymenia and Parawocklumeria specimens. a, Kampto. endogona, neotype, MB.C.1813.1, Oberrödinghausen Railway Cut, Bed 7, at ca. $13 \mathrm{~mm} \mathrm{dm}(2.7 \mathrm{~mm}$ wh); b, c, Juvenile Parawo, paprothae, MB.C.3061, from the Fezzou area, Maidder, at $5.8 \mathrm{~mm} \mathrm{dm} / 3.3 \mathrm{~mm}$ wh (a), and at $6.3 \mathrm{~mm} \mathrm{dm} / 3.6 \mathrm{~mm}$ wh (b). Sutures resemble early stages in Parawo paradoxa as illustrated by Czarnocki (1989)
Ruan from the terminal Devonian of South China (Guizhou: Wangyou; Ruan 1981). It has the broader whorls seen in Kampto. trigona Schindewolf which again extended the triangular juvenile stage (Fig. 7). This pattern is characteristic of the proterogenetic mode of evolution as described by Schindewolf $(1925,1937)$ but reduction of maximal shell size from ca. $26 \mathrm{~mm}$ in Kampto. endogona to $15-20 \mathrm{~mm}$ in Kampto. trigona supports the idea of Korn (1995b) that this includes neotenic developments after a new feature (triangular whorls) was abruptly introduced in earliest post-embryonic stages. Greater shell involution, a second important phylogenetic trend, was observed by Schindewolf (1937: 90) in a single specimen which he still included in Kampto. trigona. The species occurs in the endogona Subzone of the Rhenish Massif (Schindewolf 1937: Oberrödinghausen, Korn 1993: Müssenberg), perhaps in the Carnic Alps (photo shown by D. Korn) and Poland (Schindewolf 1937: Dzikowiec, ?Kowala: Tria. cf. Tria. triangularis Czarnocki, 1989, only pl. XI, fig. 14,). Kampto. trivaricata Schindewolf from the endogona Subzone of Dzikowiec (Aganides paradoxus Frech, 1904, non Münster) and perhaps also from Oberrödinghausen (Schindewolf 1937) is the most advanced kamptoclymenid (Korn 1992a, b) in which triangular coiling extended into the adult, keeled stage, and involution has proceeded as well (Fig. 7).

\section{Triaclymenia Schindewolf, 1937}

It is an open problem, whether Triaclymenia represents an evolutionary side-branch (left out in Korn 1995b: fig. 12.4) or an intermediate between Kamptoclymenia and Parawocklumeria as suggested by Schindewolf (1937). In adult Kamptoclymenia, the adventitious lobe on the flanks is deeper and more prominent than the divided ventral lobe (Schindewolf, 1937: figs 20-21; see Figs 5b, 6a). Tria. triangularis Schindewolf from the endogona Subzone of Oberrödinghausen is almost as evolute as Kampto. trivaricata (Fig. 7) but it is significantly more compressed. There is a deep flank lobe, by comparison most likely the A-lobe, but both ventral and dorsal lobes, present in all other related and groups, are completely reduced (Schindewolf, 1937: fig. 22; reillustrated in Figure 5c). This leaves a pair of A-lobes next to a very elevated and prominent ventral saddle. Outer sutures are similar in the somewhat more involute Tria. primaeva Czarnocki from Kowala (probably endogona Sub- 
zone) which may be regarded as a descendent (Fig. 7), suggesting a triaclymenid lineage in parallel with the main evolution of triangular clymenids. However, the absence of dorsal lobes is not yet proven in primaeva, and more material may rule out possible affinities with open umbilicate parawocklumeriids. Specimens figured by Czarnocki (1989) as Tria. cf. Tria. triangularis may all or mostly not belong to the genus. The keeled Aganides subtriangularis Frech from Dzikowiec (Fig. 7) is perhaps close to Tria. primaeva but lacks adult constrictions. Due to the lack of sutures, the systematic position cannot be clarified but the subtriangular coiling at late stages leaves the possibility that the species represents an early branch of Kampto. trigona that became more involute. Generally, Triaclymenia is still a rather poorly known genus.

\section{Parawocklumeria Schindewolf, 1926}

In typical Parawocklumeria, the lobe next to the ventral saddle is the most prominent one (Figs $5 \mathrm{~d}-\mathrm{f}, 6 \mathrm{~b}-\mathrm{c})$. Schindewolf (1937) regarded it as an equivalent of the flank lobe of Triaclymenia which has migrated towards the venter since new lobes were introduced around the umbilicus. The sutural ontogeny of Parawo paradoxa illustrated by Czarnocki (1989: pl. XLIII, fig. 2a-c: re-illustrated in Figure 1d-f) both supports and contradicts Schindewolf's idea of a Triaclymenia-Parawocklumeria link. It shows an early ontogenetic flank lobe bordering a simple ventral saddle (as in Triaclymenia) that migrates slightly to the venter and becomes deep and prominent. On the dorsal side, however, a shallow dorsal lobe as in Kamptoclymenia is present which is subdivided subsequently by a mid-dorsal saddle. At the umbilical seam, a lateral lobe appears at the same time (Figs 5e, 6c) which is later divided by a small saddle. The shallow lobes around the umbilicus may disappear or melt with the main flank lobe in deeply constricted whorl segments (Fig. 6b). The sutural ontogeny of Parawocklutmeria suggests that it branched off from Kamptoclymenia in parallel with Triaclymenia. In the Parawocklumeria branch, the dorsal lobe was kept whilst it was completely reduced in Triaclymenia. The sutural formula of Parawocklumeria is interpreted to be $A\left(L_{c}: L_{i}\right) I / 2$.

The moderately evolute (uw $0.33-0.42 \% \mathrm{dm}$ ) and adult keeled Parawo. patens Schindewolf (Fig. 7) from the endogona Subzone (UD VI-C 1 ) of Poland (Schindewolf 1937: Dzikowiec) and
Germany (Schindewolf 1937: ?Oberrödinghausen; Müller 1956: ?Geipel Quarry, MB.C.2713, Pl. 4: 11. 12; Korn 1993: Effenberg) is regarded as the most primitive member of the genus (see also Korn 1995b). It resembles and was probably derived by early ontogenetic sutural changes from the more evolute Kampto. trivaricata. Tria. triangularis can be seen as a more compressed sister species. Very typical for patens is the subtriangularly shaped and high ventral saddle. If sutures are not visible, uncertainties may remain concerning the correct identification of evolute and convolute triangular clymenids. This explains why Schindewolf (1937) added a query to patens material from Oberrödinghausen. New collections from endogona Subzone equivalents of the Maïder suggest that the species occurs also in southern Morocco.

The convolute (uw $0.2-0.33 \% \mathrm{dm}$ ) Parawo. distorta (Fig. 7) may be regarded as an intermediate between patens and the more involute parawocklumeriids that have lost their mature keel traces due to neoteny. However, all available illustrations of distorta sutures (Schindewolf 1937: fig. 26, Bogoslovskiy 1981: fig. 49, Ruan 1981: fig. 82a, b, Czarnocki 1989: pl. XLIII, fig. $6 \mathrm{~b})$ show a ventral saddle which differs in its broad flattening and in the occasional presence of an incipient shallow median ventral lobe significantly from the subtriangular saddles found in other species of the genus Parawo. distorta is regarded as the evolutionary starting point for a new lineage characterized by the re-introduction of median ventral lobes which is the main apomorphy of the Wocklumeriidae. At present there is insufficient knowledge of intraspecific variability of Parawo. distorta and sutures have not been illustrated for the type of Tietze (1871). Schindewolf (1937) re-figured the holotype but did not show its sutures. Possibly there are two convolute parawocklumeriids with different (triangular or flattened) ventral saddles which lead to different descendant groups (Parawo. paprothae and Tardewocklumeria n.gen.) but at present this remains speculation. Forms assigned to Parawo. distorta have been reported from the Rhenish Massif (Schindewolf 1937: Oberrödinghausen, Clausen et al. 1979: Bilstein Cave), Thuringia (Weyer 1972, 1981: Geipel Quarry, MB.C.552), Silesia (Tietze 1871), the Holy Cross Mountains (Czarnocki 1989: Kowala), Cornwall (Selwood 1960: Oldtree Lodge), the Carnic Alps (Gaertner 1931: Großer Pal), and Southern Urals (Bogoslovskiy 1981). Specimens illustrated by Ruan (1981) have rather narrow umbilici. The same 

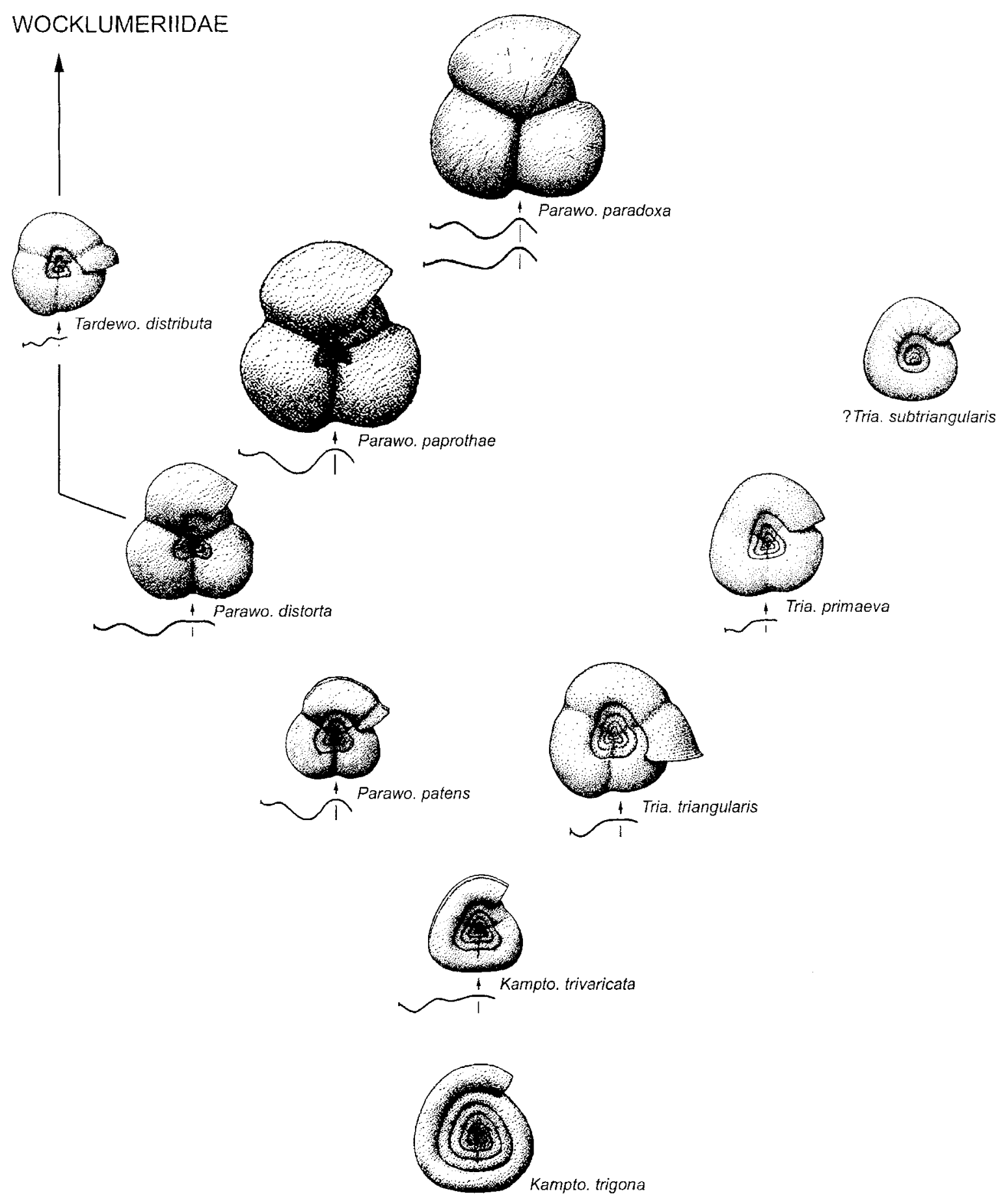

\section{PARAWOCKLUMERIIDAE}

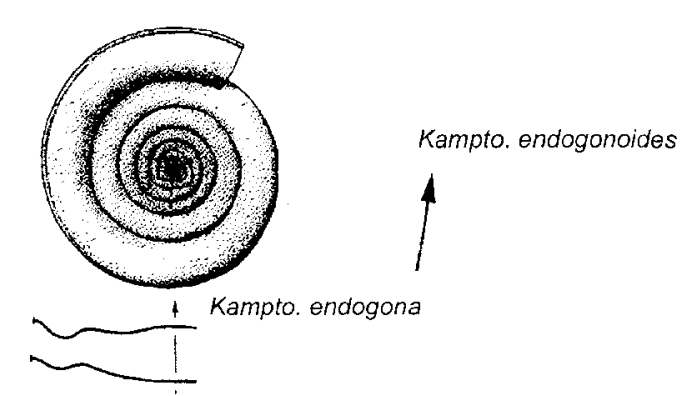

Fig. 7. Morphological series illustrating the reconstructed phylogeny of the Parawocklumeriidae. All illustrations are in identical magnification $(\mathrm{ca} . \times 0.75)$ in order to show size effects of paedomorphic trends. The introduction of triangular coiling in early stages of Kampto. endogona and its subsequent extension into adult stages is a typical example of proterogenesis as defined by Schindewolf $(1925,1937)$ 
applies to a specimen from Chudleigh. South Devon (House \& Butcher 1973) which was illustrated in Selwood et al. (1984). The Chinese and Devon forms perhaps belong to Parawo paprothae.

The Oberrödinghausen distorta material of Schindewolf (1937), and probably also the Geipel specimens. came from the endogona Subzone. Czarnocki (1989) reported distorta in association with riphaeoclymenids (under the names Liroclymenia and Dimeroclymenia) not only from (?the lower part of) the paradoxa Zone (UD VI- $C_{1}$ ) but also together with Wocklumeria. Epiwocklumeria and Kielcensia. This suggests a longer range (UD VI-D) than in the classical German sections. The largest known. somewhat questionable distorta (MB.C.1814) reaches slightly more than $20 \mathrm{~mm} \mathrm{dm}$.

The main parawocklumeriid morphological sequence continues (Fig. 7) with the involute but still somewhat open umbilicate Parawo. paprothae. It has been reported from the Rhenish Massif (Clausen et al. 1989a: Müssenberg. endogona Subzone; Becker 1996: Hasselbachtal, late paradoxa Subzone to early sphaeroides Subzone) and the Carnic Alps (Korn 1992a: Grüne Schneid, probably endogona Subzone). A record from Southern Morocco is added here. As mentioned above, the species is also still present as a minor faunal element in the Epiwo. applanata Subzone of Oberrödinghausen. A subtriangular. high, patens-type ventral saddle was illustrated by Becker (1996: pl.2, fig. 12: see also fig. 7). Judging from illustrations in Bogoslovskiy (1981). it seems possible that some material identified as Parawo. laevigata Selwood from the southern Urals in fact belongs to Parawo. paprothae (e.g.. Bogoslovskiy 1981: No. 2688/142. pl. XVI. fig. 10). The same applies to a Parawocklumeria sp. and a Parawo. paradoxa from Kowala figured by Czarnocki (1989: pl. XI. fig. 15. pl. XII. fig. 4). The probable presence of paprothae in Thuringia still needs documentation.

Clausen et al. (1989a) illustrated the relative variable size of the umbilicus in paprothae and it seems difficult to distinguish advanced involute paprothae morphotypes from Parawo paradoxa. There is clearly a gradual transition from $p a-$ prothae, starting in UD $\mathrm{VI}_{-} \mathrm{C}_{1}$. to paradoxa which enters in UD VI- $\mathrm{C}_{2}$. In the definition of Korn, paprothae still includes all very involute forms with narrow triangular slits on the umbilical wall (Clausen et al. 1989a: pl. 4, figs 7. 8, 10. 12) whilst paradoxa has a very small and more rounded umbilical opening (Clausen et al. 1989a: pl. 4. figs 15, 17) which is larger on internal moulds. This difference is not visible in many imperfectly preserved specimens. The stratigraphical overlap of the two forms in UD VI-C 2 and VI-D at Hasselbachtal and Oberrödinghausen proves that they are not parts of a simple chronomorphocline and taxonomic distinction is warranted. but perhaps only at subspecies level. Parawo paradoxa is one of the most common triangular clymenids and reached relatively large sizes (MB.C.1713 from Oese: $27 \mathrm{~mm} \mathrm{dm}$; MB.C.1772.1 from Stiepel: $29 \mathrm{~mm} \mathrm{dm}$ ). More or less equally large Parawo. paprothae occur at Oberrödinghausen (e.g., MB.C.1699.1-2). This supports the idea (compare Korn 1995b) of a hypermorphic trend in advanced parawocklumeriids. Records of Parawo. paradoxa come from the following localities: Rhenish Massif (Wedekind 1918: Burg near Wocklum; Schmidt 1922, det. Wo. distorta, Bilstein; Schmidt 1924, det. Wo. distorta, Oberrödinghausen, Apricke, Höcklingsen. Dasberg, Drewer, Ense = Hauern, Müssenberg: Paeckelmann 1924, det. Wo. distorta, Effenberg. see also Korn \& Luppold 1987; Schindewolf 1937: Langenaubach; Becker et al. 1984: Hasselbachtal; Paproth et al. 1986 and Becker et al. 1993: Oese), Thuringia (Pfeiffer 1954: Bohlen. Bartzsch \& Weyer 1980: Fischersdorf-East). Carnic Alps (Korn 1992b: Grüne Schneid), Holy Cross Mountains (Czarnocki 1989: Miedzianka, Parawocklumeria sp. from Kowala). Silesia (Schindewolf 1937: Dzikowiec), Southern Urals (Bogoslovskiy 1981, det. Parawo. laevigata, Kia), southern Morocco (Korn 1999: Djebel Erfoud), Guizhou, South China (Sun 1964: Taihua: Sun \& Shen 1965: Wangyou, Laowapu: Sheng 1985: Muhua; Sheng in Ji et al. 1989: Dapoushang).

Parawocklumeria laevigata Selwood from SW England (Selwood 1960: Stourscombe, South Cornwall: House 1963: Chudleigh, South Devon) has been put into synonymy of Parawo. paradoxa by Korn (in Clausen et al. 1989a) although it differs from other members of the genus in its much simpler sutures which lack a lobe at the umbilicus (Selwood 1960: fig. 4A, non Parawo. laevigata in Bogoslovskiy 1981). The very low median saddle is very unlike that in Triaclymenia but strongly resembles the juvenile suture of Parawo. paradoxa illustrated by Czarnocki (1989). The new haematitic Parawo paprothae (MB.C.3061, Pl. 4: 7, 8) from Fezzou shows that outer sutures may be influenced by the strong and deep constrictions. One suture running at the bottom of a constriction (Fig. 6b) lacks the 


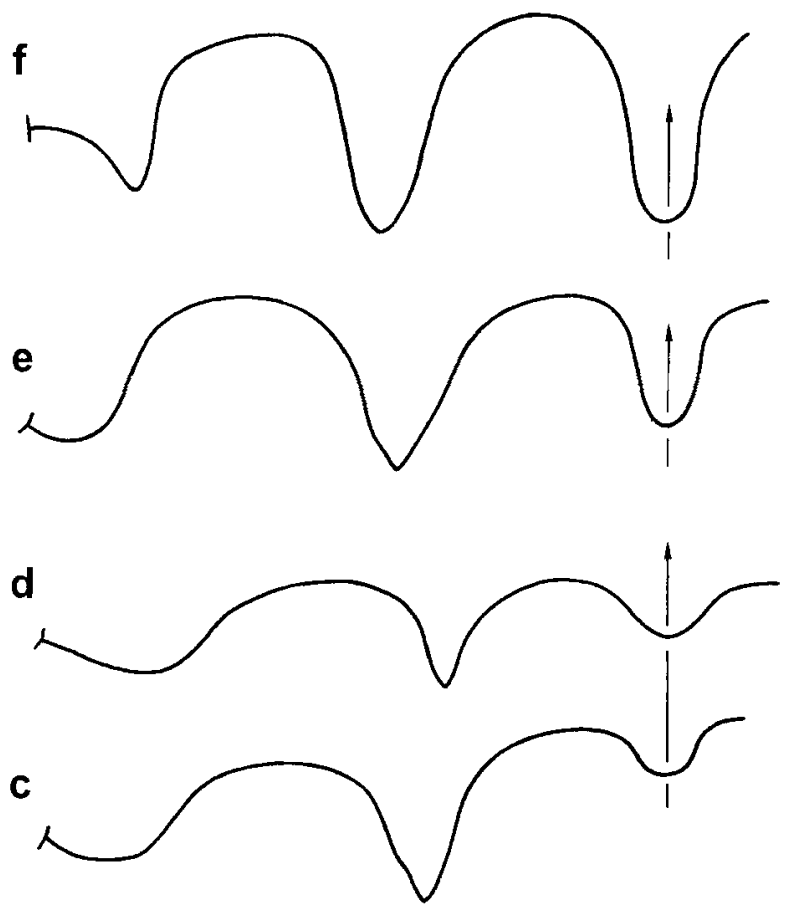

b

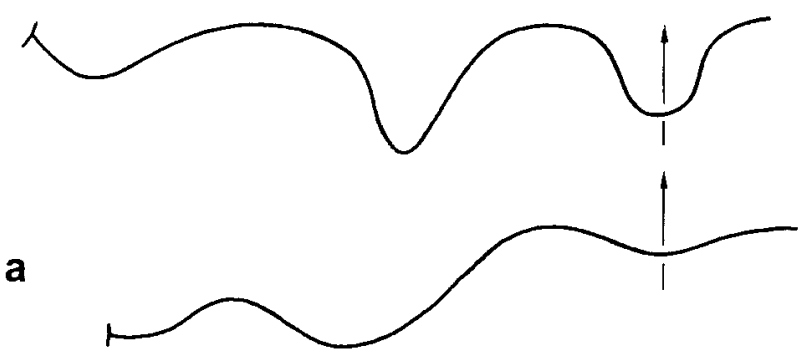

Fig. 8. Sutures of various Wocklumeriidae. a, Tardewocklumeria distributa (after Czarnocki 1989: pl. XLIII, fig. 6c); b, Synwocklumeria mapesi n.sp., MB.C.2706, holotype, at $5.5 \mathrm{~mm}$ wh (ca. $12 \mathrm{~mm} \mathrm{dm}$ ); c, Kielcensia ingeniens n.sp., MB.C, 2705, holotype, at 7.5. wh (ca. $14 \mathrm{~mm} \mathrm{dm}$ ); d, Kielcensic ingeniens n.sp., holotype, same size = other side of specimen, reversed for comparison to show sutural variability; e, Wocklumeria sphaeroides plana, small early rotund morphotype, MB.C.3066 (leg. V. Ebbighausen), at $3.5 \mathrm{~mm}$ wh (ca. $11 \mathrm{~mm} \mathrm{dm}) ; \mathbf{f}$, Wocklumeria sphaeroides sphaeroides, normalsized (triangular) morphotype, MB.C.912, at ca. $6 \mathrm{~mm}$ wh (ca. $15 \mathrm{~mm} \mathrm{dm}$ )

low saddle separating A- and L-lobe and therefore is very close to the one illustrated in laevigata. For this reason, the latter is not seen as an advanced Triaclymenia with closed umbilicus but, as suggested by Clausen et al. (1989a), is placed as an intraspecific variant in Parawo. paradoxa. Support comes from the stratigraphical age: the Stourscombe Beds can confidently be dated as paradoxa Subzone since their lower faunal division (see Selwood 1960) has no evolute Parawocklumeriidae or Glatziellidae but the marker goniatites (Becker 1996) Balvia (Kenseyoceras) nucleus and Balvia (Mayneoceras) biformis which enter at the base of UD VI- $C_{2}$.
Parawo. laevigata var. obesa Selwood is also regarded as a junior synonym of Parawo paradoxa in which there is considerable variability of whorl thickness.

Another strange parawocklumeriid with very small umbilicus from the paradoxa Subzone of Cornwall has been decribed by Selwood (1960) in open nomenclature (Parawocklumeria sp.). Its suture, with very broad saddle occupying all of the flank and small A-lobes bordering a low and weakly developed median saddle, is not comparable with any other involute and triangular form. Current knowledge does not suggest it to be an extreme variant of paradoxa but more material is needed to decide whether it represent a new species.

\section{Evolutionary history and distribution of Wocklu- meriidae}

Fig. 9

\section{Tardewocklumeria n. gen.}

The main apomorphy of the Wocklumeriidae is the presence of median ventral lobes (Fig. 8) which are formed by a shallow to deep and narrow septal fold at the venter. As outlined above, the Wocklumeriidae probably started as a sidebranch from Parawo. distorta (Fig. 7). Tardewo. distributa (Czarnocki) from the paradoxa Zone (probably endogona Subzone) of Kowala (Figs 8 , 9) shares the convolute coiling and a broad flank lobe with distorta, but has a well-developed, widely rounded ventral lobe (Czarnocki 1989: pl. XLIII, fig. 6c, refigured here in Figure 8a). Dorsal sutures have not been described but it is possible that the genus does not yet possess the second I-lobe of all more advanced Wocklumeriidae. According to current interpretation, a lineage of Parawocklumeria-like forms with wide ventral lobes continued to a very involute endmember, Tardewo. perplexa (Bogoslovskiy) which has kept the apomorphic wide and shallow ventral lobe. The species was found associated with Wocklumeria in the Kia Section of the southern Urals. As in parawocklumeriids and in juvenile Synwo. kiense (Bogoslovskiy 1981: fig. 26a), Tardewo. perplexa has a relative widely rounded flank lobe. The inner flank saddle, however, is rather wide as in Synwo. mapesi n. sp. or as in Epiwocklumeria. The alternative, that perplexa descended from involute Synwocklumeria by secondary (paedomorphic) sutural simplification cannot be ruled out completely. 


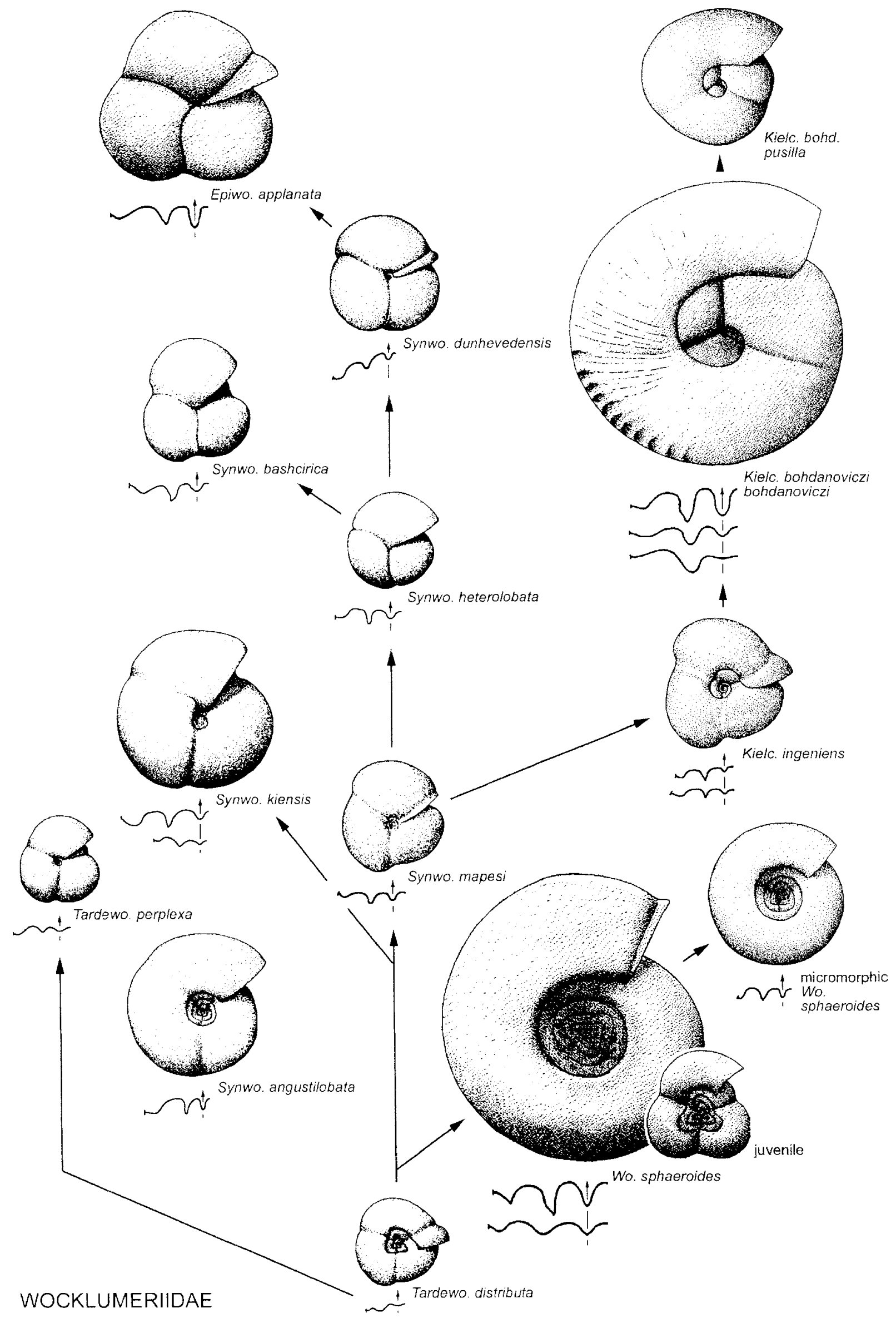

Fig. 9. Morphological series illustrating the reconstructed phylogeny of the Wocklumeriidae. All illustrated specimens in identical magnification $(\times 0.85)$ 


\section{Synwocklumeria Librovich, 1957}

Synwocklumeria differs from Tardewocklumeria n.gen. by the narrow, deep and lingulate to pointed flank lobes, broad and higher inner flank saddle, and by the narrow, small, rounded ventral lobes (Figs $8 b, 9$ ). The sutural formula is the same as in all descendent Wocklumeriidae: $\mathrm{EAL}_{\mathrm{c}}: \mathrm{L}_{\mathrm{i}} \mathrm{I}_{1} \mathrm{I}_{2}$. Epiwocklumeria is distinguished only by its parallel, pointed and very deep ventral lobe and by complete involution (Fig. 9). For this reason, some authors (e.g., Weyer 1981) placed Synwocklumeria in synonymy of Epiwocklumeria. The taxonomic position of Tardewocklumeria is not touched by this discussion. Czarnocki (1989) described from Kowala of the Holy Cross Mountains a range of new wocklumeriids assigned to the new genus Kielcensia. Typical forms around its type (sub)species have involute early stages which abruptly turn into evolute adult whorls. Kielcensia is here restricted to those biform taxa showing the marked change in shell ontogeny. Other species such as $K$. angustilobata, K. mirabilis, and K. heterolobata have triangular, involute shells throughout their known ontogeny and are currently better placed in Synwocklumeria.

An ancestral, still convolute synwocklumeriid would look similar to early stages of Wo. sphaeroides. Such a form (Fig. 9) with still rounded subumbilical lobes and deep lingulate A-lobes has been desribed by Czarnocki (1989) as K. angustilobata. It is well possible that angustilobata is an ancestral representative of Synwocklumeria but substantiation is needed that the species does not develop mature Wocklumeria stages. Synwo. mapesi n. sp. from Morocco (Figs 8b, 9) with small open umbilicus (as in Tardewo perplexa) is the next member in the morphological sequence of the genus. The adventitious flank lobe is still lingulate and the dorsolateral saddle rather wide. Synwo. kiensis Bogoslovskiy from the sphaeroides Zone of Kia (Ural) and the Caucasus (Chegodaev \& Puporev 1979) is rather similar in shell form but the A-lobe is pointed and the lateral saddle rather narrow. The Asian species reaches rather large size $(28 \mathrm{~mm})$ and this may be regarded as a hypermorphic evolutionary trend in comparison with mapesi n. sp. Synwo. bashcirica Librovich from the western slope area of the Urals (Bashkiria) essentially has the same sutures but the flank lobe is inflexed towards the umbilicus which almost closes in adult stages (Fig. 9). These specialisations mark it as an evolutionary sidebranch. Poorly preserved Synwocklumeria have also been reported from the Kozhim area of the northern Timan/Polar Urals (Chermnykh et al. 1988; Nemirovskaya et al. 1993).

Epiwockumeria dunhevedensis Selwood from the sphaeroides Zone of Cornwall (Fig. 9) is moderately compressed and completely involute but has strongly prorsiradiate sutures with a still rather small and narrow ventral lobe. Therefore, the species is better included in Synwocklumeria. K. mirabilis Czarnocki is probably identical with Synwo. dunhevedensis, or at least very close to it. Another completely involute species is Synwo. heterolobata Czarnocki which is said to have very deep and narrow lingulate A-lobes. Morphologically, it is intermediate between Synwo. mapesi n. sp. and Synwo. dunhevedensis (Fig. 9). However, future studies of larger collections may prove sutural variability in synwocklumeriids, and there is perhaps just one variable species with closed umbilicus.

\section{Epiwocklumeria Schindewolf, 1937}

Epiwocklmeria applanata Wedekind (Fig. 9) is seen as an end-member of the Synwocklumeria lineage, characterized by gradual sutural complication, closure of the umbilicus and by the increase in total size. It is mostly distinguished by the further deepening of the ventral lobe, widening of the inner flank-saddle and by strong shell compression. With a maximum diameter of 30-35 mm (Czarnocki 1989), applanata is a larger species than the possibly ancestral Synwo. dunhevedensis or related completely involute species. Obviously there was iterative hypermorphosis in the Wocklumeriidae (Fig. 9). Epiwo. applanata defines the applanata Subzone of the Rhenish Massif (Wedekind 1918: Burg; Schindewolf 1937: Oberrödinghausen; new Hasselbachtal and Drewer records, Pl. 4: 13-16) and occurs as well in the Holy Cross Mountains (Czarnocki 1989). The genus possibly is also present in North America. The specimen described by House et al. (1986) from Rockford (Indiana) differs from juvenile Mimimitoceras by deeper constrictions which do not weaken across the venter. Since the ventral lobe was not observed, the specimen might also represent an involute Synwocklumeria.

\section{Kielcensia Czarnocki, 1989}

The type of Kielcensia, K. bohdanoviczi bohdanoviczi, is characterized by slighty open umbilicate to involute triangular early to median stages 
which abruptly turn into adult. normally coiled and convolute whorls which reach almost $50 \mathrm{~mm}$ in diameter (Fig. 9). Shallow constrictions are still present in the first part of the evolute stage but disappear completely at maturity. It seems that an additional ontogenetic stage was added by hypermorphosis to Synwocklumeria-type median stages (see Korn 1995b). Adult sutures are as in Synwocklumeria in K. bohdanoviczi inaequilobata but have a narrower and deeper ventral lobe in the typical subspecies: the subumbilical lateral lobe remains wide and rounded. An interesting member of the Kielcensia-branch is represented by $K$. bohdanoviczi pusilla. It reaches only $25 \mathrm{~mm}$ in size (Fig. 9) but though possesses a convolute. normally coiled whorl added to small. very involute and triangular early stages. $K$. bohdanoviczi pusilla may have evolved from bohdanoviczi bohdanovic $i$ or in parallel to it, by the re-onset of neoteny which operated at median stages. and which resulted in the suppression of parts of the triangularly coiled whorls. In morphological terms. K. ingeniens $n$. sp. (Figs 8c. d. 9) from southern Morocco is intermediate between Synwo. mapesi n. sp. and advanced Kielcensia. Early stages have a small open umbilicus and the change to subevolute but still triangular adult whorls occurs at relatively small size and not as abrupt as in some Polish Kielcensia specimens. The new species may represent the starting point for a parallel lineage within the genus since a second new form from Oklahoma is hypermorphic as $K$. bohdanoviczi bohdanoviczi but has strongly triangular evolute mature whorls without constrictions.

\section{Wocklumeria Wedekind, 1918}

Wocklumeria is interpreted as an earlier second sidebranch from the main Wocklumeriidae lineage from Tardewocklumeria to Epiwocklumeria which is characterized by corresponding closure of the umbilicus and increasing sutural complication (Fig. 9). Wocklumeria has widely open umbilicate and triangular early stages similar as in Parawo patens and Parawo. distorta. This suggests an origin in convolute synwocklumeriids. As said above, detection of the direct ancestor is hampered by the fact that it would be distinguished from true wocklumeriids only by the lack of their normally coiled adult whorls and probably would be identified as Wocklumeria juveniles. In this circumstance, it is suspicious that faunas from Guizhou have so far only yielded juvenile and triangular specimens, but no normally coiled wocklumeriids.

Selwood (1960) conducted some statistical investigation of wocklumeriids and found no strict distinction between the three species recognized by Schindewolf (1937). Arbitrarily, all three taxa are distinguished at subspecies level (see taxonomic chapter). Adult Wo. sphaeroides (= denckmami Wedekind) reach more than $45 \mathrm{~mm}$ in diameter which is significantly more than the $28 \mathrm{~mm}$ in the largest known Synwocklumeria. The assumption of a hypermorphic evolutionary lineage iteratively to Kielcensia (compare Korn 1995b) seems well justified. However, only a part of youngest Wocklumeria populations is large-sized and in various regions there are, as in Kielcensia, micromorphic specimens reaching only 20 to $25 \mathrm{~mm}$ maximum size. Not adult but median triangular stages seem to have been lost, giving a very special type of intraspecific paedomorphic development (neoteny in a wide sense). This is supported in micromorphic specimens by widely rounded subumbilical lobes (Fig. 8e) as in Synwocklumeria whilst typical Wo. sphaeroides have narrow $L_{e}$-lobes at the same size (Fig. 8f). Further details are given in the taxonomic section.

Wocklumeria sphaeroides is a very abundant clymenid at many German localities: Rhenish Massif (Wedekind 1914: Burg = Borkewehr near Wocklum, det. Wo. denckmanni; Wedekind 1918: $\mathrm{N}$ of Nuttlar, det. Wo. denckmanni; Schmidt 1924: Hasselbachtal, Apricke, Oberrödinghausen, Dasberg, Trachtenberg; Schindewolf 1926: Drewer: Gallwitz 1927: Höcklingsen; Schmidt 1927 and Clausen et al. 1979: Bilstein Valley; Paeckelmann 1932: Aske; Schmidt 1933: Braunau. Kellerwald; Weber 1934: Grimminghausen; Korn 1981: Müssenberg; Paproth et al. 1986 and Becker et al. 1993: Oese; Luppold et al. 1994: Hangenberg. Eulenspiegel), Thuringia (Pfeiffer 1954: Bohlen. Wo. sphaeroides sphaeroides and sphaeroides plana; Schindewolf 1937: Leutenberg. Probstzella Railway Station; Bartzsch \& Weyer 1980. 1982: Fischersdorf-East, with all three subspecies, Fischersdorf-West, Gleitsch Railway Cut, Mühltal near Obernitz; Bartzsch et al. 1995: Kahlleite-East). Further records are from Cornwall (Selwood 1960: Stourscombe Quarries. ?Overwood Farm; Whiteley 1981: ?Viverdon Down Trenches), the Armorican Massif (Peneau 1929: St. Juliens-de-Vouvantes), perhaps the Montagne Noire (Flajs \& Feist 1988: La Serre. det. Wocklumeria sp.; Korn 1993: Col de Puech de la Suque), southern Morocco (Hollard 
\& Jacquemont 1956: Jebel Aguelmous, cf. Wocklumeria, confirmed by new material, leg. S.Z. Aboussalam; Korn 1999: Mrakib; new record from Fezzou), Southern Algeria (Petter 1954, 1960: all three subspecies at Marhouma), the Carnic Alps (Korn 1992a: Grüne Schneid), the Holy Cross Mountains (Czarnocki 1989: Miedzianka, Kowala), the Urals (Bogoslovskiy 1981: Kia), Guangxi (Yu et al. 1987 and Ruan 1988: Nanbiancun; Gong et al. 1985: ?Zaisha), and Guizhou (Sun 1964: Taihua = Daihua; Sun \& Shen 1965: Laowapu, Wangyou). Breitkreuz (1986) reported a wocklumeriid from Chile but so far only field observations have been made and the fate of material is unclear (oral. comm. H. Bahlburg, Münster).

\section{Origin of the Wocklumeriaceae and systematic relationships}

\section{The Hexaclymeniidae as possible ancestors of the Wocklumeriaceae}

Since the times of Schindewolf (1937), no direct ancestor of Wocklumeriaceae has been recovered from strata just below their earliest occurences in the upper Wocklum-Stufe anywhere in the world. The ancestry of the superfamily, therefore, has to be inferred from morphological comparison and from the identification of common characters (synplesiomorphies) with other, older clymenid groups. The evolutionary history has to be deduced from ontogenies and the successive appearance of morphological innovations in time.

\section{Comparison of Wocklumeriaceae and Hexaclymeniidae}

The sutural ontogeny of the most primitive member of the superfamily, Kampto. endogona, shows (Fig. 5a) that ventral and median saddles are not yet present in juveniles. The juvenile sutural formula is simply EA:I. This is basically the pattern found in all genera of the Hexaclymeniidae (Fig. 10e).

The species identification of triangular clymenids is often complicated by the lack of visible sutures. This simply reflects the fact, well-known also from longitudinal sections (e.g., Schindewolf 1937, Czarnocki 1989), that the body chambers reaches much more than a full whorl. In convolute to involute taxa it covers all or most parts of the phragmocone. Already Trueman (1941) outlined the fundamental significance of the body chamber length for shell orientation and paleoecology. During life, the aperture of all Wocklumeriaceae was oriented downwards to the substrate (see examples in Fig. 1) which suggests bottom-feading and demersal (suprabenthonic) lifestyle. Such autecological interpretation is supported by the common reduction of the lateral (ocular) sinus of the growth lines and aperture which is seen as a measure for the protection of the soft-body against benthic predators such as various arthropods.

Schindewolf's idea of phylogenetic relationships between wocklumeriids, parawocklumeriids and Hexaclymeniidae is supported by the long
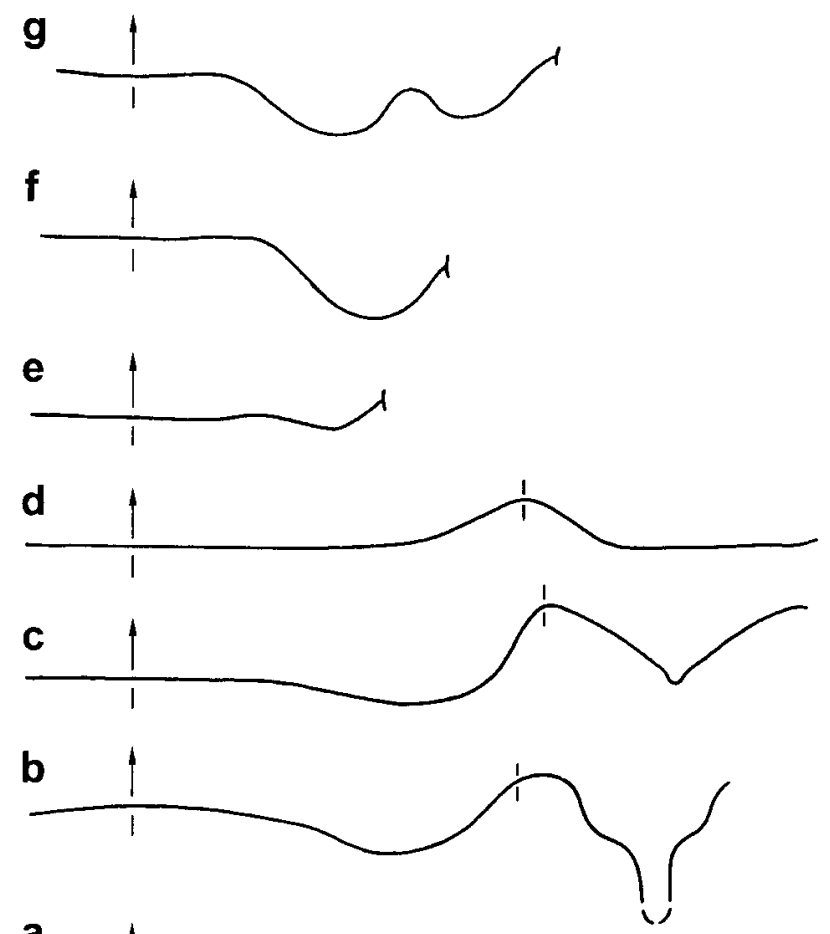

a

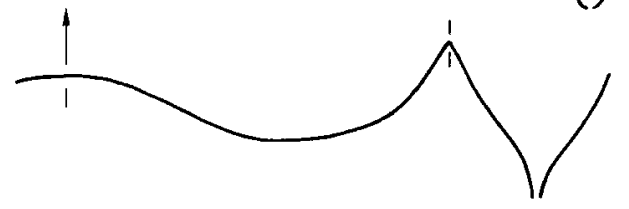

Fig. 10. Sutures of depressed Platyclymeniidae, various Hexaclymeniidae and of Trochoclymenia. a, Platyclymenia (Varioclymenia) pompeckji, after Perna (1914: text-fig. 72), UD IIIC; b, Platyclymenia (Varioclymenia) pompeckji, MB.C.1729 (= Oc 575), Nie Brickwork Quarry, Bed 7 (delphinus Zone, UD III-C), at $7 \mathrm{~mm}$ wh (ca. $30 \mathrm{~mm} \mathrm{dm}$ ); c, 'Pleuroclymenia' americana, MB.C.1734.1, Threefork Shale, Montana, UD IV-A, leg. RTB in 1987 , at ca. $5 \mathrm{~mm}$ wh; d, Pleuroclymenia costata, topotype of 'Platy. crassissima', MB.C.1266, Kirchhofen, annulata Zone (UD IV-A), at ca. $17.5 \mathrm{~mm} \mathrm{dm}$ (ca. $6 \mathrm{~mm}$ wh); e, Hexactymenia hexagona, MB.C.1805.2, Enkeberg, delphinus Zone (UD III-C), at $3.5 \mathrm{~mm}$ wh (ca. $13 \mathrm{~mm}$ $\mathrm{dm}$ ); f, 'Clymenia' nana, MB.C.3062, Jebel Aguelmous, Maïder, leg. V. Ebbighausen, UD V-A, at $10.5 \mathrm{~mm} \mathrm{dm}$; g, Trochoclymenia wysogorskii, MB.C.3065, original of Schindewolf (1937: 24), Ebersdorf (Dzikowiec), at $25 \mathrm{~mm} \mathrm{dm} \mathrm{(5} \mathrm{mm} \mathrm{wh)}$ 
body chambers of the latter [see, e.g., median section of Progonioclymenia acuticostata (Münster) in Bogoslovkiy 1981], by the long septal necks both in the Parawocklumeriidae and in genera of the Hexaclymeniidae (Schindewolf 1937, Bogoslovskiy 1976), and by the typical shell form with broad, depressed. very slowly expanding whorls. Of course, there is a strict functional relationship between body chamber length and low whorl expansion rate. Neutral buoyancy required for a functional hydrostatic apparatus gives upper limits for the ratio between body chamber and phragmocone volumes. Throughout growths. there has to be a balance between body + shell weight and the positive buoyancy of gas chambers. Broad whorl profiles, however, can be formed independently from changes in expansion rates by co-variation between whorl and umbilical width (Becker 1993a. Checa et al. 1996).

It has been questioned (Korn 1992b) whether the Hexaclymeniidae, defined by their EA:I sutures, form a valid systematic group at all. Ventral lobes of clymenids have to be seen in conjunction with the trend to develop flat and tabulate venters (Schindewolf 1937: Korn 1992b: e.g., in Stenoclymenia and Pricella). Septal folds ("true lobes") may be distinguished from shallow and rounded lobes ("pseudolobes" sensu Schindewolf 1937: 54) created by the intersection of the curved septum by a flat outer shell wall. If "pseudolobes" (and therefore shell form) characterize a lineage, sharing perhaps in addition other conch features, this, of course, can be used as synapomorphy in taxonomic definitions. Korn's (1992b) dissolution of the Hexaclymeniidae is rejected here. His placing of hexaclymeniid genera in three different and unrelated families is in conflict with suture and shell characteristics. In addition. within the family, morphological and stratigraphical intermediates between genera are known whilst an iterative origin of members is not supported by intermediates to clymenids of other families. Hexaclymenia differs, for example, from all Cyrtoclymeniidae by their very short septal necks. shorter body chambers and by the different shape of the dorsal lobes in the latter. Progonioclymenia superficially resembles ribbed and evolute Platyclymeniidae but these are mostly brevidomic, compressed, and have very deep, narrow and parallel dorsal lobes. Relationships with certain intermediate mesodomic and depressed platyclymenids will be discussed later. Soliclymenia is very similar to Progonioclymenia (Weyer 1981.
Price \& Korn 1989) and is perhaps an ancestor of the Glatziellidae, but still lacks their apomorphies: the divided ventral lobe (Fig. 11b) and the pronounced keel. Therefore, it cannot be placed in the Glatziellidae.

The ventral lobe of some Hexaclymeniidae also cannot be explained by their cross-sections alone. Soliclymenia displays a shallow ventral lobe despite a gently curved and not tabulate venter (e.g., Bogoslovskiy 1981: fig. 5d) whilst 'Pleuroclymenia' americana (Raymond) and Platyclymenia pompeckji Wedekind with similar wide and flatly rounded venter have low ventral saddles instead of a wide lobe (Miller 1938, Perna 1914; see Fig. 10a-c). Due to the lack of appropriately preserved material, septal faces have not yet been studied in most Hexaclymeniidae but it has to be remembered that the radius of septal curvature is as important as the cross-section for the course of sutures.

\section{Gyroclymenia Czarnocki, 1989 and Pleuroclymenia Schindewolf, 1934}

The three-ribbed hexaclymeniid genera discussed above cover stratigraphically the Famennian III to VI (Fig. 4) but are too dissimilar to be close relatives of the smooth and constricted Kamptoclymenia. Czarnocki (1989) added Gyroclymenia as a fourth genus. It embraces a range of evolute, strongly to weakly ribbed species with characteristic ventral constrictions, wide dorsal lobe, shallow rounded lateral lobe, and broad and shallow ventral lobes which is sometimes not seperated from the flank lobe (Fig. 10e). Representatives of this group occur not only in Poland but also widely in the UD III-C to IV-B of the Rhenish Massif (e.g., Kattensiepen, Warstein region; MB.C.1732 from the Nie Brickwork Quarry, northern Sauerland; specimens from the Hauern, Kellerwald, MB.C.1806.1-6; see Pls 1, 2). All species of the genus are longidomic.

The so far unfigured holotype of Pleuro. crassissima (Schindewolf 1955; = Platy. crassa Schindewolf, 1923a, non Platy. quenstedti var. crassa Schindewolf, 1923a; Marburg University collection. No. 3154) is ribbed until late stages (ca. $37 \mathrm{~mm} \mathrm{dm}$ ) and also has characteristic deep constrictions as well as very wide and shallow ventral lobes. Gyroclymenia clearly is a subjective junior synonym of Pleuroclymenia. A Berlin topotype (MB.C.1266) from the annulata Zone of Kirchhofen near Weilburg (southern Rhenish Massif) turned out to be congeneric with Gyroclymenia 
Table 2

Dimensions of various Pleuroclymenia species.

\begin{tabular}{|c|c|c|c|c|c|c|c|c|c|}
\hline species/specimen. & $\mathrm{dm}$ & uw & wh & ah & ww & uw\% & Ww \% & $a h \%$ & wh/ww \\
\hline \multicolumn{10}{|l|}{ kasachstanica } \\
\hline MB.C.1731 & 29.5 & 13.8 & 8.8 & \multirow[t]{2}{*}{6.7} & 11.1 & 46.8 & 37.6 & \multirow[t]{2}{*}{22.7} & 0.8 \\
\hline MB.C.1731 & 23.2 & 11 & 6.9 & & 10.3 & 47.4 & 44.4 & & 0.67 \\
\hline \multicolumn{10}{|l|}{ costata } \\
\hline Marburg 3154 & ca. 37 & 16.3 & 12.2 & \multirow{7}{*}{$\begin{array}{l}4.5 \\
3.8\end{array}$} & 16.6 & 44.1 & 44.9 & \multirow{7}{*}{$\begin{array}{l}23.7 \\
25.3\end{array}$} & 0.73 \\
\hline MB.C.1266 & 19 & 8.7 & 5.8 & & 10.4 & 45.8 & 54.7 & & 0.56 \\
\hline MB.C. 1266 & 15 & 6.6 & 4.7 & & 8 & 44 & 53.3 & & 0.59 \\
\hline MB.C.1266 & 11.5 & 5.3 & 3.3 & & ca. 6.8 & 46.1 & ca. 59 & & ca. 0.5 \\
\hline MB.C. 1806.3 & 9.1 & 4 & 2.8 & & 5 & 44 & 61.5 & & 0.56 \\
\hline MB.C.1806.5 & 7 & 3 & 2.3 & & 4 & 42.9 & 57.1 & & 0.58 \\
\hline MB.C. 1806.6 & 5.8 & 2.6 & 1.8 & & 3.6 & 44.8 & 62.1 & & 0.5 \\
\hline \multicolumn{10}{|l|}{ cyclocostata } \\
\hline MB.C.1732 & 41 & 21.6 & 10.7 & \multirow[t]{2}{*}{ ca. 8.5} & 14.4 & 52.7 & 35.1 & \multirow[t]{2}{*}{ ca. 20.7} & 0.74 \\
\hline MB.C.1732 & 33.8 & 17.8 & 8.9 & & ca. 13 & 52.7 & ca. 38.5 & & ca. 0.7 \\
\hline \multicolumn{10}{|l|}{ mutabilis } \\
\hline MB.C.1807.1 & 16.8 & 7.3 & 5 & \multirow[t]{3}{*}{4} & 8 & 43.5 & 47.6 & \multirow[t]{3}{*}{23.8} & 0.63 \\
\hline MB.C. 1807.2 & 16.2 & 8.2 & 4.3 & & 8 & 50.6 & 49.4 & & 0.54 \\
\hline MB.C. 1807.3 & 14 & 5.7 & 4.7 & & 6 & 40.7 & 42.9 & & 0.78 \\
\hline
\end{tabular}

as well. The specimen has been discussed and synonymized with crassissima by Schindewolf (1924: 100) himself. As outlined by Lange (1929), the topotype is also identical with ?Cycloclymenia costata Lange which becomes an older subjective synonym. The valid identification of the Pleuroclymenia type species, therefore, is Pleuro. costata (Lange). Unfortunately, Lange's type of costata could not be traced in the remains of his collection in the Museum für Naturkunde and in the Geological Institute of Hamburg University (oral. comm. W. Weitschat 1998).

A purchased topotype (?syntype, MB.C.1731) confirms that Platyclymenia kasakhstanica Kind, 1944 from the Mugodzhar Mountains possesses the typical ventral constrictions and long body chamber of Gyroclymenia. This species, interestingly, is completely smooth apart from earliest whorls. Platy. Quenstedti var. crassa Schindewolf (1923a) may represent another smooth species with broad, kidney-shaped cross-section, but it has never been illustrated and, therefore its generic assignment is open. Pleuro. sophiae (Czarnocki) also lacks ribs but is more involute than kasachstanica. Smooth pleuroclymenids may belong to the so far undocumented lineage leading to Kamptoclymenia but in terms of time (Fig. 12) and morphology there is still a rather wide gap between both.

\section{Homoeomorphs and ancestors of Pleuroclymenia}

The revision of Pleuroclymenia as member of the Hexaclymeniidae in the future requires a

generic re-assigment of the mesodomic Pleuro. americana Group which lacks constrictions and which has shallow dorsal lobes but low ventral saddles (see Schindewolf 1934 and Miller 1938; topotypes MB.C.1734.1-3, leg. RTB 1987; collection of the University of Iowa City: SU I 12277 etc.). Other species assigned to Pleuroclymenia, such as Pleuro. eurylobica Petersen and Pleuro. ohioense House et al., as well as Clymenia lagowiensis Sobolev, Platy. (Platy.) inflata Czarnocki and Cyrtoclymenia enkebergensis var. crassa Petter (non crassa Wedekind), represent a thickwhorled and subinvolute side-branch of unrelated Protactoclymenia (Cyrtoclymeniidae) with concavoconvex growth lines. According to shell morphology (wide umbilication, ribbing, broad, depressed whorls, mesodomic body chamber) and stratigraphical range (UD III-C, Prolobites delphinus Zone), the ribbed Platy. pompeckji Group was the phylogenetic link (Fig. 12) between Pleuroclymenia and the brevidomic Platyclymeniidae (Clymeniina, Clymeniaceae). The pompeckji Group is characterized by rather deep dorsal lobes as in typical Platyclymenia (Fig. 10a, b). Platy. pompeckji was designated by Matern (1931) as the type-species of Varioclymenia Wedekind which was followed by Nalivkina (1953). The taxon is used here as a subgenus of Platyclymenia lacking parabolic ribs and with whorls that are as wide as or wider than high at median to adult stages. In this definition, Platy. (Varioclymenia) includes a range of taxa from the Prolobites delphinus Zone (UD III-C) of Germany (see Pl. 1: 1-7), the Urals and of the Mugodzhar Mountains: 
- Clymenia annulata var. correcta Perna. 1914 (probably = Cl. placida)

- Clymenia brevicostata Münster. 1842 (e.g. MB.C.1735. PI. 1: 5-6 und MB.C.1763. leg. Paeckelmann. from Enkeberg. Beds 8 and 9 - type material should be at Bayreuth)

- Platyclymenia (Variocilmenia) callimorpha Lange. 1929 (probably a subspecies of cycloptera)

- Clymenia cycloptera Wedekind. 1908 [House 1970 re-illustrated Wedekind's original of plate 43. fig. 11 as holotype. However. Wedekind had reported two specimens and did not select a type. Hence. the twice figured specimen has to be called lectotype.]

- Platyclymenia humilis Schindewolf. 1934 (= brevicosta Wedekind, 1908, nom. vad.: e.g. MB.C.1736. Pl. 1: 7. sce Becker 1985: fig. 3a. Nie Brickwork Quarry)

- Clymenia placida Perna. 1914

- Clymenia (Varioclymenia) pompeckii Wedekind. 1908 (nom. corr.: pompeckji. e.g.. MB.C.1729. Pl. 1:1. 2. and MB.C.1737 = Oc 575 from the delphimus Zone of the Nie Brickwork Quarry: MB.C.1730. leg. RTB 1985, from Enkeberg. see Pl. 1: 3. 4)

- Platyclymenia (Variochmenia) pompeckji var. decora Kind. 1944 (probably a subspecies or morphotype of brevicostata Münster)

- Platyclymenia (Variod lmenia) pompeckji var. kasakstanica Nalivkina. 1953 (non Vario. kasachstanica Kind. 1944: invalid homonym; probably a subspecies or morphotype of brevicostata Münster)

- Platyclymenia (Varioclymenia) pompeckji var. senilis Lange. 1929 (subspecies of cycloptera)

- Platyclymenia (Varioclymenia) transita Kind. 19.4 (probably identical with callimorpha)

There is clearly taxonomic oversplitting in Varioclymenia and the study of larger populations will show which of the names should be kept. The genus is perhaps also rarely present in unpublished collections from Southern Morocco. Since a platyclymenid-type dorsal lobe has only been illustrated in Platy. (Vario.) pompeckji (Perna 1914, re-illustrated in Figure 10a), it cannot be ruled that some of the listed forms belong to the 'Pleuro.' americana Group with shallow dorsal lobes. A pompeckji fragment from the Nie Brickwork Quarry (MB.C.1737 = Oc 575, Fig. 10b) shows dorsal sutures with moderately wide. pointed and deep lobes, which are. related to the broad concave whorl part, not quite as narrow as in Platyclymenia (Platyclymenia).

\section{Evolution of the Hexaclymeniidae}

At a very early stage in clymenid evolution (early Prol. delphinus Zone, UD III-C), slowly expanding varioclymenids which still have tornoceratid-type dorsal lobes, depressed whorl profile and increased body chamber length obviously gave rise to the oldest and ribbed pleuroclymenids (Figs 10, 12). These developed constrictions as an adaptive measure to protect the vulnerable soft parts against benthic predators behind a more rigid apertural margin. At the same time. dorsal lobes became shallow and incipient ventral lobes formed. The youngest Pleuroclymenia are known from the Protoxyclymenia dunkeri Zone (UD IV-B) of the Rhenish Massif (Becker 1997a) and from similar levels of the Holy Cross Mountains (Czarnocki 1989) and of the famous Kia Section in the southern Urals (Bogoslovskiy in Simakov et al. 1983; see Fig. 4). The oldest and moderately small (max. $23 \mathrm{~mm} \mathrm{dm}$ ) Soliclymenia entered probably at about this time in the Urals (Bogoslovskiy 1981) and perhaps in the Carnic Alps (Price \& Korn 1989). The morphological step from evolute and ribbed Pleuro. evoluta (Czarnocki) to extremely evolute soliclymenids with deeper ventral lobes was rather small. Members of the pleuroclymenid ancestor group, especially Platy. (Vario.) humilis (e.g., MB.C.1736, see Pl. 1:7), developed iteratively similar conches as in Soliclymenia.

From the oldest and still poorly documented soliclymenids of the higher part of UD IV it was only another small step to large-sized (up to $50 \mathrm{~mm} \mathrm{dm}$ ) and more compressed Progonioclymenia of UD V-A/B (Figs 4, 12), characterized by a rimmed, flat or grooved venter. Species of Progonioclymenia differ from each other in the shape of the venter, their ornament, and by the development of ventrolateral spines in the typespecies (Schindewolf 1937, Price \& Korn 1989). A fragmentary assemblage from Ballberg near Hövel (MB.C.1756.1-21, Bed 3, leg. Schindewolf in 1931), which also yielded the neotype of Progonio. acuticostata (Münster), shows that there is more intraspecific variability than previously recognized. Ribbing varies from recti- to prorsiradiate and from straight to slightly concave. The same applies to collections from the Kellerwald (leg. Denckmann in 1893-1897: MB.C.3063.1-2, 3068.1-2, 3069, leg. Schwalm in 1902: MB.C.3070.1-3). Ribs disappear at a marginal spiral rim (Pl. 2: 9, 10) and the ventral furrow appears late in ontogeny ( $\mathrm{Pl}$. 2: 8). Spines have not been observed and early whorls are smooth. Currently, the more common Rhenish form is assigned to Progonio. aegoceras (sensu Price \& Korn 1989). Soliclymenia and Progonioclymenia have roughly the same geographical distribution as Pleuroclymenia but both do occur in the Carnic Alps.

Soliclymenia must have survived during the Famennian $\mathrm{V}$ in some region to give rise by some paedomorphic change (Korn 1995a, b) to smaller-sized ( $\max c a .17 \mathrm{~mm} \mathrm{dm}$ ) species of the lower Wocklum-Stufe (Fig. 12). In this youngest hexaclymenid lineage, triangular coiling (Soli. 
paradoxa) developed as an iteration to the Wocklumeriaceae (Fig. 4). Homoeomorphism occurs in completely unrelated groups. Triangular coiling re-appeared, as an example, again in much later Carboniferous goniatites (Croneis 1930). Though, it is rather common that identical selective processes lead to similar morphological features in genetically close taxa, a phenomenon described as mosaic evolution. Therefore, the invention of triangular whorls in advanced soliclymenids, rather than in any other clymenid group, seems to support (but, of course, does not prove) relations between Hexaclymeniidae and Wocklumeriaceae.

Hexaclymenia hexagona (Wedekind) is thought to represent an early smooth to slightly ribbed, keeled side-branch from Pleuroclymenia (Fig. 12) with unusual spiral striae that are obviously only visible on well-preserved specimens. Adult whorls expand somewhat faster than in other members of the family (Pl. 2: 5, 6). Wedekind (1908) reported six specimens and did not select a type. Therefore, his original of plate 43 , figs $7,7 \mathrm{a}$, should not be called holotype (House 1970, with re-illustration) but lectotype. This, so far, monotypic genus ranged from the delphinus Zone (UD III-C) perhaps into younger strata (Renz 1914; Schmidt 1924: "oberer Clymenienkalk", ?UD V; Sanz-Lopez et. al. 1999: well above Annulata Event, UD IV-B). As other members of the family, it is known from Germany, Poland, and Russia. Specimens leg. by Lotz \& Denckmann in 1900 (MB.C.1805.1-6) show that the ventral lobe is much shallower than illustrated in Schindewolf (1923b). In MB.C.1805.3 (Fig. 10e), a wide and flat ventral lobe is almost continuous with the shallow flank lobe, resembling sutures in some Pleuroclymenia (Fig. 10d) and in small Kamptoclymenia (Fig. 5a). A deep ventral lobe was only artificially produced by grinding too strongly. The new observations may explain why Perna (1914: fig. 74) has not shown any ventral lobe at all in a Ural specimen. According to Perna, the dorsal lobe is relative wide as in other Hexaclymeniidae.

Keeled clymenids (MB.C.1733 = Oc 488, MB.C. $1734=$ Oc 770) assigned to Hexa. hexagona from the lower part of the delphinus Zone of the Nie Brickwork Quarry (Becker 1985) differ in their strong shell compression and weak radial ornament on the lower flank. Sutures are not preserved but both specimens are more likely to belong to the poorly known Genuclymenia guembeli (Wedekind).

\section{Origin of the Wocklumeriaceae}

Known smooth pleuroclymenids are not evolute enough to include a possible direct ancestor of Kamptoclymenia. However, there is a long overlooked small-sized clymenid from UD V which is more similar in showing marked constrictions, and a flattened venter with very shallow ventral lobes (Fig. 10f): Clymenia nana Münster. As suggested by D. Korn (in press), the species has to be placed in a new genus. It occurs in Germany as well as in the Carnic Alps (D. Korn, written comm.) and rarely in the Tafilalt and Maïder of southern Morocco (e.g., MB.C.3062, leg. V. Ebbighausen, Pl. 3: 1, 2). At the Jebel Aguelmous and in the southern Tafilalt (Jebel Ouaoufilal), the typical level is very low in the Dasberg Stufe (regional Endosiphonites muensteri Zone, Becker et al. 1999). Kamptoclymenids have wider whorls than 'Clymenia' nana as well as shallower flank lobes (Fig. 6a), but at present the latter is a candidate for phylogenetical relationships (see Fig. 12).

Another rather enigmatic genus with very similar, extremely evolute and smooth shell from the lower Wocklumeria Stufe is Trochoclymenia. The genus occurs rarely in Silesia but, as mentioned above, a single similar, poorly preserved and roughly contemporaneous specimen has been described by Becker (1988) from Hasselbachtal. The older (lower UD V, not IV) North African Trocho. ornata Petter (lectotype here designated as original to her plate III, fig. 7) is a close relative of Endosiphonites muensteri and not related to Trocho. wysogorskii (Frech). The latter has two rounded flank lobes as in Kamptoclymenia, but the outer, not the inner flank lobe is deeper (Fig. 10g). According to Schindewolf, the probably lost holotype has a deep dorsal lobe as in the Platyclymeniidae. Furthermore, constrictions are lacking. Preparation of a second specimen from Dzikowiec (MB.C.3065) described by Schindewolf (1937: 24) showed that sutures are similar to Frech's type and Schindewolf's suture illustration (his figure 3 ) is regarded as doubtful. Trochoclymenia reaches more than $50 \mathrm{~mm}$ dm which is larger than both 'Clymenia' nana and Kampto. endogona. With respect to the shell form and to the long gap between other Platyclymeniidae and Trochoclymenia, it is possible that Trochoclymenia was derived from 'Clymenia' nana and that it represents a parallel Igroup to Kamptoclymenia with extra umbilical lobes. Unfortunately, available specimens (Berlin, third topotype of Czarnocki 
1989) do not show dorsal sutures and no final judgement is currently possible. Lewowicki (1959) failed to re-collect the species at the type locality. It should be noted, however, that the earliest whorls in Czarnocki's specimen appear to be somewhat polygonally coiled.

\section{Systematic relationships of the Wocklumeriaceae}

Glatziellaceae n. superfam.

(nom. transl. herewith from Schindewolf 1928)

Soliclymenia may have given rise to evolute and ribbed glatziellids which share the slowly ex-
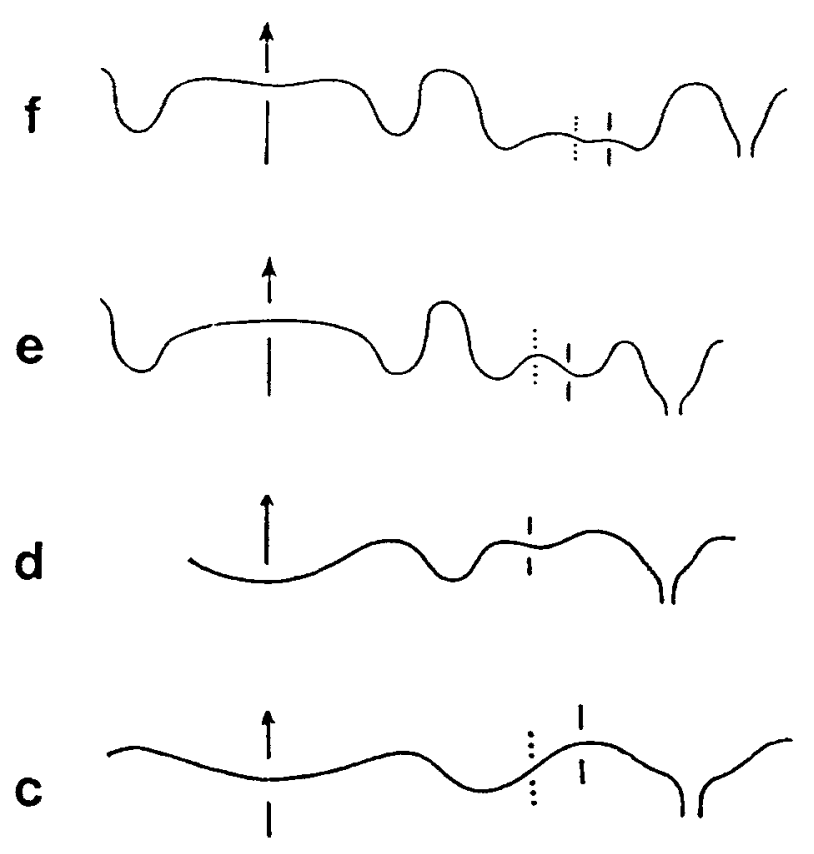

b

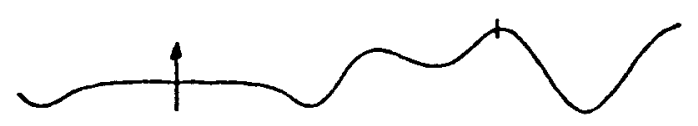

a

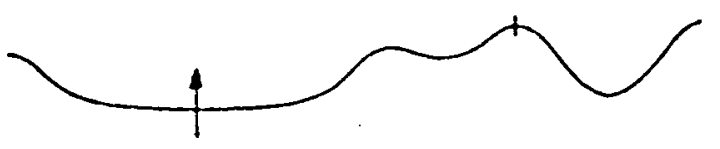

Fig. 11. Sutures of Glatziellidae and Biloclymeniaceae. illustrating the iterative formation of wide ventral saddles in both families. a, Glatziella helenae (Glatziellidae. after Schindewolf 1937: fig. 15a). juvenile stage: b, Glatziella helenae (Glatziellidae. after Schindewolf 1937: fig. 15b). adult stage: c. Uraloclymenia volkovi (Pachyclymeniidae. after Bogoslovskiy 1981: fig. 13b) at $18 \mathrm{~mm} \mathrm{dm}(6.7 \mathrm{~mm}$ wh): d, Pachyclymenia intemedia (Pachyclymeniidae. after Bogoslovskiy 1981: fig. $15 \mathrm{a}$ ). at ca. $30 \mathrm{~mm}$ dm: e, Kiaclymenia semiplicata (Biloclymeniidae. after Bogoslovskiy 1981: fig. 18c), at ca. $10 \mathrm{~mm}$ wh: f, Biloclymenia aktubensis (Biloclymeniidae, after Bogoslovskiy 1981: fig. 19b), at ca. $24 \mathrm{~mm} \mathrm{dm} \mathrm{(12} \mathrm{mm} \mathrm{wh)}$ panding and longidomic whorls but which developed pronounced keels and which divided the ventral lobe at late ontogenetic stages (Fig. 11a, b). Becker (1997a), however, described a much earlier (UD IV-B) smooth glatziellid which is here assigned with a query to the genus. The spiral rim bordering the venter of Progonioclymenia (Pl. 2: 9, 10) also can be interpreted as an incipient keel. At present, the origin of Glatziellidae is not yet clarified. The group developed iteratively the same outer sutures as the smooth kamptoclymenids (compare Fig. 5b with 11b) but the dorsal lobe remained undivided (Schindewolf 1937). Advanced glatziellids became narrow umbilicate and goniatite-like (Glat. glaucopis Renz, Postglatziella; Fig. 4) which parallels evolutionary trends in the sister taxon Wocklumeriaceae. Sinoglatziella has been placed in synonymy with Glatziella (Becker 1997a). Glat. glaucopis reaches larger sizes than other members of the group (Becker 1997a) which can be seen as yet another iterative hypermorphic trend in the Wocklum Stufe. Longidomic Hexaclymeniidae and descendent glatziellids can be combined in a systematic unit with wide and simple dorsal lobe and lacking constricted, triangularly coiled ontogenetic stages (compare Weyer 1981: 9). For priority reasons of existing family-level taxa, this new superfamily is named as Glatziellaceae $\mathbf{n}$. superfam.

\section{Gonioclymeniina Schindewolf, 1923a, Sellaclymeniaceae Schindewolf, 1923a, and Gonioclymeniaceae Hyatt, 1884}

In traditional clymenid systematics, the suborder Gonioclymeniina (nom. transl. from Gonioclymeniaceae of Schindewolf 1923 a by Ruzhencev 1957) embraced all forms with ventral lobe. Bogoslovskiy (1981), House (1981), and Bogoslovskaya et al. (1990) followed Schindewolf's (1937, 1955) phylogenetic concepts and recognized the superfamilies Sellaclymeniaceae (including the Hexaclymeniidae and Wocklumeriidae; supposedly without adventitious lobes), Gonioclymeniaceae (with A-lobes) and Parawocklumeriaceae. Korn (1992a) and Becker \& Kullmann (1996) recognized the significance of intermediate triangular clymenids between Parawocklumeriidae and Wocklumeriidae, and consequently combined both families in a superfamily Wocklumeriaceae. The family level taxon Wocklumeriidae has "page priority" to Parawocklumeriidae in Schindewolf (1937). 
Without discussion, Korn (1992a) also eliminated the distinction between the (remaining) Sellaclymeniaceae and Gonioclymeniaceae which is followed here. It has to be emphasized that all clymenids posses an adventitious mid-flank lobe which they inherited from their tornoceratid ancestors (House 1970, Becker \& Kullmann 1996). Sutural simplification resulted in the reduction of the lateral lobe at the umbilicus and in the shortening of the outer subumbilical saddle as it is known iteratively in tornoceratid groups such as Planitornoceras (Becker 1995). This trend led to most simple-lobed forms such as Cyrtoclymenia and Platyclymenia but their primitive septal shape is a derived character. Sutural patterns in ammonoids generally followed strict genetical programs. Although the shape of the single midflank lobe in many clymenids is (secondarily) to a large extent controlled by cross-section (Westermann 1975, Korn 1992a), the "pseudolobe" or flank part of any clymenid septum was still secreted as in tornoceratids by the "adventitious part" of the epithelium. Subsequent returns from "pseudolobes" to shallow "true" mid-flank lobes probably involved the re-activation of episodically supressed genetical data. The clymenid midflank lobe always should be called A-lobe but it seems useful to mark if there are "true" septal folds. The probably heterochronic re-appearance of shallow lobes in umbilical position (e.g., in Parawocklumeria; Fig. 5e) similarly can be interpreted as a return of lateral lobes by mid-ontogenetic unblocking of disused genom parts.

\section{Origin of the Gonioclymeniaceae}

Czarnocki (1989) described from the Holy Cross Mountains the genus Nodosoclymenia which combines in species such as Nod. pseudobiimpres$s a$ Czarnocki simple platyclymeniid sutures with gonioclymeniid growth ornament which is almost straight and rectiradiate or prorsiradiate on the flanks. Evolute and moderately fast expanding

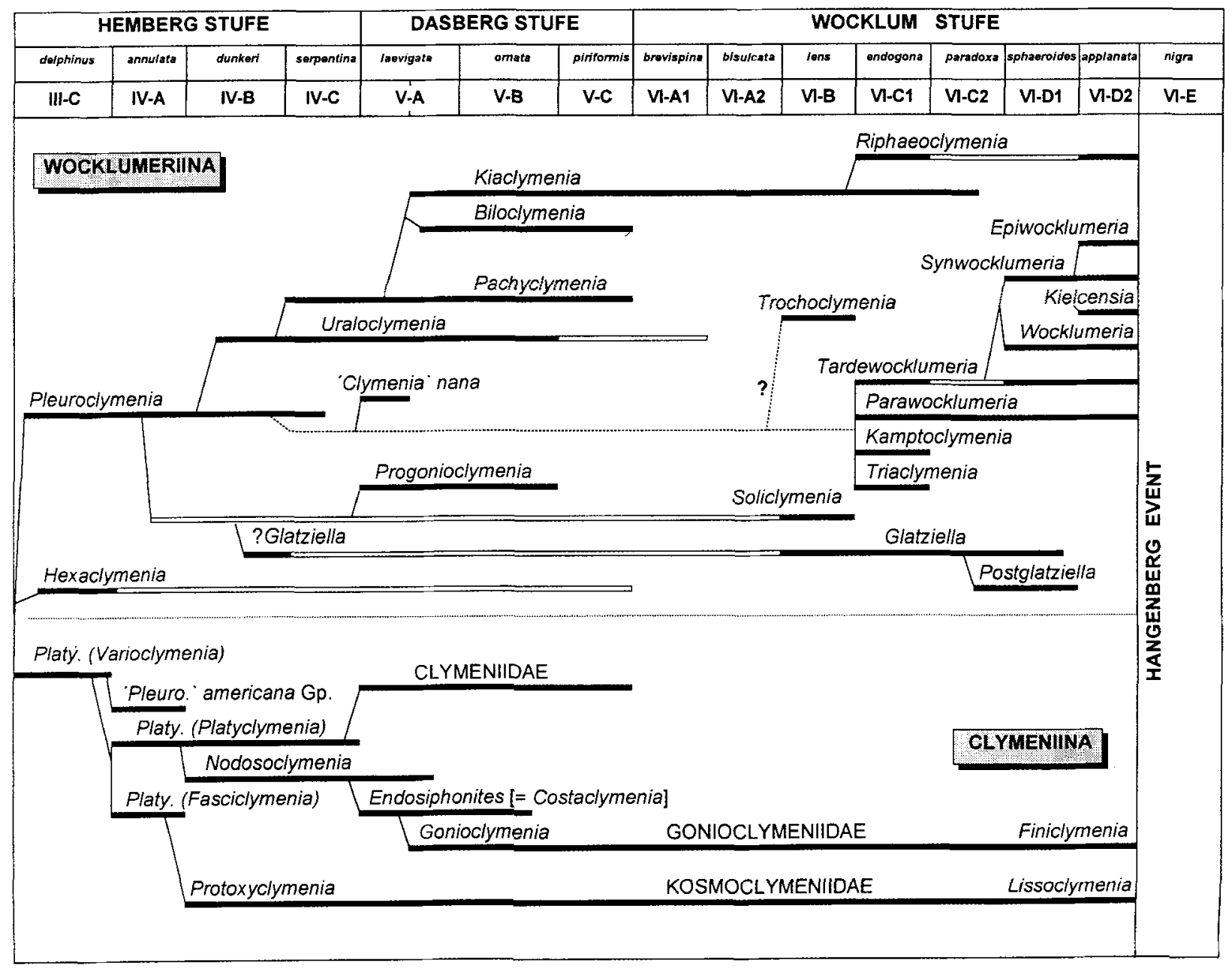

Fig. 12. Stratigraphical ranges and supposed phylogenetical relationships within middle to late Famennian genera of the Wocklumeriina and of selected Clymeniina groups (Clymeniaceae: Platyclymeniidae, Clymeniidae, Kosmoclymeniidae; Gonioclymeniaceae: Costaclymeniidae, Gonioclymeniidae) 
whorls, short body chambers, narrow, deep dorsal lobes and trends towards large size are also common in both groups. Nodosoclymenia preceded the oldest Gonioclymeniaceae (Costaclymenia Schindewolf, a junior synonym of Endosiphonites Ansted) immediately in the late Hemberg Stufe and, as noted by Dzik (1991) and Becker \& Kullmann (1996), has to be seen as the phylogenetic link between Platyclymeniidae (Clymeniaceae) and Gonioclymeniaceae (Fig. 12). There are no intermediate forms between Hexaclymeniidae and Costaclymeniidae to support Schindewolf's (1937, 1949) phylogenetic views. Nodosoclymenia occurs not only in Poland, but also in the Rhenish Massif (e.g., fragments from UD IV-B of the Nie Brickwork Quarry). Earliest Costaclymeniidae such as Endosiph. muensteri Ansted (= limatus Czarnocki) have very shallow ventral lobes. Ventral "pseudolobes" developed in several other Clymeniaceae (Platyclymeniidae: Stenoclymenia, Cyrtoclymeniidae: Pricella. Cymaclymeniidae: Kazakhoclymenia) independently. Narrow "true" ventral lobes are characteristic of the Sellaclymeniidae and Gonioclymeniidae which both were derived from the Costaclymeniidae (see Schindewolf 1949 and Weyer 1981).

The traditional Gonioclymeniina are clearly polyphyletic and have to be broken down into the monophyletic Gonioclymeniaceae (= Sellaclymeniaceae) as descendents of the Clymeniaceae on one side, and into the Wocklumeriaceae and Glatziellacea on the other side. Both groups evolved in parallel since the earliest time of clymenid evolution and represent two natural larger groups which should be recognized at suborder level. The Clymeniina Wedekind, 1914 (= Platyclymeniina Schindewolf, 1923b) combine the brevidomic/mesodomic Cyrtoclymeniaceae (convolute), Clymeniaceae (evolute) and Gonioclymeniaceae (evolute, always with lateral and ventral lobes). The Wocklumeriina embrace all primarily longidomic lineages with originally wide and shallow and subsequently often divided dorsal and ventral lobe.

\section{Biloclymeniaceae Bogoslovskiy 1955 (nom. transl. by Becker, 1997b)}

Bogoslovskiy $(1977,1981)$ investigated the phylogeny of the Miroclymeniidae Schindewolf (1924) which then included the UraloclymeniaPachyclymenia lineage as well as the enigmatic Miroclymenia. Korn (1981) placed the latter in synonymy with Cymaclymenia. The Miroclymeniidae consequently became a younger synonym of the Cymaclymeniidae Hyatt. The main con- tent of the former Miroclymeniidae was later placed by Korn (1992b) in his new family Pachyclymeniidae. The latter and the descendent Biloclymeniidae are united here in the superfamily Biloclymeniaceae. They are characterized by mostly relative involute, compressed, moderately fast expanding whorls, biconvex growth lines, wide ventral lobes which may become divided (Figs $11 \mathrm{c}-\mathrm{f}$ ), and by body chambers of about one whorl in length. The group represents a very characteristic evolutionary branch which cannot be confused with other clymenids although the shell-form of some taxa may resemble cymaclymenids with thick whorls. Bogoslovskiy (1977, 1981) followed Schindewolf's (1937) idea of phylogenetic links with the Hexaclymeniidae. This is not only supported by ventral lobes of early members as in some Hexaclymeniidae (compare Uraloclymenia and Pleuroclymenia, Glatziella and Kiaclymenia; see Bogoslovskiy 1981 and Figs 10. 11) but also by the long septal necks found in Pachyclymenia, Kiaclymenia and Biloclymenia (Schindewolf 1937, Bogoslovskiy 1976).

The Biloclymeniaceae were most likely derived from unribbed pleuroclymenids and are placed in the Wocklumeriina. All Pleuroclymenia and several Pachyclymeniidae (e.g., Borkowia kozlowskii Czarnocki; here placed in Uraloclymenia, most Pachyclymenia) have characteristic internal shell thickenings (mould constrictions). The mostly convolute and compressed whorl cross-section gives a clear distinction of Biloclymeniaceae from Hexaclymeniidae but primitive species such as Uralo. kazakhstanica Bogoslovskiy and Uralo. lateumbilicata Bogoslovskiy are morphologically intermediate to smooth forms such as Pleuro. kasachstanica (Pl. 1: 8, 9). The stratigraphical age and Asian distribution of smooth pleuroclymenids (UD III-C) and early Pachyclymeniidae is in good accordance with close affinities. Differences in growth line ornament may be the result of the change to a more pelagic lifestyle. The Biloclymeniaceae differ from the Glatziellaceae in their somewhat shorter body chamber and more compressed, faster expanding whorl-profile (sometimes only of late stages). The keeled Riphaeoclymenia (Bogoslovskiy $1981=$ Dimeroclymenia and Liroclymenia of Czarnocki 1989) however, is a larger-sized homoemorph of evolute glatziellids which indicates a morphological reversal in a late phylogenetical branch of the group. The Biloclymeniaceae are distinguished from the Wocklumeriaceae by the lack of triangular ontogenetic stages and by the undivided dorsal lobe. 


\section{Taxonomy}

\section{Suborder Wocklumeriina Becker 1997b}

Diagnosis (emended from Becker 1997b): Extremely evolute to completely involute, smooth or ribbed, whorl section mostly depressed; body chamber originally longidomic, mesodomic in some derived groups; suture primarily with shallow and wide dorsal lobe, adventitious flank lobe and wide ventral lobe, advanced forms with narrow, subdivided or reduced dorsal and ventral lobes; lateral and umbilical lobes re-appear around the umbilicus in some groups; septal necks long to extremely long (holochoanitic).

Included superfamilies: Glatziellaceae Schindewolf, 1928, Biloclymeniaceae Bogoslovskiy, 1955, and Wocklumeriaceae Schindewolf, 1937. In advanced members of Glatziellaceae only the ventral lobe became more complex, in advanced Biloclymeniaceae the ventral lobe was divided and umbilical lobes were added, and in the Wocklumeriaceae there were changes both in the ventral and dorsal lobe.

Remarks: The Clymeniina differ in their brevidomic to mesodomic conchs which increase faster in whorl height and which are mostly compressed. There are no primary wide and shallow ventral lobes. The dorsal lobe is deep and narrow. Derived and broad-whorled Clymeniina may have a wider dorsal lobe but usually there is a small median (siphuncular) truncation left (see 'Pleuro.' eurylobica Petersen 1975: pl. 7 , fig. 5). Data on septal necks in Clymeniina are still rather insufficient but some taxa have very short, others long necks (Bogoslovskiy 1976, Drushchits et al. 1976).

Stratigraphical range: Middle Hemberg (Prolobites delphinus Zone, UD III-C) to upper Wocklum Stufe (Epiwo. applanata Subzone, UD VI-D ${ }_{2}$.

\section{Glatziellaceae Schindewolf, 1928 (nom. transl.)}

Diagnosis: Extremely evolute to involute, smooth or ribbed, body chamber longidomic (longer than one whorl), whorls slowly expanding and with low apertures. Sutures with simple and wide dorsal lobe, adventitious flank lobe and wide ventral lobe which may be subdivided by median saddles and secondary ventral lobes. Sutural formulas: EA:I - $\left(E_{1}-E_{1}\right) A: I-E_{2} E_{1} A I$ $-\left(E_{2}-E_{2}\right) E_{1} A I$.
Included families: Hexaclymeniidae Lange, 1929 and Glatziellidae, Schindewolf 1928. Weyer (1981) preferred to recognize both groups only at subfamily level. Trochoclymenia possibly belongs here as well. If this can be proven, it should form the base for a third family with umbilical lobes.

Stratigraphical range: Middle Hemberg (Prolobites delphinus Zone, UD III-C) to upper Wocklum-Stufe (Wo. sphaeroides Subzone, UD VI-D ${ }_{1}$ ).

Geographical distribution: Germany (Rhenish Massif, Thuringia, Franconia, Harz Mountains), Carnic Alps (Austria/northern Italy), Great Britain (Devon, Cornwall), Poland (Holy Cross Mts., Silesia, Carpathian Foreland, Lublin Basin), Morocco, Russia (Urals), Kazakhstan (Mugodzhar Mts.), South China (Guizhou).

\section{Family Hexaclymeniidae Lange, 1929}

Diagnosis (emended from Lange, 1929): Small to medium-sized, evolute to extremely evolute, smooth or ribbed, often with internal shell thickenings (mould constrictions), venter rounded, flat, bicarinate or slightly keeled; dorsal and ventral lobes simple, wide and rounded. Sutural formula: EL:I.

Included genera: Pleuroclymenia Schindewolf, 1934, Gyroclymenia Czarnocki, 1989 (= Pleuroclymenia), Hexaclymenia Lange, 1929, Progonioclymenia Schindewolf, 1937, Soliclymenia Schindewolf, 1937, Gen. nov. (Clymenia nana Group).

Stratigraphical range: Middle Hemberg (Prolobites delphinus Zone, UD III-C) to lower Wocklum Stufe (Balvia (Kenseyoceras) lens Zone, UD VI-B).

Geographical distribution: Rhenish Massif, Harz Mts., Franconia, Maïder, ?Devon (?Pleuroclymenia in House 1959), Carnic Alps, Holy Cross Mts., Silesia, Urals, Mugodzhar Mts. Records from North America, Asia and Australia are lacking so far. Thus, the family may have been restricted to the western part of the Prototethys and to the Ural ocean.

\section{Pleuroclymenia costata (Lange, 1929)}

Fig. 10d, Pl. 1: 11-14 $\begin{aligned} *+ & \text { Platyclymenia crassa Schindewolf: } 162 \\ & \text { [nom. nud., non quenstedti var. crassa }\end{aligned}$ nom. nud.] 


\begin{tabular}{|c|c|c|}
\hline & 1922 & $\begin{array}{l}\text { Platyclymenia (Varioclymenia) brevicostata } \\
\text { Kegel: } 39 \text { [fide Schindewolf 1924] }\end{array}$ \\
\hline+ & $1923 b$ & $\begin{array}{l}\text { Platyclymenia crassa Schindewolf: } \\
458-459 \text {. fig. } 19 \mathrm{c} \text { [non Plat: quenstedti } \\
\text { var. crassa = ?Pleturo. crassa] }\end{array}$ \\
\hline$\because$ & 1924 & Platyclymenia crassa Schindewolf: 100 \\
\hline$*$ & 1929 & $\begin{array}{l}\text { ?Cicloclymenia costata Lange: } 24.63 . \\
\text { pl. } 2 \text {. fig. } 14\end{array}$ \\
\hline$\because$ e.p. & 1929 & $\begin{array}{l}\text { Platyclymenta (Varioclymenia) brevicosta } \\
\text { Lange: } 20 \text { [only ammulata Zone record] }\end{array}$ \\
\hline & 1931 & $\begin{array}{l}\text { Platyclymenia crassa crassa Matern: } 102 \\
\text { [non quenstedti crassoides = crassa] }\end{array}$ \\
\hline v & 1934 & $\begin{array}{l}\text { Platyclymenia (Pleturoclymenia) crassa } \\
\text { Schindewolf: } 343\end{array}$ \\
\hline$\therefore ?$ & 1936 & $\begin{array}{l}\text { Platyclymenia (Pleuroctymenia) aff. crassa } \\
\text { Paeckelmann: } 31\end{array}$ \\
\hline$\because ?$ & 1938 & $\begin{array}{l}\text { Platyclymenia (Pleuroclymenia) crassa } \\
\text { Paeckclmann: } 25\end{array}$ \\
\hline+ & 1955 & $\begin{array}{l}\text { Platychmenia (Pleuroclymenia) crassissi- } \\
\text { ma Schindewolf: } 428 \text { [nom. nov.] }\end{array}$ \\
\hline+ & 1956 & $\begin{array}{l}\text { Platyclymenia (Pleurochmenia) crassima } \\
\text { Müller: } 69 \text { [nom. vad.] }\end{array}$ \\
\hline$\because+$ & 1989 & $\begin{array}{l}\text { Gyroctymenia rotundata Czarnocki: } 32 . \\
\text { pi. I. figs } 17 . \text { 17a. pl. II. figs } 8 . \\
\text { pl. XXXIX. fig. } 3 \text { b. pl. XL. fig, } 2 \text { a. b }\end{array}$ \\
\hline
\end{tabular}

Types: The illustrated specimen of Lange (1929) from the annulata Zone (UD IV-A) of the Beul, here designated as lectotype, has been misplaced and may be lost. It is possible that syntypes are preserved in the collection at Hamburg University. The holotype of Pleuro. crassissima from the annulata Zone of Kirschhofen is No. 3154 in the Schindewolf collection at Marburg. Figures of it have been made available by J. Price/M.R. House and D. Korn.

Description: In the holotype of Pleuro. crassissima, inner whorls have marked straight. somewhat rursiradiate ribs which become finer on the last whorl and which are, from ca. $30 \mathrm{~mm} \mathrm{dm}$ on. restricted to the inner flanks. There are several mould constrictions and the venter is broadly rounded. The Berlin topotype of the same species (MB.C.1266, Pl. 1: 10-12) is preserved in dark grey to brownish limestone. The last whorl has been eroded on one side and shows five concave constrictions which are restricted to the venter. There are slightly more than thirty rounded, straight, rursiradiate ribs on the last whorl which terminate at the flank shoulders and on the lower part of the deep and rounded umbilical wall. The maximum whorl width lies in the ribbed middle part of the flanks. Early whorls have a more depressed cross-section than later ones. Sutures show a high saddle at the umbilical seam from where they deflect backwards in gentle curvature (Fig. 10d). A very wide and flattened E-lobe is not really separated from the widely curved adventitious flank lobe. Similar sutures were illustrated by Czarnocki (1989) for his Gyro. angulata and juvenile Gyro. cyclocostata.
Five specimens from the Hauern give insights into the variability of the species and show fine, lirate, densely spaced ( $>10$ per $\mathrm{mm}$ ) convex growth lines. Ribs are sometimes slightly concave on the flanks. For dimensions see Table 2. In MB.C.1806.4, the wrinkle layer, consisting of rectiradiate, rarely branching wrinkles, covers the hair keel of the preceeding whorl. MB.C.1806.2 has a healed shell fracture as it can be expected from longidomic bottom-dwellers.

Remarks: There is certainly taxonomic oversplitting in Pleuroclymenia. Large collections are needed to decide which taxa should be kept and which should be put into synonymy or should only be recognized at subspecies level. Schindewolf's holotype and Lange's lectotype are slightly more involute than the Berlin topotype of Pleuro. crassissima. Pleuro. varicata (Sobolev) is even more involute (uw $<40 \% \mathrm{dm}$ ) and more compressed. The latter is also true for Pleuro. angulata (Czarnocki), Pleuro. cyclocostata (Czarnocki), and the very evolute Pleuro. evoluta (Czarnocki). Pleuro. rotundata (Czarnocki) has similar shell parameters as costata and is regarded as a junior subjective synonym. Pleuro. kasachstanica, Pleuro. mutabilis (Czarnocki) and Pleuro. sophiae (Czarnocki) loose the ribbing during different ontogenetic phases.

Stratigraphical range: Annulata Zone (UD IV-A) of the Rhenish Massif to Protoxyclymenia Zone (UD IV-B) of the Holy Cross Mountains (Besówka) and of the Kia section (Bogoslovskiy in Simakov et al. 1983).

\section{Pleuroclymenia kasachstanica Kind, 1944}

Pl. 1: 8.9

$\begin{array}{ccl}* \quad 1944 & \begin{array}{l}\text { Platyclymenia (Varioclymenia) kasachstani- } \\ \text { ca Kind: } 160-161,166, \text { pl. } 1, \text { figs } 16-17\end{array} \\ \therefore ? & 1944 & \begin{array}{l}\text { Platyclymenia (Varioclymenia) kasachstani- } \\ \text { ca var. simplex Kind: } 161,166\end{array}\end{array}$

Material: A purchased single topotype (?syntype. MB.C.1731, Pl. 1: 8, 9).

Description: The specimen is well-preserved and complete. The preserved part of the body chamber is longer than one whorl. Coarse recrystallisation prevents a clear recognition of complete sutures but undoubtedly there is a relative high saddle at the umbilical seam followed by a gently curved flank lobe that grades into a straight or only slightly undulose part across the outer flanks and venter. Dense straight, slightly rursiradiate flank ribbing (ca. 25-30 ribs per 
whorl) is present until $6 \mathrm{~mm} \mathrm{dm}$. Last undulose ribs disappear at ca. $8 \mathrm{~mm} \mathrm{dm}$. Smooth adult whorls have few and shallow constrictions which are restricted to the flatly rounded venter. The whorl cross-section is subrectangular with maximum flank width on the mid-flank. For dimensions see Table 2.

Remarks: Pleuro. mutabilis is a related species with rather variable conch parameters (uw and wd) that still has subdued dense ribs at median stages. Uralo. lateumbilicata Bogoslovskiy (1977) is more involute, thicker, and has well-developed A- and E-lobes.

Stratigraphical range: Delphinus Zone (UD III-C) of Kasakhstan. Bogoslovskiy (in Simakov et al. 1983) quotes the species also from strata with Protoxyclymenia (UD IV-B) at Kia.

\section{Pleuroclymenia cyclocostata (Czarnocki, 1989)}

Pl. 2: 3, 4

$\begin{array}{lll}* & 1972 \quad \begin{array}{l}\text { Gyroclymenia cyclostata Pajchlowa: } 100 \\ \text { [nom. nud.] }\end{array} \\ + & 1989 \quad \begin{array}{l}\text { Gyroclymenia cyclocostata Czarnocki: 13, } \\ 23,33, \text { pl. I, figs 1-5, 9, 12-13, 16, } \\ \text { pl.XXXIX, figs 1b, 2a, 2b, pl. XL, fig. 5 }\end{array} \\ \text { *v } 1992 \quad \begin{array}{l}\text { Gyroclymenia cyclocostata Becker: 12 }\end{array}\end{array}$

Description: MB.C.1732 (Pl. 2: 3, 4) is an internal mould which has been eroded on one side. Only about the last two whorls are preserved. The cross-section is subrectangular with flattened, rounded venter and weakly rounded flanks. The body chamber occupies more than the last whorl (ca. $380^{\circ}$ ). The latter displays 32 distinctive straight ribs which terminate at the ventrolateral shoulders. The venter has four marked constrictions with rather deep median sinus. Ribs and constrictions do not overlap. The last septum shows a high saddle at the umbilical seam and a wide and rounded A-lobe on the ribbed flank. Ventral parts are not visible. For dimensions see Table 2.

Remarks: In terms of umbilical widths (ca. $53 \% \mathrm{dm})$ and $\mathrm{wh} / \mathrm{ww}$ ratio $(0.69$ to 0.74$)$, the Sauerland specimen is somewhat intermediate between Pleuro. cyclocostata and Pleuro. evoluta. Pleuro. angulata (uw $=42-44 \% \mathrm{dm}$ ) and Pleuro. varicata (uw $<40 \% \mathrm{dm}$ ) are also compressed but much more involute.

Stratigraphical range: Delphinus Zone (UD III-C) of the Rhenish Massif and Holy Cross Mountains (Ostrówka, ?Kielce).

\section{Pleuroclymenia mutabilis (Czarnocki, 1989)}

Pl. 2: 1, 2

*+ 1989 Gyroclymenia mutabilis Czarnocki: 23, 33. pl. II, figs 2, 4, 6, 10, pl. XXXIX. fig. 3d. pl. XL, fig. $4 a, b$

Description: Three specimens from the Hauern near Braunau (Kellerwald) conform to the species as illustrated by Czarnocki (1989). The cross-section is broad kidney-shaped with wellrounded venter. Ventral constrictions are seen in MB.C.1807.2 (Pl. 2: 1, 2). The ribbing weakens between 10 and $15 \mathrm{~mm}$ dm and is rather dense (25 to 35 ribs per whorl). A suture is poorly visible on MB.C.1807.1 and has a high saddle at the umbilical seam and a rounded flank lobe extending straight to the venter, similar as shown by Czarnocki in Pleuro. angulata. Growth lines are very fine (up to $13 / \mathrm{mm}$ ), lirate and straight to convex on the flanks. A wide ventral sinus is developed. MB.C.1762, det. Platy. (Pleuro.) crassa, from Burg (Rösenbeck Syncline, sheet 4518 Madfeld) resembles the Kellerwald specimens but is rather poorly preserved.

Stratigraphical range: Annulata Zone (UD IV-A) of the Rhenish Massif and UD IV-B of the Holy Cross Mountains (Besówka, Kielce).

\section{Superfamily Wocklumeriaceae Schindewolf, 1937 (emend.)}

Diagnosis: Evolute to completely involute (umbilicus closed), smooth, early ontogenetic stages triangularly coiled with regular constrictions, adult stages triangular or normally coiled, body chamber very longidomic (much more than one whorl), sutures with divided or completely reduced dorsal and ventral lobes. Sutural formulas: $\left(E_{1}-E_{1}\right) A:\left(I_{1}-I_{1}\right)-A-A L_{e}: L_{i}\left(I_{1}-I_{1}\right)-$ $\mathrm{EAL}_{\mathrm{e}}: \mathrm{L}_{\mathrm{i}} \mathrm{I}_{1} \mathrm{I}_{2}$.

Included families: Parawocklumeriidae Schindewolf, 1937 and Wocklumeriidae Schindewolf, 1937.

Stratigraphic range: Upper Wocklum-Stufe (endogona Subzone, UD VI- $\mathrm{C}_{1}$, to applanata Subzone, VI- $\mathrm{D}_{2}$ ).

Geographical distribution: See Table 1.

\section{Family Parawocklumeriidae Schindewolf, 1937}

\section{Kamptoclymenia endogona Schindewolf, 1937}

Figs 5a-b, 6a, 7, Pl. 3: 3, 4

1902 Phenacoceras ? paradoxum Frech: 63. pl. 3, fig. 5 [fide Schindewolf 1937] 


\begin{tabular}{|c|c|c|}
\hline \multirow[t]{2}{*}{$*+v$} & 1937 & $\begin{array}{l}\text { Kamptoclymenia endogona Schindewolf: } \\
88-89 \text {. text-figs } 20.24 \text {. pl. } 3 \text {. figs } 8-15\end{array}$ \\
\hline & 1950 & $\begin{array}{l}\text { Kamptoclymenia endogona Schindewolf: } \\
\text { 262. text-fig. } 226 \mathrm{~h}\end{array}$ \\
\hline * & 1959 & $\begin{array}{l}\text { Kamptoclymenia endogona Lewowicki: } 78 \text {. } \\
81.100 .109 \text {. pl. I. fig. } 5\end{array}$ \\
\hline ff. & 1989 & $\begin{array}{l}\text { Kamptoclymenia aff. endogona Czarnocki: } \\
41-42 \text {. pi. III. fig. } 7\end{array}$ \\
\hline & 1993 & Kamptoclymenia endogona Korn: fig. 3 \\
\hline
\end{tabular}

Type: Schindewolf's holotype from Bed 8 at Oberrödinghausen is lost, and MB.C.1813.1 from Bed 7, the only more or less complete larger paratype, is designated as neotype. The specimen is probably the original of Schindewolf's textfig. $20 \mathrm{~b}$.

Description: The neotype has at ca. $10 \mathrm{~mm}$ $\mathrm{dm}$ a distinctive concave constriction on the gently curved venter. Sutures show that the saddle between E- and A-lobes is mostly not as well-developed as in Schindewolf's illustration. The median saddle is very low giving only a slight difference to Pleuroclymenia sutures (Fig. 6a). Early whorls are not well-preserved in the neotype but triangular coiling is visible in juvenile paratypes such as MB.C.1813.2-3. Shell measurements of syntypes (Table 3) show that extreme conch evolution (uw $>60 \% \mathrm{dm}$ ) develops rather late in ontogeny $(\mathrm{dm}>10 \mathrm{~mm})$. Shell compression increases during growths and wh/ ww ratios rise from around 0.5 to 0.8 .

Remarks: Kampto. endogonoides differs only by more depressed whorl profile at median ontogenetic stages. Kampto. trigona has extended triangular stages and also thicker whorls.

Stratigraphical range: Lower to upper part of endogona Subzone (UD VI- $\mathrm{C}_{1}$ ).

\section{Kamptoclymenia trigona Schindewolf, 1937}

Fig. 7, Pl. 3: 5, 6

\begin{tabular}{|c|c|c|}
\hline & 1937 & $\begin{array}{l}\text { Kamptoclvmenia trigona } \\
89-90 \text {. pl. 3. figs } 16-18\end{array}$ \\
\hline & 1950 & $\begin{array}{l}\text { Kamptoclymenia trigona Schindewolf: } 262 \text {. } \\
\text { text-fig. } 226 \mathrm{i}\end{array}$ \\
\hline 9 & 1989 & $\begin{array}{l}\text { Triaclymenia of. triangularis Czanocki: } \\
\text { pl. XI. fig. } 14 \text { [only] }\end{array}$ \\
\hline & 1993 & Kamptoclymenia trigona Korn: fig. 3 \\
\hline
\end{tabular}

Type: Schindewolf's holotype from Bed 8 at Oberrödinghausen has been lost. A second specimen from Bed 8. MB.C.1751, the largest complete paratype, is here designated as neotype.

Remarks: Schindewolf has given a good description of his species. Widely spaced shallow to distinctive constrictions with marked sinus are, as in Pleuroclymenia, restricted to the venter
(MB.C.750.1-2). They are slightly eroded on the neotype. None of the available specimens shows sutures. Shell parameters of some specimens are given in Table 3. As in Kampto. endogona, adult whorls become more evolute (uw reaches up to $2 / 3$ of $\mathrm{dm}$ ) and their wh/ww ratios finally exceed 0.5 .

Stratigraphic range: Lower (Korn 1993) to upper (Schindewolf 1937) part of endogona Subzone (UD VI-C $)_{1}$ ).

\section{Triaclymenia triangularis Schindewolf, 1937}

Figs 5c, 7, Pl. 3: 7, 8, 15

\begin{tabular}{|c|c|c|}
\hline$+v$ & 1937 & $\begin{array}{l}\text { Triaclymenia triangularis Schindewolf: } 91 \text {, } \\
\text { text.-fig. } 22 \text {. pl. } 3 \text {, figs } 3, ? 4\end{array}$ \\
\hline & 1950 & $\begin{array}{l}\text { Triaclymenia triangularis Schindewolf: } 262 \text {, } \\
\text { text-fig. } 2261\end{array}$ \\
\hline ion & 1989 & $\begin{array}{l}\text { Triaclymenia cf. triangularis Czarnocki: } 42 \text {, } \\
\text { pl. XI, figs } 1,6,14 \text { [fig. } 14=\text { ? Kampto. tri- } \\
\text { gona, figs } 1 \text { and } 6 ?=\text { convolute species } \\
\text { such as Tria. primaeva, Parawo. distorta or } \\
\text { Tardewo. distributa] }\end{array}$ \\
\hline
\end{tabular}

Types: Schindewolf's holotype from Bed 10 at Oberrödinghausen has been lost. A second, relatively large but rather poorly preserved paratype from Bed 10 (MB.C.1815, Pl. 3: 7, 8) is designated as neotype. It is the only specimen that shows sutures and is the original of Schindewolf's text-figure 22 .

Remarks: The compressed, evolute (uw = $40-50 \% \mathrm{dm}$ ) shell form, with adult wh/ww ratios of 0.8 or more, allows easy distinction from Kampto. varicata and Parawo. patens, even if sutures are not preserved. MB.C.1817 is an adult whorl fragment showing subtriangular cross-section (Pl. 3: 15) and the formation of an incipient keel. Its growth lines have a very shallow flank sinus. a very low and short ventrolateral salient and a small, diverging ventral sinus.

Stratigraphical range: Lower to Upper part of endogona Subzone (UD VI- $C_{1}$ ).

\section{Parawocklumeria paradoxa (Wedekind, 1918)}

Figs 5d-f, 7, Pl. 4: 5, 6

\begin{tabular}{|c|c|c|}
\hline$+*$ & 1916 & $\begin{array}{l}\text { Wocklumeria paradoxa Schindewolf: } 36 \\
\text { [nom. nud.] }\end{array}$ \\
\hline$+v$ e.p. & 1918 & $\begin{array}{l}\text { Wocklumeria paradoxa Wedekind: } 172- \\
\text { 173, pl. XIX, fig. } 16 \text { [non fig. } 17=\text { Parawo. } \\
\text { paprothae] }\end{array}$ \\
\hline$*$ & 1921 & Wocklumeria distorta Schmidt: 290 \\
\hline$*$ v e.p. & 1924 & $\begin{array}{l}\text { Wocklumeria distorta Schmidt: } 121 \text {, pl. } 6 \text {, } \\
\text { figs } 14-15 \text { [e.p. = Wo. sphaeroides juv.] }\end{array}$ \\
\hline$\therefore$ & 1924 & Wocklumeria distorta Paeckelmann: 85 \\
\hline & 1926 & $\begin{array}{l}\text { Parawocklumeria paradoxa Schindewolf: } \\
\text { 114. lootnote } 7\end{array}$ \\
\hline$*$ & 1929 & Wocklumeria paradoxa Lange: $3(0,31$ \\
\hline
\end{tabular}




\begin{tabular}{|c|c|c|}
\hline$*_{v}$ e.p. & 1937 & $\begin{array}{l}\text { Parawocklumeria paradoxa Schindewolf: } \\
15,16,17,21,22,27,3043,4495-96 \text {, text- } \\
\text { fig. } 23 \text {, pl. } 4 \text {, figs } 11-16 \text { [e.p. = paprothae] }\end{array}$ \\
\hline & 1950 & $\begin{array}{l}\text { Parawocklumeria paradoxa Schindewolf: } \\
260,262 \text {, text-fig. } 225,226 \mathrm{n}\end{array}$ \\
\hline : & 1954 & Parawocklumeria paradoxa Pfeiffer: 58 \\
\hline$+*$ & 1960 & $\begin{array}{l}\text { Parawocklumeria laevigata Selwood: } 156 \text {, } \\
167-168, \quad 169, \quad \text { text-fig. } 4 \mathrm{~A}, \quad \text { pl. } 27, \\
\text { figs } 16-20\end{array}$ \\
\hline$+^{*}$ & 1960 & $\begin{array}{l}\text { Parawocklumeria laevigata var. obesa Sel- } \\
\text { wood: } 156,169, \text { text-fig. } 4 \mathrm{~B}, \quad \text { pl. } 28 \text {, } \\
\text { figs } 1-2\end{array}$ \\
\hline & 1960 & $\begin{array}{l}\text { Parawocklumeria paradoxa Müller: } 145 \text {, } \\
\text { text-fig. 1991-m }\end{array}$ \\
\hline * & 1964 & Parawocklumeria paradoxa Sun: pl. 1, fig. 3 \\
\hline * & 1965 & $\begin{array}{l}\text { Parawocklumeria paradoxa Sun \& Shen: } \\
36, \quad 37, \quad 39,66-67 \text {, text-fig. } 23 \text {, pl. I, } \\
\text { figs } 11-12\end{array}$ \\
\hline & 1979 & Parawocklumeria paradoxa Weyer: 99 \\
\hline * & 1979 & $\begin{array}{l}\text { Parawocklumeria paradoxa Clausen et al.: } \\
59\end{array}$ \\
\hline * & 1980 & $\begin{array}{l}\text { Parawocklumeria paradoxa Bartzsch \& } \\
\text { Weyer: } 39\end{array}$ \\
\hline * & 1981 & Parawocklumeria paradoxa Korn: tab. 1 \\
\hline *e.p. & 1981 & $\begin{array}{l}\text { Parawocklumeria laevigata Bogoslovskiy: } \\
107-109 \text {, pl. XVI, figs } 6-10 \text { [e.p. probably } \\
=\text { paprothae }\end{array}$ \\
\hline * & 1981 & $\begin{array}{l}\text { Parawocklumeria paradoxa Ruan: } 114- \\
115 \text {, text-fig. } 81 \text {, pl. } 28 \text {, figs } 17-25,37-38\end{array}$ \\
\hline & 1982 & $\begin{array}{l}\text { Parawocklumeria paradoxa Bartzsch \& } \\
\text { Weyer: text-fig. } 14.2\end{array}$ \\
\hline & 1983 & $\begin{array}{l}\text { Parawocklumeria laevigata Simakov et al.: } \\
\text { tab. } 2\end{array}$ \\
\hline $\mathrm{*} \mathrm{V}$ & 1984 & $\begin{array}{l}\text { Parawocklumeria paradoxa Becker et al.: } \\
189\end{array}$ \\
\hline * & 1985 & $\begin{array}{l}\text { Parawocklumeria paradoxa Sheng: } 89- \\
90, \text { pl. 11, figs 5-8 }\end{array}$ \\
\hline & 1985 & Parawocklumeria paradoxa Gong et al.: 26 \\
\hline$* \mathrm{v}$ & 1986 & $\begin{array}{l}\text { Parawocklumeria paradoxa Paproth et al.: } \\
4,21\end{array}$ \\
\hline
\end{tabular}

1987

$\begin{array}{ll}*_{\mathrm{v}} & 1988 \\ \text { *e.p. } & 1989\end{array}$

e.p. 1989

1989a Parawocklumeria paradoxa Clausen et al.: text-fig. 3, pl. 4, figs 14-18

1989b Parawocklumeria paradoxa Clausen et al.: 176,221

1989 Parawocklumeria paradoxa Sheng in Ji et al.: $118-119, \mathrm{pl} .32$, figs $1 \mathrm{a}-4 \mathrm{~b}$

1992a Parawocklumeria paradoxa Korn: 9, text-

$\begin{array}{ll} & \text { fig. 3, Pl. 1, figs 1-2 } \\ \text { v e.p. } 1993 & \text { Parawpcklumeria paradoxa Becker et al.: }\end{array}$ $23,25,38,50,51,52,56$ [old Schindewolf records e.p. $=$ paprothae $]$

1993 Parawocklumeria paradoxa Korn: figs 3, 8

1994 Parawocklumeria paradoxa Luppold et al.: 21,34

1994 Parawocklumeria paradoxa Korn et al.: 116

1995a Parawocklumeria paradoxa Korn: 162, text-figs 3,5

1995b Parawocklumeria paradoxa Korn: figs 12.2, 12.4

1996 Parawocklumeria paradoxa Becker: 22, 23. 24, pl. 2, fig. 8

1998 Parawocklumeria paradoxa Bartzsch et al.:

1999 Parawocklumeria paradoxa Korn: 153. text-fig. 3, pl. 3, fig. 2

Type: In the Göttingen collection five syntypes are preserved, including the original of Wedekind's pl. XIX, fig. 17 (GPIG 389-78a) which shows a typical suture on a polished part of an earlier whorl. Preparation of the umbilical region,

Table 3

Dimensions of various Parawocklumeriidae.

\begin{tabular}{|c|c|c|c|c|c|c|c|}
\hline species/specimen & $\mathrm{dm}$ & uw & wh & ww & uw\% & $w w \%$ & wh/ww \\
\hline \multicolumn{8}{|l|}{ Kampto. endogona } \\
\hline lost holotype & 25.8 & 15.7 & 5.5 & 7 & 60.9 & 27.1 & 0.79 \\
\hline neotype MB.C.1813.1 & 12.3 & 7.7 & 2.8 & 4.7 & 62.6 & 38.2 & 0.6 \\
\hline MB.C. 1813.2 & 7 & 3.9 & 1.75 & 3.1 & 55.7 & 44.3 & 0.56 \\
\hline MB.C. 1813.3 & 6.3 & 3.7 & 1.4 & 2.8 & 58.7 & 44.4 & 0.5 \\
\hline MB.C. 1812.2 & 4 & 2.1 & 1 & 2.2 & 52.5 & 55 & 0.45 \\
\hline \multicolumn{8}{|l|}{ Kampto. endogonoides } \\
\hline holotype 33544 & 10.5 & 5.8 & 2.3 & 5.1 & 55.2 & 48.6 & 0.45 \\
\hline \multicolumn{8}{|l|}{ Kampto. trigona } \\
\hline lost holotype & 15 & 9.3 & 3 & 6.3 & 62 & 42 & 0.48 \\
\hline neotype MB.C. 1751 & 12.2 & 8 & 2.5 & 4.7 & 65.6 & 38.5 & 0.53 \\
\hline neotype MB.C.1751 & 9 & 6 & 1.75 & 3.8 & 66.7 & 42.2 & 0.46 \\
\hline MB.C. 1750.2 & 9 & 5 & 2.2 & 4.5 & 55.6 & 50 & 0.49 \\
\hline MB.C. 1750.3 & 5.9 & 3.3 & 1.3 & 3.2 & 55.9 & 54.2 & 0.41 \\
\hline MB.C. 1750.3 & 3.6 & 1.9 & 0.9 & 2.2 & 52.8 & 61.1 & 0.41 \\
\hline \multicolumn{8}{|l|}{ Tria. triangularis } \\
\hline neotype MB.C. 1815 & 18 & 9 & 5 & 6 & 50 & 33.3 & 0.83 \\
\hline lost holotype & 16 & 6.5 & ca. 6 & ca. 7.5 & 40.6 & 46.9 & ca. 0.8 \\
\hline MB.C. 1816 & 9.3 & 4.3 & 3.1 & 4.2 & 46.2 & 45.2 & 0.74 \\
\hline \multicolumn{8}{|l|}{ Tria. primaeva } \\
\hline holotype 502 & 19 & 5 & 5 & 8 & 26.3 & 26.3 & 0.63 \\
\hline \multicolumn{8}{|l|}{ Parawo. paradoxa } \\
\hline lectotype GPIG 389-100 & 21.8 & 1.7 & 11.3 & 12 & 7.8 & 55 & 0.94 \\
\hline
\end{tabular}


unfortunately, proved the presence of a rather wide and triangular umbilicus $(\mathrm{Pl} .4: 3,4)$ as in Parawo. paprothae. In order to preserve the latter taxon, established subsequently without knowledge of the paradoxa type series, a second. formerly unillustrated syntype. GPIG 389-100 (Pl. 4: $5-6)$, is designated as lectotype. The specimen is a rather complete, median-sized internal mould with a moderately large and round umbilical opening.

Remarks: As discussed above. the distinction between paradoxa and paprothae is not easy. especially in poorly preserved material. Internal moulds tend to have a wider umbilicus than specimens with preserved shell. It is the shape of the umbilical opening. not the relative umbilical width, that separates involute paprothae morphotypes from paradoxa. For this reason. the single Maider parawocklumeriid (MB.C.3061. Pl. 4: 7. 8) has been assigned to Parawo. paprothae rather than to paradoxa. Sutures of both taxa are identical. The relative whorl thickness varies considerably but strong compression as in Epiwo. applanata is normally not found. The latter species differ also in the convex course of constrictions and in the even smaller umbilicus: all characters allow a clear distinction of specimens lacking sutures. Shell homoeomorphy is more significant between Parawo paradoxa. Synwo. dunhevedensis, and Synwo. heterolobata.

Stratigraphical range: Paradoxa Subzone (UD VI- $\mathrm{C}_{2}$ ) to the top of the applanata Subzone

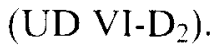

\section{Family Wocklumeriidae Schindewolf, 1937 Tardewocklumeria n. gen.}

Figs 7, 8a, 9

\begin{tabular}{|c|c|c|}
\hline e.p. & 1972 & $\begin{array}{l}\text { Mesowocklumeria (Czarnocki) Pajchlowa: } \\
101 \text { [nomen nudum: e.p. = Parawockli- } \\
\text { meria. e.p. = Triaclwmenia] }\end{array}$ \\
\hline v & 1981 & Synwocklumeria (?) Bogoslovskiy: 74 \\
\hline e.p. & 1989 & $\begin{array}{l}\text { Parawocklumeria Czarnocki: } 43 \text { Type spe- } \\
\text { cies: Parawocklumeria distributa Czar- } \\
\text { nocki. } 1989 \text {. }\end{array}$ \\
\hline
\end{tabular}

Type species: Parawocklumeria distributa Czarnocki, 1989.

Derivation of name: From lat. tardus = little, weak; due to its ancestral position in the Wocklumeriidae.

Diagnosis: Triangularly coiled throughout ontogeny and with strong constrictions. umbilicus small to moderately wide, sutures with rounded and wide median ventral lobe, rounded flank lobe (first ventral lobe) and small rounded subumbilical lobe. Sutural formula: $\mathrm{EAL}_{(\mathrm{c})}:$ ? $\mathrm{L}_{\mathrm{i}}\left(? \mathrm{I}_{1}-\mathrm{I}_{\mathrm{l}}\right)$.
Included species: Type species and Synwocklumeria (?) perplexa Bogoslovskiy, 1981.

Re marks: Bogoslovskiy's types have been examined in Moscow and nothing needs to be added to his descriptions. The new genus is distinguished from similarly coiled parawocklumerids by its wide and distinctive ventral lobe. Synwocklumeria is characterized by narrow lingulate to pointed mid-flank lobes and narrower, small ventral lobes. Tardewocklumeria n.gen probably is not just an intermediate phylogenetic stage between open-umbilicate Parawocklumeriidae and Wocklumeriidae but, based on the time difference of the two species included, it may represent a sidebranching lineage with closing umbilicus that reached (according to Bogoslovskiy in Simakov et al. 1983) in parallel with Parawocklumeria and Synwocklumeria the latest Wocklumian Wo. sphaeroides Zone.

Pajchlowa (1972) published determinations of J. Czarnocki in faunal lists and this included taxa which were not recognized subsequently in the posthumous monography of Czarnocki (1989). Various open umbilicate triangular clymenids (patens, primaeva, distorta, distributa) were combined in the nomen nudum Mesowocklumeria. Other taxa such as Kielcensia bohdanowiczi minima, Sphaerowocklumeria parva (= parra nom. vad.), Sphaero. nuciformis, Wo. accessa and Wo. globulosa remained uncommented and undescribed until now. It is not clear whether these names refer to material subsequently regarded as conspecific with other forms or whether the Polish faunas include additional Wocklumeriaceae which were left out in Czarnocki (1989).

Unfortunately, the dorsal lobes of Tardewocklumeria are still unknown. This leaves the two possibilities that the internal median saddle was or was not yet divided by a second I-lobe. Since outer sutures in the type-species are still rather reminiscent of Parawocklumeria, it is inferred that the same applies to dorsal parts.

Stratigraphical range: Parawo. paradoxa Zone (Kowala, Czarnocki 1989) to Wo. sphaeroides Zone (Kia Section, Simakov et al. 1983).

\section{Synwocklumeria mapesi n. sp.}

Figs 8b. 9. Pl. 4: 11, 12

Type: MB.C.2706, purchased at Erfoud and presented in 1997 by Prof. Royal Mapes, Athens, Ohio. The holotype is the only available specimen although various localities around the Jebel 
Aguelmous have been collected by the author in company with M. R. House (Southampton), V. Ebbinghausen (Odenthal), P. Bockwinkel (Leverkusen), S. Z. Aboussalam (MfN), D. Weyer (Magdeburg), R. Mapes, and others.

Type level and locality: Maïder, latest Famennian, most likely UD VI-C/D. The holotype was purchased together with other ammonoids that are typical for the Fezzou area. In the Erfoud region, haematitic UD VI faunas are only known from around the Jebel Aguelmous.

Diagnosis: A rather involute species of Synwocklumeria with broad dorsolateral saddle and narrow, rounded A-lobe.

Description: The holotype is a well preserved haematitic internal mould showing the last three septa and traces of healed dorsolateral shell damages. The conch is strongly tripartite, with deep constrictions, and resembles Parawo. paprothae (see PI. 4). The umbilicus is small but open, the cross-section subcircular with curved flanks and venter. Dimensions are given in Table 4.

Remarks: The new species resembles Synwo. kiensis but differs by details of the suture, especially by the rounded A-lobes, and by the rather wide and asymmetric inner flank saddle. Synwo. dunhevedensis and Synwo. heterolobata have a practically closed umbilicus, Synwo. angustilobata has a tongue-shaped A-lobe and is more convolute. Synwo. bashcirica is distinguished by its asymmetric and pointed midflank lobe.

\section{Kielcensia ingeniens $\mathbf{n} . \mathbf{s p .}$}

Figs $8 \mathrm{c}-$ d, 9, Pl. 4: 9, 10

Type: Holotype MB.C.2705, the only available specimen, purchased in Erfoud and presented by Prof. R. Mapes.

Type level and locality: Maïder, latest Famennian, most likely UD VI-C/D (see comments under Synwo. mapesi n.sp.).

Derivation of name: Due to the supposed ancestral position in the genus.

Diagnosis: A Kielcensia species with v-shaped adventitious lobe and narrow umbilicus of early stages that opens rapidly whilst coiling remains strongly tripartite.

Description: The holotype is a well-preserved haematitic mould with remains of the body chamber occupying about $2 / 3$ of the last whorl. The whorl cross-section is subcircular with rounded flanks and venter. The shell is strongly tripartite throughout ontogeny. The umbilicus opens during the last preserved whorl rapidly from ca. $10 \% \mathrm{dm}$ to $25 \% \mathrm{dm}$ and the umbilical opening forms a rather rounded ellipsoid. The conch shape resembles Parawo paprothae up to ca. $14 \mathrm{~mm} \mathrm{dm}$, and Parawo. distorta subsequently. Sutures show some variability but all have a pointed, narrow to moderately wide, vshaped A-lobe, a rounded, subumbilical lateral lobe, and a relatively small, rounded ventral lobe.

Remarks: The new species differs from all forms of $K$. bohdanoviczi by the shape of the Alobe and by the rapid opening of the umbilical spiral while the shell remains strongly constricted and tripartite. $K$. ingeniens n.sp. is morphologically intermediate between Synwocklumeria and $K$. bohdanoviczi. A second new Kielcensia from Oklahoma (Becker et al. in prep.) differs by unconstricted strongly triangular adult whorls.

\section{Wocklumeria sphaeroides sphaeroides (Richter, 1848)}

Figs $8 \mathrm{e}-\mathrm{f}, 9$, Pl. 5: 1-10

\begin{tabular}{|c|c|c|}
\hline$*+v$ & 1848 & $\begin{array}{l}\text { Goniatites sphaeroides Richter: } 34 \text {, pl. } 4 \\
\text { figs } 113-115\end{array}$ \\
\hline \multirow[t]{2}{*}{$\mathrm{v}$} & 1862 & Goniatites sphaeroides Gümbel: 311,322 \\
\hline & 1864 & Goniatites sphaeroides Richter: 614 \\
\hline$*$ & 1914 & $\begin{array}{l}\text { Wocklumeria Denckmanni Wedekind: } 10 \\
\text { [nom. nud.] }\end{array}$ \\
\hline $\mathrm{v}$ & 1916 & $\begin{array}{l}\text { Wocklumeria Denckmanni Schindewolf: } 36 \\
\text { [nom. nud.] }\end{array}$ \\
\hline \multirow[t]{3}{*}{$*+v$} & 1918 & $\begin{array}{l}\text { Wocklumeria Denckmanni Wedekind: } 172 \text {. } \\
\text { pl. XIX, figs } 18-21\end{array}$ \\
\hline & 1921 & Gattendorfia sphaeroides Schindewolf: 168 \\
\hline & $1923 b$ & $\begin{array}{l}\text { Wocklumeria Denckmanni Schindewolf: } \\
396\end{array}$ \\
\hline${ }^{*} v$ e.p. & 1924 & $\begin{array}{l}\text { Wocklumeria sphaeroides Schmidt: 121, } \\
\text { pl. } 6 \text {, figs } 16-17 \text { [e.p. = Parawocklumeria } \\
\text { sp. or sphaeroides plana] }\end{array}$ \\
\hline \multirow[t]{4}{*}{ *V e.p. } & 1924 & Wocklumeria distorta Schmidt: 121 \\
\hline & 1924 & $\begin{array}{l}\text { Wocklumeria sphaeroides Schindewolf: } \\
\text { 106-108, fig. 1b }\end{array}$ \\
\hline & 1924 & $\begin{array}{l}\text { Wocklumeria Denckmanni Schindewolf: } \\
\text { 106-108, fig. 1c }\end{array}$ \\
\hline & 1926 & $\begin{array}{l}\text { Wocklumeria Denckmanni Schindewolf: } \\
97 \text {, fig. } 1 \text { b }\end{array}$ \\
\hline *v e.p. & 1927 & $\begin{array}{l}\text { Wocklumeria sphaeroides Schmidt: 9, } 10 \\
\text { [e.p. = cf. aperta] }\end{array}$ \\
\hline * & 1927 & Wocklumeria sphaeroides Gallwitz: 497 \\
\hline \multirow[t]{2}{*}{ * } & 1929 & $\begin{array}{l}\text { Wocklumeria sphaeroides Peneau: } 189 . \\
\text { pl. } 12 \text {, fig. } 3 \mathrm{a}-\mathrm{c}\end{array}$ \\
\hline & 1929 & Wocklumeria denckmanni Lange: 30,31 \\
\hline$v$ non & 1932 & $\begin{array}{l}\text { Wocklumeria sphaeroides Paeckelmann: } 96 \\
\text { [fide Becker } 1997 \text { = sphaeroides plana] }\end{array}$ \\
\hline * & 1933 & Wocklumeria denckmanni Schmidt: 6 \\
\hline ?* & 1934 & Wocklumeria sp. Weber: 544,545 \\
\hline * & 1937 & $\begin{array}{l}\text { Wocklumeria sphaeroides Schindewolf: } 15 \text {, } \\
28,35,41,42,43,44,45,69-70 \text {, text- } \\
\text { fig. } 12 \text {, pl. } 1 \text {, figs } 12-15 \text {, pl. } 2 \text {, figs } 1-3\end{array}$ \\
\hline & 1938 & $\begin{array}{l}\text { Epiwocklumeria sphaeroides Paeckelmann: } \\
28\end{array}$ \\
\hline
\end{tabular}




\begin{tabular}{|c|c|c|}
\hline & 1950 & $\begin{array}{l}\text { Wocklumeria sphaeroides } \\
\text { 262: text-fig. } 226 \mathrm{f}\end{array}$ \\
\hline $\mathrm{v}$ & 1952 & Wocklumeria sphaeroides Schindewolf: 286 \\
\hline$\because v$ & 954 & $\begin{array}{l}\text { Wocklumeria sphaeroides Pfeiffer: } 58 \text {. } \\
\text { pl. VIII. figs } 5-6\end{array}$ \\
\hline$*$ & 1956 & $\begin{array}{l}\text { Wocklumeria Hollard \& Jaquemont: } 23 \\
\text { (footnote) }\end{array}$ \\
\hline$*$ e.p. & 1960 & $\begin{array}{l}\text { Wocklumeria sphaeroides Selwood: } \\
159-161 . \text { pl. 26. figs } 3-5 \text { [e.p. = sphaer- } \\
\text { oides plana and sphaeroides aperta] }\end{array}$ \\
\hline$*$ & 1960 & $\begin{array}{l}\text { Wocklumeria sphaeroides Petter: } 19-20 \text {. } \\
\text { text.-fig. G-G1. pl. II. figs } 7.8 .11\end{array}$ \\
\hline$*$ & 1960 & $\begin{array}{l}\text { Wocklameria sphaeroides Müller: } 148 \text {. } \\
\text { text-fig. } 199 \mathrm{~g}-\mathrm{h} . \quad \text { text-fig. } 201 \mathrm{~A} . \mathrm{b} . \\
\text { fig. } 201 \mathrm{~B}\end{array}$ \\
\hline cf. & 1963 & cf. Wocklumeria sp. Hollard: Tab. 1 \\
\hline$\because$ & 964 & $\begin{array}{l}\text { Wocklumeria sphaeroides Sun: } 807 \text {, pl. l. } \\
\text { figs 1-2 }\end{array}$ \\
\hline & 1965 & $\begin{array}{l}\text { Wocklumeria sphaeroides Sun \& Shen: } 36 \text {. } \\
37.3946-47 \text {. pl. I. figs } 5-10\end{array}$ \\
\hline & 966 & Wockhumeria sphaeroides Babin: 381 \\
\hline ? & 70 & Wocklumeria? sp. Hollard: 924 \\
\hline$*$ & 979 & $\begin{array}{l}\text { Wocklameria sphaeroides Clausen et al: } \\
59\end{array}$ \\
\hline$*$ & 1979 & $\begin{array}{l}\text { Wocklumeria sphaeroides Weyer: } 99 \text {. pl. } 1 . \\
\text { fig. } 4\end{array}$ \\
\hline *v e.p. & 1980 & $\begin{array}{l}\text { Wocklumeria sphaeroides Bartzsch \& } \\
\text { Weyer: } 35.37 \text {. fig. } 21.3 \text { [non fig. } 2 \mathrm{a} . \mathrm{b}= \\
\text { sphaeroides plana] }\end{array}$ \\
\hline$*$ & 1981 & Wocklameria sphaeroides Korn: tab. I \\
\hline$*$ & 1981 & $\begin{array}{l}\text { Wockhmeria sphaeroides Ruan: } 6.111 . \\
\text { pl. } 28 \text {. figs } 9-16\end{array}$ \\
\hline$*$ & 1981 & $\begin{array}{l}\text { Wocklumeria sphaeroides Bogoslovskiy: } \\
\text { 69. pl. VII. figs 5-6 }\end{array}$ \\
\hline$\because ?$ & 1981 & ?Wocklumeria sp. Whiteley: 189 \\
\hline$*$ & 1982 & $\begin{array}{l}\text { Wocklumeria sphateroides Bartzsch \& } \\
\text { Weyer: } 33\end{array}$ \\
\hline & 1982 & $\begin{array}{l}\text { Wockhumeria sphaeroides Paproth \& } \\
\text { Streel: } 40.45 \text {. text-fig. } 17 \text {. tab. } 6\end{array}$ \\
\hline & 1983 & $\begin{array}{l}\text { Wocklumeria sphaeroides Simakov et al.: } \\
\text { tab. } 2\end{array}$ \\
\hline & 984 & $\begin{array}{l}\text { Wocklumeria sphatoroides Korn in Clausen } \\
\text { \& Leuteritz: } 50\end{array}$ \\
\hline$*_{v}$ & 1984 & $\begin{array}{l}\text { Wockhumeria sphaeroides Becker et al.: } \\
189\end{array}$ \\
\hline $\mathrm{v}$ & 885 & Wocklumeria sphacroides Becker: 33 \\
\hline$?$ & 985 & Wocklumeria sp. Gong et al.: 11 \\
\hline${ }^{*} \mathrm{v}$ & 1986 & $\begin{array}{l}\text { Wocklumeria sphaeroides Paproth et al.: } 4 . \\
\text { fig. } 19\end{array}$ \\
\hline & 1986 & $\begin{array}{l}\text { Wocklumeria sphaeroides Bartzsch \& } \\
\text { Weyer: } 149 \text {. pl. II. fig. } 7\end{array}$ \\
\hline$*$ & 1987 & Wocklumeria sp. Yu et al.: pl. 1. figs 5-6 \\
\hline$? *$ & 1988 & $\begin{array}{l}\text { Wocklumeria sp. Flajs \& Feist: } 55 \text {, text- } \\
\text { fig. } 5\end{array}$ \\
\hline$* \mathrm{*} v$ & 1988 & $\begin{array}{l}\text { Wocklumeria sphatoroides Becker: } 198 . \\
\text { 199. text-fig. 3. pl. 1, figs 5-6 }\end{array}$ \\
\hline * & 1988 & $\begin{array}{l}\text { Wockhumeria sphaeroides Korn: 215. text- } \\
\text { fig. } 1\end{array}$ \\
\hline & 988 & $\begin{array}{l}\text { Wockhumeria sphaeroides Ruan: } 256 . \mathrm{pl} \text {. } \\
65 \text {, fig. } 2 \mathrm{a} \text {. b }\end{array}$ \\
\hline * & 1989 & $\begin{array}{l}\text { Wockhumeria sphaeroides Czarnocki: } 26 . \\
28.30 .39 \text {. pl. IX. figs } 11-12.14 \text {. pl. X. } \\
\text { figs } 4-8.82-17 \text {. pl. XLI. fig. } 8 \text {. pl. XLII. } \\
\text { figs } 2-6\end{array}$ \\
\hline & $89 a$ & $\begin{array}{l}\text { Wocklumeria sphaeroides Clausen et al.: } \\
\text { 358. fig. } 3\end{array}$ \\
\hline & & Clausen et al.: 175 \\
\hline ? & & $a \mathrm{sp} .1$ \\
\hline$*$ & 1991 & Wocklumeria sphaeroides Korn: 557. fig. 2 \\
\hline $\mathrm{V}$ & 1993 & $\begin{array}{l}\text { Wocklumeria sphaeroides Becker et al.: } 23 \text {. } \\
31,38,50.55 \text {. text-figs } 18.24 .46\end{array}$ \\
\hline * & & $\begin{array}{l}\text { Wocklumeria sphaeroides Korn: } 582 \text {. } \\
\text { figs } 3.5\end{array}$ \\
\hline
\end{tabular}

\begin{tabular}{|c|c|c|}
\hline$*$ & 1993 & Wocklumeria sp. Korn: fig. 9 \\
\hline s: & 1994 & $\begin{array}{l}\text { Wocklameria sphaeroides Luppold et al: } \\
16-17,21,23,29,35, ? 41\end{array}$ \\
\hline * & 1994 & $\begin{array}{l}\text { Wocklumeria sphaeroides Korn et al.: } 116 \text {, } \\
122-123 \text {, text-figs } 5-6,16 \mathrm{~d}, 21\end{array}$ \\
\hline 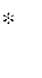 & 1995 & $\begin{array}{l}\text { Wocklumeria sphaeroides Bartzsch et al.: } \\
24\end{array}$ \\
\hline & $1995 \mathrm{a}$ & $\begin{array}{l}\text { Wocklumeria sphaeroides Korn: } 162 \text {, text- } \\
\text { fig. } 6\end{array}$ \\
\hline${ }^{*} \mathrm{~V}$ & 1996 & $\begin{array}{l}\text { Wocklumeria sphaeroides Becker: } 23,24 \text {, } \\
\text { text-figs } 2,3 \mathrm{a}\end{array}$ \\
\hline$* v$ & 1998 & $\begin{array}{l}\text { Wocklumeria sphaeroides Bartzsch et al.: } \\
44,45 \text {, text-figs } 3.3-3.4\end{array}$ \\
\hline & 1999 & $\begin{array}{l}\text { Wocklumeria sphaeroides Korn: } 153 \text {, } \\
\text { fig. } 3\end{array}$ \\
\hline
\end{tabular}

Types: BGR X4895 (Pl. 5: 1, 2) is selected here as the lectotype of Wo. sphaeroides. This median-sized Richter (1848) syntype is tectonically somewhat distorted and does not show sutures but agrees well with his plate IV, figures 113 and 114. A second syntype (BGR X4896) is even stronger distorted but shows a mature single constriction at rather small size (ca. $28 \mathrm{~mm}$ $\mathrm{dm})$. Wedekind's types of Wo. denckmanni have been lost in the collection of Göttingen University. MB.C.1725 from the Wocklum type locality, leg. by Wedekind and deposited in Berlin, is regarded as another syntype and designated here as lectotype (Pl. 5: 5, 6).

Remarks: Large collections from the Rhenish Massif and from Thuringia give insights into the intraspecific variability of Wo. sphaeroides. Selwood (1960) plotted shell parameters (umbilication, relative whorl widths) and found no clear distinction between the three Wocklumeria species recognized by Schindewolf (1937). In the present study, Schindewolf's taxa are kept arbitrarily at subspecies level to allow easy characterisation of shell form of specimens. Wo. sphaeroides aperta is a rather rare morphotype, and Wo. sphaeroides plana is not as abundant as the typical subspecies at German localities. All three forms, however, have identical time ranges within the sphaeroides Zone.

Wocklumeriids from North Africa are mostly much smaller-sized than European populations. Originally (Becker 1997b) it was thought that they represent a new micromorphic species or subspecies. The maximum size of wocklumeriids correlates strongly with the size at which the morphological transformation from constricted triangular to normal rotund coiling takes place. Rhenish Wo. sphaeroides (all subspecies) frequently reach between 30 and $48 \mathrm{~mm} \mathrm{dm}$ and specimens may still be constricted at 25 to $28 \mathrm{~mm} \mathrm{dm}$ (sphaeroides sphaeroides: MB.C. 1720 and MB.C.2218.1-5, sphaeroides plana: MB.C.1721.4 and MB.C.2217.1-5). An inter- 
Table 4

Dimensions of some Wocklumeriidae.

\begin{tabular}{|c|c|c|c|c|c|c|c|}
\hline species/specimen & $\mathrm{dm}$ & uw & wh & ww & uw $\%$ & $w w \%$ & $\mathrm{wh} / \mathrm{ww}$ \\
\hline \multicolumn{8}{|l|}{ Synwo. mapesi n.sp. } \\
\hline holotype MB.C.2706 & 16.5 & 2 & 6.7 & 10.4 & 12.1 & 63 & 0.64 \\
\hline \multicolumn{8}{|l|}{ Kielcensia ingeniens n.sp. } \\
\hline holotype MB.C.2705 & 16.3 & 3 & 6.6 & 9.8 & 18.4 & 60.1 & 0.67 \\
\hline holotype MB.C.2705 & ca. 13.5 & 1.5 & ca. 6.5 & ca. 9 & ca. 11 & ca. 67 & 0.72 \\
\hline \multicolumn{8}{|l|}{ Wo. sphaeroides sphaeroides } \\
\hline lectotype X4895 & ca. 30 & 9.2 & 9.5 & 17.7 & ca. 30 & ca. 60 & 0.54 \\
\hline lectotype Wo. denckmanni & 34.5 & 10.4 & 13.5 & ca. 23 & 30.1 & 66.7 & 0.59 \\
\hline \multicolumn{8}{|l|}{ Wo. sphaeroides plana } \\
\hline neotype MB.C.1721.1 & ca. 41 & 15 & 14 & 17 & ca. 36.5 & ca. 41.5 & 0.82 \\
\hline paratype MB.C.1721.3 & 37.3 & 12 & 12.7 & 19 & 32.2 & 50.9 & 0.67 \\
\hline \multicolumn{8}{|l|}{ Wo. sphaeroides aperta } \\
\hline neotype MB.C.2220.1 & 33.8 & 17 & 7.2 & 22.3 & 50.3 & 66 & 0.32 \\
\hline \multicolumn{8}{|l|}{ Epiwo. applanata } \\
\hline MB.C.2701 & 27.5 & 0 & 14 & 10.4 & 0 & 44.1 & 1.17 \\
\hline MB.C. 2229 & 20 & 0 & 11 & ca. 8 & 0 & ca. 40 & ca. 1.35 \\
\hline MB.C. 2221.2 & 13.6 & 0 & 7 & 6 & 0 & 51.5 & 1.35 \\
\hline
\end{tabular}

mediate morphotype between sphaeroides sphaeroides and sphaeroides plana from Hasselbachtal (Beds 106-113N, MB.C.3067, Pl. 5: 9, 10) has a last concave constriction as late as at $31 \mathrm{~mm} \mathrm{dm}$. At Oberrödinghausen, Wo. sphaeroides from the lower part (Beds 5 to 3 ) of UD VI-D reach only 30 to $33 \mathrm{~mm} \mathrm{dm}$; bigger specimens were exclusively collected from Beds 1 and 2. This suggests a morphological gradient in time, a hypermorphic trend within the zone, caused by the addition of whorls during median (triangular) ontogenetic stages. Uniform facies conditions speak against an alternative interpretation as ecophenotypical change. Since the species is much more abundant towards the top of its zone (peak abundance in the applanata Subzone: more than 650 specimens in the Berlin collection), the lack of large morphotypes at older levels may perhaps be based on a sampling artefact. However, Hasselbachtal collections gave a similar size trend with specimens bigger than $37 \mathrm{~mm} \mathrm{dm}$ found (so far) first in Bed Ha $103 \mathrm{bN}$ (MB.C.2703). Other large-sized Wo. sphaeroides have been found at the top of the Wocklum Limestone at Oese (MB.C.2724 = Oc 1705), Drewer (MB.C.1683, 1748: $45 \mathrm{~mm} \mathrm{dm}$ ) and at Borkewehr (MB.C.2227.1: $47 \mathrm{~mm} \mathrm{dm}$ ).

The smallest fully rotund (last whorl unconstricted and not subtriangular) Wo. sphaeroides sphaeroides from the Rhenish Massif are between 21.5 (MB.C.1718.2) and $24 \mathrm{~mm}$ in diameter (MB.C.2219.1) and come from Bed 1 at Oberrödinghausen. Such morphotypes are rather rare. There is an even smaller rotund Wo. sphaeroides plana (MB.C.2215.1: at $20 \mathrm{~mm} \mathrm{dm}$ ) from the same bed. Similar forms have not yet been found in the lower part of the sphaeroides Zone, neither at Oberrödinghausen, nor at Hasselbachtal. Therefore, it seems that there was a heterochronic trend towards a size dimorphism in the species which, as in Kielcensia, could be expressed taxonomically.

A large Thuringian population from around Fischersdorf does not show the Rhenish pattern. Large morphotypes of Wo. sphaeroides sphaeroides are much rarer (BGR Z568: $45 \mathrm{~mm} \mathrm{dm}$, Z584: $40 \mathrm{~mm} \mathrm{dm}$ ) but there are more early rotund specimens such as BD 523 with only $12.5 \mathrm{~mm} \mathrm{dm}$. Another early rotund specimen (Z7559) is illustrated on Plate 5 (Figs 7 and 8). The lectotype (Pl. 5: 1,2) with ca. $30 \mathrm{~mm} \mathrm{dm}$ is rather typical fore the Saalfeld area. Small normally coiled sphaeroides plana occur as well (BGR Z673.2: ca. $21 \mathrm{~mm}$ ). At Fezzou and Lambidia in the Maïder, triangular coiling may disappear both in Wo. sphaeroides sphaeroides (MB.C.3066) and in sphaeroides plana (MB.C.2707, Pl. 5: 17, 18; MB.C.2708) before $15 \mathrm{~mm} \mathrm{dm}$. The largest adults (MB.C.3064.1-2) of the region reach ca. $30 \mathrm{~mm}$ dm. Petter (1960) illustrated from Southern Algeria both small, early rotund sphaeroides plana and larger (max. $35 \mathrm{~mm} \mathrm{dm}$ ) sphaeroides sphaeroides. This shows that normal-sized wocklumeriids did spread to North Africa but very large-sized morphotypes (> $40 \mathrm{~mm} \mathrm{dm}$ ) are not yet documented.

A very large specimen $(49 \mathrm{~mm} \mathrm{dm})$ showing the typical terminal umbilical widening and sin- 
gle mature apertural constriction was illustrated by Selwood (1960) from Cornwall. Small-sized morphotypes, by contrast. have not been mentioned. From the Urals only normal-sized (up to $35 \mathrm{~mm} \mathrm{dm}$ ) Wo. sphaeroides have been described so far (Bogoslovskiy 1981). Czarnocki (1989) illustrated from Poland normal to moderately large-sized ( $\max .40 \mathrm{~mm} \mathrm{dm}$ ) material. From Guizhou, only juvenile and triangularly coiled Wo. sphaeroides have been described so far (Sun \& Shen 1965, Ruan 1981). As mentioned above, this leaves the possibility that they belong to a synwocklumeriid ancestor. From Guangxi (Ruan 1988) there is only a poorly preserved specimen.

In summary, Selwood's (1960) observation of extreme intraspecific shell variability is fully confirmed. Small early rotund. normal-sized and very large (late triangular) morphotypes, however, show distinctive differences in stratigraphical and spatial distribution. This indicates continuing heterochronic developments but intermediates (mostly from Thuringia) suggest that speciation had not been completed before the abrupt global extinction at the peak of distribution, caused by the sudden anxoxic pulse of the global Hangenberg Event (Fig. 12).

Stratigraphical range: Wo. sphaeroides to Epiwo. applanata Subzones (UD VI-D to VI-D $_{2}$ ).

\section{Wocklumeria sphaeroides plana Schindewolf, 1937}

$$
\text { Pl. 5: 13-18 }
$$

\begin{tabular}{|c|c|c|}
\hline$v$ & 1932 & $\begin{array}{l}\text { Wocklameria sphaeroides Paeckelmann: } 96 \\
\text { [fide Becker 1997] }\end{array}$ \\
\hline$+v$ & 1937 & $\begin{array}{l}\text { Wocklameria plana Schindewolf: } 70-71 \text {. } \\
\text { pl. 2. figs } 4-6\end{array}$ \\
\hline & 1954 & $\begin{array}{l}\text { Wocklumeria plana Pfeiffer: 58. pl. VIII. } \\
\text { fig. } 7\end{array}$ \\
\hline & 1954 & $\begin{array}{l}\text { Wocklumeria plana Petter: 12. } 1960 \\
\text { Wocklumeria plana Petter: } 20 \text {, text-fig. 2F. } \\
\text { pl. Il, figs } 6.9 .11-13\end{array}$ \\
\hline & 1960 & Wocklumeria plana Müller: text-fig. 201 A.a \\
\hline e.p. & 1960 & $\begin{array}{l}\text { Wocklumeria sphaeroides } \\
159-161\end{array}$ \\
\hline ?c.p. & 1963 & cf. Wocklwmeria sp. Hollard: tab. 1 \\
\hline ?e.p. & 1967 & Wocklumeria? sp. Hollard: 924 \\
\hline 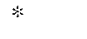 & 1979 & Wocklumeria plana Clausen et al.: 59 \\
\hline$\therefore$ & 1980 & Wocklumeria plana Barizsch \& Weyer: 37 \\
\hline *e.p. & 1980 & $\begin{array}{l}\text { Wocklameria sphaeroides Bartzsch \& } \\
\text { Weyer: fig, } 2 \mathrm{a}, \mathrm{b}\end{array}$ \\
\hline$*$ & 1984 & $\begin{array}{l}\text { Wocklumeria plana Korn in Clausen \& } \\
\text { Leuteritz: } 50\end{array}$ \\
\hline${ }^{*} \mathrm{~V}$ & 1986 & Wockhumeria plana Paproth et al.: 4 \\
\hline & 1986 & Wocklumeria plana Bartzsch \& Weyer: 1 \\
\hline & $1989 b$ & Wocklumeria plana Clausen et al.: 175 \\
\hline$v$ & 1993 & $\begin{array}{l}\text { Wocklumeria plana Becker et al.: } 31 \text {, te } \\
\text { fig. } 19\end{array}$ \\
\hline $\mathrm{v}$ & 1996 & $\begin{array}{l}\text { Wocklumeria sphaeroides plana Becker: } \\
\text { 24. text-fig. 3b }\end{array}$ \\
\hline$v^{\prime}$ & 1997 & $\begin{array}{l}\text { Wocklumeria sphateroides plana } \\
33-34\end{array}$ \\
\hline
\end{tabular}

Type: Schindewolf's holotype has been lost. A moderately preserved large (max. $\mathrm{dm}>40 \mathrm{~mm}$ ) paratype from Bed 1 of Oberrödinghausen (MB.C.1721.1, Pl. 5: 13-14) which shows sutures is here designated as neotype.

Remarks: As outlined above, Wo. plana probably represents only an intraspecific morphological variant of sphaeroides. This is supported by very similar stratigraphical and spatial distribution as well as by identical patterns of size distributions. BGR Z581 (Bartzsch Collection) is an exceptional specimen with four rather than three constrictions on the last whorl. MB.C.2707 (Pl. 5: 17-18) from Fezzou shows a mature shallow constriction already at $20 \mathrm{~mm} \mathrm{dm}$. The largest specimen with $48 \mathrm{~mm} \mathrm{dm}$ is MB.C.2216.1 from Oberrödinghausen (Bed 1).

\section{Wocklumeria sphaeroides aperta Schindewolf, 1937}

Pl. 5: 11,12

\begin{tabular}{|c|c|c|}
\hline \multirow[t]{2}{*}{+} & 1937 & $\begin{array}{l}\text { Wocklumeria aperta Schindewolf: } 71-72 \text {, } \\
\text { text-fig. } 14 \text {, pl. } 2 \text {, figs } 7-9\end{array}$ \\
\hline & 1950 & $\begin{array}{l}\text { Wocklumeria aperta Schindewolf: } 262 \text {, } \\
\text { text-fig. } 226 \mathrm{e}\end{array}$ \\
\hline * & 1954 & Wocklumeria aperta Petter: 12 \\
\hline e.p. & 1960 & $\begin{array}{l}\text { Wocklumeria } \\
159-161\end{array}$ \\
\hline$\because$ & 1980 & Wocklumeria aperta Bartzsch \& Weyer: 37 \\
\hline & 1982 & $\begin{array}{l}\text { Wocklumeria aperta Bartzsch \& Weyer: } \\
\text { fig. } 12\end{array}$ \\
\hline ;: & 1989 & $\begin{array}{l}\text { Wocklumeria aperta Czarnocki: } 39-40 \text {, pl. } \\
\text { IX, fig. } 15 \text {, pl. X, fig. } 11\end{array}$ \\
\hline$; ;$ & 199 & Wocklumeria aperta Becker et al.: 38 \\
\hline$: ;$ & 1996 & $\begin{array}{l}\text { Wocklumeria sphaeroides aperta Becl } \\
23,24\end{array}$ \\
\hline
\end{tabular}

Type: Schindewolf's holotype and all other figured specimens have been lost. Four preserved paratypes are all rather poorly preserved and the most typical fragmentary specimen, neotype MB.C.2220.1, is not suitable for photographic illustration. The characteristic dimensions are given in Table 4.

Remarks: Wo sphaeroides aperta is rather rare and is not yet known as micromorphic morphotype. Petter (1954) mentioned the form from Algeria but did not describe it subsequently (Petter 1960). Selwood (1960) found in his Cornwall population intermediates but no specimens that fully fit the definition of the subspecies.

Stratigraphical range: Sphaeroides Subzone (Hasselbachtal, ?Oberrödinghausen) to applanata Subzone (e.g., Oberrödinghausen, Oese). 


\section{Epiwocklumeria applanata (Wedekind, 1918)}

Fig. 9, Pl. 4: 13-16

\begin{tabular}{|c|c|c|}
\hline$*+$ & 1918 & $\begin{array}{l}\text { Wocklumeria paradoxa var. applanata We- } \\
\text { dekind: } 173, \text { pl. } 19 \text { fig. } 15 \text {. }\end{array}$ \\
\hline * & 1929 & Wocklumeria applanata Lange: 30 \\
\hline$*$ & 1937 & $\begin{array}{l}\text { Epiwocklumeria applanata Schindewolf: } \\
73 \text {, text-fig. } 13 \text {, pl. } 2 \text {, figs } 10-12\end{array}$ \\
\hline & 1960 & $\begin{array}{l}\text { Epiwoclumeria applanata Müller: } 148, \\
\text { text-fig. } 199 \mathrm{i}-\mathrm{k}\end{array}$ \\
\hline * & 1989 & $\begin{array}{l}\text { Epiwocklumeria applanata Czarnocki: } 28 \text {, } \\
40 \text {, pl. X, figs } 1-3,9-10 \text {; pl. XLV, fig. } 5\end{array}$ \\
\hline
\end{tabular}

Type: The holotype (monotype) of Wedekind (1918) from Wocklum has been lost in the collection at Göttingen. Currently, there is no trace of topotypes collected later by Lange (1929). The new Hasselbachtal specimen (MB.C.2701, Pl. 4: 15-16) showing the suture is the best currently available German representative of the species and genus and a potential neotype. MB.C.2221.1 is the original to Schindewolf's (1937) text-figure 13 and displays inner sutures.

Description: In every aspect the new Hasselbachtal and Drewer (MB.C.2229, Pl. 4: 13-14) specimens conform with those figured by Wedekind, Schindewolf and Czarnocki. It seems that there was little intraspecific variation in the compressed whorl form and in the course of the suture. This proves that large intraspecific conch variability does not apply to all advanced Wocklumeriaceae.

Stratigraphical range: Latest Wocklumian, Epiwo. applanata Subzone (UD VI-D2).

\section{Acknowledgements}

Initial parts of this study were supported by a habilitation grant of the Deutsche Forschungsgemeinschaft. Important specimens were generously provided by R. Mapes (Athens) and by V. Ebbighausen (Odenthal). S. Z. Aboussalam (MfN) collected new Wocklumeria material from southern Morocco. Mrs. W. Harre conducted photographic work, E. Stenzel prepared numerous specimens, Mrs. E. Sievert and Mr. J.-P. Mendau (all MfN) produced ink drawings. Mrs. M. Tilling assisted in the editorial correction of the manuscript. W. Lindert (BGR Spandau) made important types available, V. Menner (Moscow) enabled the examination of Russian specimens. The author is also indebted to M. R. House (Southampton) and D. Weyer (Berlin) for comments and review.

\section{References}

Babin, C. 1966. Mollusques Bivalves et Céphalopodes du Paléozoique armoricain. Etude systématique. Essai sur la phylogénie des Bivalves. Esquisse paléoécologie. - 471 pp., Commission de Administration, Brest.

Bartzsch, K. \& Weyer, D. 1980. Neue Ostracoda aus der Wocklumeria-Stufe (Oberdevon) von Saalfeld im Thü- ringischen Schiefergebirge. - Abhandlungen und Be richte für Naturkunde und Vorgcschichte XII (2): 34-51.

Bartzsch, K. \& Weyer, D. 1982. Zur Stratigraphie des Unter tournai (Gattendorfia-Stufe) von Saalfeld im Thüringischen Schiefergebirge. - Abhandlungen und Berichte für Naturkunde und Vorgeschichte XII (4): 3-54.

Bartzsch, K., Blumenstengel, H. \& Weyer, D. 1995. Ein neues Devon/Karbon-Grenzprofil am Bergaer Antiklinorium (Thüringer Schiefergebirge) - eine vorläufige Mitteilung. - Geowissenschaftliche Mitteilungen von Thüringen $\mathbf{3}$ : $13-29$.

Bartzsch, K., Hahne, K. \& Weyer, D. 1998. Der HangenbergEvent (Devon/Karbon-Grenze) im Bohlen-Profil von Saalfeld (Thüringisches Schiefergebirge). - Abhandlungen und Berichte für Naturkunde 20:37-58.

Becker, R. T. 1985. Devonische Ammonoideen aus dem Raum Hohenlimburg-Letmathe (Geologisches Blatt 4611 Hohenlimburg). - Dortmunder Beiträge zur Landeskunde, naturwissenschaftliche Mitteilungen 19: 19-34.

- 1988. Ammonoids from the Devonian-Carboniferous boundary in the Hasselbach Valley (Northern Rhenish Slate Mountains). - Courier Forschungs-Institut Senckenberg 100: 193-213.

1992. Zur Kenntnis von Hemberg-Stufe und AnnularaSchiefer im Nordsauerland (Oberdevon, Rheinisches Schiefergebirge, GK 4611 Hohenlimburg). - Berliner geowissenschaftliche Abhandlungen E3: $3-43$.

- 1993a. Analysis of ammonoid palaeobiogeography in relation to the global Hangenberg (terminal Devonian) and Lower Alum Shale (Middle Tournaisian) events. - Annales de la Societe géologique de Belgique 115 (2): 459-473.

- 1993b. Anoxia, eustatic changes, and Upper Devonian to lowermost Carboniferous global ammonoid diversity. Systematic Association, Special Volume 47: 115-163. Clarendon Press, Oxford.

- 1993c. Stratigraphische Gliederung und AmmonoideenFaunen im Nehdenium (Oberdevon) von Europa und Nord-Afrika. - Courier Forschungs-Institut Senckenberg $\mathbf{1 5 5}, 405 \mathrm{pp}$.

- 1995. Taxonomy and Evolution of Late Famennian Tornocerataceae (Ammonoidea) - Berliner geowissenschaftliche Abhandlungen E16: 607-643.

- 1996. New faunal records and holostratigraphic correlation of the Hasselbachtal D/C-Boundary Parastratotype. Annales de la Société géologique de Belgique, M. Streel Festschrift 117 (1): 19-45.

- 1997a. Eine neue und älteste Glatziella aus dem höheren Oberdevon des Nordsauerlandes (Rheinisches Schiefergebirge). - Berliner geowissenschaftliche Abhandlungen E25: $31-41$.

- 1997b. Ursprung und Evolution der Dreiecksclymenien und ihrer Verwandten (Wocklumeriina n. suborder; oberes Oberdevon). - Terra Nostra 97/6: 26-27.

Becker, R. T. \& Kullmann, J. 1996. Paleozoic Ammonoids in Space and Time. In Landman, N. H., Tanabe, K. \& Davis, R. A. (eds). Ammonoid Paleobiology, Topic in Geobiology 13: 711-753, New York (Plenum Press).

Becker, R. T., Bless, M. J. M., Brauckman, C., Friman. L., Higgs, K., Keupp, H., Korn, D., Langer, W., Paproth. E.. Rachebeuf, P., Stoppel, D., Streel, M. \& Zakowa, H. 1984. Hasselbachtal, the section best displaying the Devonian-Carboniferous boundary beds in the Rhenish Massif (Rheinisches Schiefergebirge). - Courier Forschungsinstitut Senckenberg 78: 181-192.

Becker, R. T., Korn, D., Paproth, E. \& Streel, M. 1993. Beds near the Devonian-Carboniferous boundary in the Rhenish Massif, Germany. - Excursion Guidebook, Subcommission on Carboniferous Stratigraphy (SCCS), 86 pp.

Becker, R. T., Bockwinkel, J., Ebbighausen, V. \& House, M. R. 1999. Jebel Mrakib, Anti-Atlas (Morocco), a potential Upper Famennian Substage Boundary Stratotype Section. In El Hassani, A. \& Tahiri, A. (eds) SDS - IGCP 421 
Morocco Meeting: April 23 $3^{\text {rd }}$ - May $1^{\text {st }} 1999$. Excursion Guidebook, Part I: Tafilalt and Maider (eastern Anti-Atlas), 91-107.

Bogoslovskiy, B. I. 1955. Biloclymeniidae fam. nov. - Doklady Akademia Nauk SSSR 104: 134-137. [In Russian].

- 1969. Devonski Ammonoidei. I. Agoniatity. - Trudy Paleontologicheskogo Institut 124: 341 pp.

1976. Early ontogeny and origin of clymenid ammonoids. - Paleontologicheskiy Zhurnal 1976 (2): 4l-50. [In Russian].

1977. On the family Miroclymeniidae Schindewolf 1924. - Paleontologicheskiy Zhurnal 1977 (4): 47-57. [In Russian].

- 1981. Devonskie Ammonoidei. III. Klimeny. - Trudy Paleontologicheskogo Institut, 191: $122 \mathrm{pp}$.

Bogoslovskaya, M. F., Mikhailova, I. A. \& Shevyrev, A. A 1990. Ammonoid System. In Menner, V.V. (ed.). Sistematika i filogenyia bespoevonochnyikh: 69-98. Akademyia Nauk SSSR. Moscow.

Breitkreuz, C. 1986. Das Paläozoikum von Nord-Chile. Geotektonische Forschung 70: $88 \mathrm{pp}$.

Checa, A.. Company, M. Sandoval, J. \& Weitschat. W. 1996. Covariation of morphological characters in the Triassic ammonoid Czekanowskires rieberi. - Lethaia 29 (3): $225-236$.

Chegodaev, L. D. \& Puporev, Y. B. 1979. The Devonian/Carboniferous boundary in the Northern Caucasus and its paleontologic substantiation. In Simakov. K.V. (ed.) Biostratigraphy and fauna of the Devonian-Carboniferous boundary deposits, Pacific Science Congress. Chabarovsk, August 1979. Field Excursion Guidebook. IX. Supplement 8: 247-256. [In Russian].

Chermnykh, V. A., Kochetkova. N. Y.. Pazukhin, V. N., Lipyna, O. A.. Nemirovskaya. T. I. \& Tiasheva. I. D. 1988 The Devonian/Carboniferous boundary deposits in the Northern and Polar Ural. In The Devonian Carboniferous boundary at the territorry of the USSR: 145-151. Nauka i Technico. Minsk. [In Russian].

Clausen. C.-D. \& Leuteritz. K. 1984. Erläuterungen zu Blatt 4516 Warstein. - Geologische Karte von NordrheinWestfalen 1: 25 000. Erläuterungen. $155 \mathrm{pp}$.

Clausen. C.-D., Korn. D. \& Uffenorde. H. 1979. Das Devon Karbon-Profil am alten Schießstand bei der Bilstein-Höhle (Blatt 4515 Hirschberg. Warsteiner Sattel. Rheinisches Schiefergebirge). - Aufschluss. Sonderband 29: 47-68.

Clausen, C.-D., Korn. D.. Luppold. F. W. \& Stoppel. D. 1989a. Untersuchungen zur Devon/Karbon-Grenze auf dem Müssenberg (Nördliches Rheinisches Schiefergebirge). - Bulletin de la Société belge de Géologie 98 (3/4) $353-369$.

Clausen. C.-D.. Leuteritz. K.. Ziegler. W. \& Korn. D. 1989b. Ausgewählte Profile an der Devon/Karbon-Grenze im Sauerland (Rheinisches Schiefergebirge). - Fortschritte in der Geologie des Rheinlandes und von Westfalen 35 : $161-226$.

Croneis. C. 1930. Triangular nepionic Coiling in Carboniferous Ammonoids. - Science 77 (1873): 534-535.

Czarnocki, J. 1989 (posthumous). Klimenie gór Swietokrzyskich. - Prace Panstwowego Instytutu Geologicznego 127: $141 \mathrm{pp}$

Denckmann, A. 1901. Uber das Oberdevon auf Blatt Balve. - Jahrbuch der königlichen preußischen geologischen Landesanstalt. 21 (f. 1900): 1-19.

Druchshits, V. V., Bogoslovskaya. M. F. \& Doguzhaeva, L. A 1976. Evolution of septal necks in the ammonoidea. Paleontologicheskiy Zhurnal 1976 (1): 41-56. [In Russian].

Dzik. J. 1991. A monograph of the clymeniid ammonites. Acta Palaeontologica Polonica 36 (3): 343-344.

Flajs. G. \& Feist. R. 1988. Index conodonts. trilobites and environment of the Devonian-Carboniferous Boundary beds at La Serre (Montagne Noire. France). - Courier Forschungs-Institut Senckenberg 100: 53-107.
Frech. F. 1902. Über devonische Ammoneen. - Beiträge zur Paläontologie und Geologie von Österreich-Ungarn 14: $27-112$

- 1904. Über die explosive Entwicklung der oberdevonischen Ammoneen. - Zeitschrift der deutschen geologischen Gesellschaft 56. Protokolle: 164-167.

Gaertner. H. R. von 1931. Geologie der Zentralkarnischen Alpen. - Denkschriften der kayserlichen Akademie der Wissenschaften Wien, mathematisch-naturwissenschaftliche Klasse 102: 113-149.

Gallwitz. H. 1927. Stratigraphische und tektonische Untersuchungen an der Devon-Carbon-Grenze des Sauerlandes. - Jahrbuch der preußischen geologischen Landesanstalt 48: $487-527$.

Gong Xie-Bao. Huang Han-Duo, Wang Chey-Yuan, Wei Wei-Lie, Wong Jin-Tao, Wu Xiang-He, Yin Bao-An \& Zhang Ziang-Tian 1985. Devonian - Carboniferous transitional beds of South China. - Guidebook, Chinese Academy of Geological Sciences, Guizhou Bureau of Geology and Mineral Resources: $31 \mathrm{pp}$.

Gümbel, C. W. 1862. Revision der Goniatiten des Fichtelgebirges. - Neues Jahrbuch für Mineralogie, Geologie und Paläontologie für 1862: 85-165.

Hollard, H. 1963. Une tableau stratigraphiques des Devonién du Sud de l'Anti-Atlas. - Notes des Service Géologique du Maroc 23 (173): 105-109.

1970. Sur la transgression dinantienne au Maroc Présaharien. - Compte Rendu 6e Congrès Internationale de Stratigraphie et Géologie de Carbonifère, Sheffield 1967 III: $923-936$

Hollard. H. \& Jacquemont, P. 1956. Le Gothlandien, le Dévonien et le Carbonifère des region du Dra et du Zemoul. - Notes des Services Geologiques du Maroc 15 (135): 7-33.

House, M. R. 1959. Upper Devonian ammonoids from North-West Dartmoor, Devonshire. - Proceedings of the Geologists Association 70 (4): 315-321.

- 1963. Devonian ammonoid successions and facies in Devon and Cornwall. - Quarterly Journal of the Geological Society of London 119: 1-27.

- 1970. On the origin of the clymenid ammonoids. - Palaeontology 13 (4): 664-676.

- 1981. On the origin, classification and evolution of the early Ammonoidea. - Systematics Association, Special Volume 18: 4-36, Academic Press, London and New York.

House. M. R. \& Butcher, N. E. 1973. Excavations in the Upper Devonian and Carboniferous rocks near Chudleigh, South Devon. - Transactions of the Royal Geological Society of Cornwall 20 (3): 199-220.

House, M. R. Gordon, M. Jr. \& Hlavin, W. J. 1986. Late Devonian ammonoids from Ohio and adjacent states. Journal of Paleontology 60 (1): 126-144.

Hyatt. A. 1884. Genera of fossil cephalopods. - Proceedings of the Boston Society for Natural History 22: 253-338.

Ji Qiang., Wie J.-Y., Wang Z.-J., Wang Shi-Tao., Sheng HuaiBin. Wang H.-D., Hou J.-P., Xiang Li-Wen, Feng R.-L. \& Fu G.-M. 1989. The Dapoushang Section. - 165 pp., Science Press., Beijing.

Kegel, W. 1922. Abriss der Geologie der Lahnmulde. - Abhandlungen der preußischen geologischen Landesanstalt, neue Folge 86: $81 \mathrm{pp}$

Kind. N. V. 1944. Goniatiti y klymenii zapodnogo sklona Mugodzharskikh gornego. - Uchenye Sapiski LGU, No. 70, Seria Geologo-Pochvennykh Nauk 11: $137-166$.

Korn, D. 1981. Ein neues Ammonoideen-führendes Profil an der Devon-Carbon-Grenze im Sauerland (Rhein. Schiefergebirge). - Neues Jahrbuch für Geologie und Paläontologie, Monatshefte 1981 (9): $513-526$.

- 1988. On the stratigraphical occurence of Cymaclymenia evoltuta (H. Schmidt, 1924) at the type locality. - Courier Forschungs-Institut Senckenberg 100: 215-216. 
- 1991. Threedimensionally preserved clymeniids from the Hangenberg Black Shale of Drewer (Cephalopoda, Ammonoidea; Devonian-Carboniferous boundary, Rhenish Massif). - Neues Jahrbuch für Geologie und Paläontologie, Monatshefte 1991 (9): 553-563.

- 1992a. Relationship between shell form, septal construction and suture line in clymeniid cephalopods (Ammonoidea; Upper Devonian). - Neues Jahrbuch für Geologie und Paläontologie, Abhandlungen 185 (1): 115-130.

- 1992b. Ammonoideen aus dem Devon/Karbon-Grenzprofil an der Grünen Schneid (Karnische Alpen, Österreich). - Jahrbuch der Geologischen Bundesanstait 135 (1) 7-19.

- 1993. The ammonoid faunal change near the DevonianCarboniferous boundary. - Annales de la Sociéte Géologique de Belgique 115 (2): 581-593.

- 1995a. Paedomorphosis of ammonoids as a result of sealevel fluctuations in the Late Devonian Wocklumeria Stufe. - Lethaia 28: 155-165.

- 1995b. Impact of environmental perturbations on heterochronic development in Palaeozoic ammonoids. In $\mathrm{McNa}$ mara, K. J. (ed.). Evolutionary Change and Heterochrony: 245-260, Wiley \& Sons, New York.

- 1999. Famennian Ammonoid Stratigraphy of the Maïder and Tafilalt (Eastern Anti-Atlas, Morocco). - Abhandlungen der Geologischen Bundesanstalt, 54: 147-179.

Korn, D. \& Luppold, F. W. 1987. Nach Clymenien und Conodonten gegliederte Profile des oberen Famenniums im Rheinischen Schiefergebirge. - Courier Forschungs-Institut Senckenberg 92: 199-223.

Korn, D., Clausen, C.-D., Belka, Z., Leuteritz, K., Luppold, F. W., Feist, R. \& Weyer, D. 1994. Die Devon/KarbonGrenze bei Drewer (Rheinisches Schiefergebirge). Geologie und Paläontologie in Westfalen 29: 97-147.

Lange, W. 1929. Zur Kenntnis des Oberdevons am Enkeberg und bei Balve (Sauerland). - Abhandlungen der preußischen geologischen Landesanstalt, neue Folge 119: 132 pp.

Librovich, L. S. 1957. O nekotorych voych gruppach goniatitov iz Kamennougol'nich otloszenij SSSR. - Ezhegod vsesoyuzu paleontologiya obshitch 16: 246-273.

Lewowicki, S. 1959. Fauna wapieni klimeniowych z Dzikowca klodzkiego. - Byuletin Instytut Geologiczny 146 (N7): $73-118$.

Luppold, F. W., Clausen, C. D., Korn, D. \& Stoppel, D. 1994. Devon/Karbon-Grenzprofile im Bereich von RemscheidAltenaer Sattel, Warsteiner Sattel, Briloner Sattel und Attendorn-Elsper Doppelmulde (Rheinisches Schiefergebirge). - Geologie und Paläontologie in Westfalen 29: $7-69$.

Matern, H. 1931. Das Oberdevon der Dill-Mulde. - Abhandlungen der preußischen geologischen Landesanstalt, Neue Folge 134: 147 pp.

Miller, A. K. 1938. Devonian Ammonoids of America. Geological Society of America, Special Paper 14: 262 pp.

Müller, A. H. 1960. Lehrbuch der Paläozoologie, Band II Invertebraten, Teil 2 Mollusca 2 - Arthropoda 1. 855 pp., Fischer, Jena.

Müller, K. J. 1956. Cephalopodenfauna und Stratigraphie des Oberdevons von Schleiz und Zeulenroda in Thüringen. Beihefte zum Geologischen Jahrbuch 20: 93 pp.

Münster, G. Graf von. 1842. Nachtrag zu den Versteinerungen des Übergangskalkes mit Clymenien von Oberfranken. - Beiträge zur Petrefacten-Kunde 5: 112-128.

Nalivkina, A. K. 1953. Verkhnedevonski goniatity i klimeni Mugodzhar. - Trudy VNIGRI, nova seria 72: 60-125.

Nemirovskaya, T., Chermnykh, V. A., Kononova, L. I. \& Pazukhin, V. N. 1993. Conodonts of the Devonian-Carboniferous boundary section, Kozhim, Polar Urals, Russia. Annales de la Société géologique de Belgique 115 (2) 629-647.

Over, J. D. (1992). Conodonts and the Devonian-Carboniferous boundary in the upper Woodford Shale, Arbuckle
Mountains, South-Central Oklahoma. - Journal of Paleontology 66 (2): 293-311.

Paeckelmann, W. 1924. Das Devon und Karbon der Umgebung von Balve in Westfalen. - Jahrbuch der preußischen geologischen Landesanstalt 44: 51-97.

- 1932. Über den Nachweis der Wocklumeria-Zone im Oberdevon des Bergischen Landes. - Berichte über die Versammlung des niederrheinischen geologischen Vereins für 1930/1931: $96-100$.

- 1936. Geologische Karte von Preußen 1:25 000, Blatt Madfeld und Erläuterungen, Lieferung 341.79 pp., PreuBische Geologische Landesanstalt, Berlin.

- 1938. Geologische Karte von Preußen und benachbarten Ländern, Lieferung 349, Erläuterungen zu Blatt Balve, Nr. 2655. - 69 pp., Preußische Geologische Landesanstalt, Berlin.

Pajchlowa, M. 1972. Fauna of the Devonian. In Rühle, W. (ed.). Geology of Poland, Catalogue of Fossils, Part 1, Palaeozoic: $292 \mathrm{pp}$

Paproth, E. \& Streel, M. 1982. Devonian - Carboniferous transitional beds of the northern "Rheinisches Schiefergebirge". - Working Group on the Devonian/Carboniferous Boundary, Guidebook: 63 pp., Liége.

Paproth, E., Becker, R. T., Clausen, C. D., Kompa, R., Korn, D. \& Stoppel, D. 1986. Field trip to the Late Devonian outcrops in the Northern Rheinisches Schiefergebirge (Federal Republic of Germany): 32 pp., Aachen.

Paproth, E., Feist, R. \& Flajs, G. 1991. Decision on the Devonian-Carboniferous boundary stratotype. - Episodes 14 (4): $331-336$

Peneau, J. 1929. Études stratigraphiques et paléontologiques dans le SE du Massif Armoricain (Synclinal de Saint-Julien-de Vouvantes). - Bulletin de la Société des Sciences Naturelles de l'Ouest de la France, 4e série 8: 300 pp.

Perna, E. 1914. Die Ammoneen des oberen Neodevon vom Ostabhang des Südurals. - Trudy Geologicheskogo Komiteta 99: 114 pp. [In Russian with German summary].

Petersen, M. S. 1975. Upper Devonian (Famennian) Ammonoids From the Canning Basin, Western Australia. Journal of Paleontology, Memoir 8: 55 pp.

Petter, G. 1954. Famennien terminal aux environs de BeniAbbes (Sahara Nord-Occidental). - Bulletin de la Société Géologique de France, 6e série 4: 11-16.

- 1960. Clymenies du Sahara. - Publication du Service de la Carte Géologique de l'Algerie (nouvelle série), Paléontologie, Mémoire 6: $76 \mathrm{pp.}$

Pfeiffer, H. 1954. Der Bohlen bei Saalfeld/Thüringen. - Beihefte zur Zeitschrift Geologie 11: $105 \mathrm{pp}$.

Price, J. D. \& Korn, D. 1989. Stratigraphically important clymeniids (Ammonoidea) from the Famennian (Late Devonian) of the Rhenish Massif, West Germany. - Courier Forschungs-Institut Senckenberg 110: 257-294.

Renz, C. 1914. Neue Arten aus dem Clymenienkalk von Ebersdorf in Schlesien. - Jahrbuch der preußischen geologischen Landesanstalt 34: 99-129.

Richter, R. 1848. Beitrag zur Paläontologie des Thüringer Waldes. Die Grauwacke des Bohlens und des Pfaffenberges bei Saalfeld. I. Fauna. 48 pp., Arnoldi, Dresden, Leipzig.

- 1864. Clymenien und Goniatiten des Fichtelgebirges. Neues Jahrbuch für Mineralogie, Geologie, Geognosie und Petrefactenkunde 32: 612-615.

Ruan Yi-Ping 1981. Devonian and earliest Carboniferous ammonoids from Guangxi and Guizhou. - Memoirs of Nanjing Institut of Geology and Palaeontology, Academia Sinica 15: $140 \mathrm{pp}$. [In Chinese with English summary].

- 1988. Ammonoids. In Yu Chang-Min (ed.). DevonianCarboniferous Boundary in Nanbiancun, Guilin, China Aspects and Records: 251-262, Science Press, Beijing.

Ruzhencev, V. E. 1957. Filogeneticeskaja sistema paleozojskich ammonoidei. - Byulletin Moskovskogo ot-va ispyt prirody otd Geologia 32 (2): 59-64. 
Sanz-Lopez. J.. Garcia-Lopez. S.. Montesinos. J. R. \& Arbizu. M. 1999. Biostratigraphy and sedimentation of the Vidrieros Formation (middle Famennian - lower Tournaisian) in the Gildar-Montó unit (northwest Spain). - Bolletino della Società Palaeontologica Italiana $37(2-3)$ : 393-\$06.

Schindewolf. O. H. 1916. Uber das Oberdevon von Gattendorf bei Hof a. S. - Zeitschrift der deutschen geologischen Gesellschaft 68 (Monatsberichte 1-3): 30-39.

- 1921. Versuch einer Paläogeographie des europäischen Oberdevonmeeres. - Zeitschrift der deutschen geologischen Gesellschaft 73: 137-223.

- 1923a. Beiträge zur Kenntnis des Palaeozoikums in Oberfranken. Ostthüringen und dem sächsischen Vogtlande. I. Stratigraphie und Ammoneenfauna des Oberdevons von Hof a. d. Saale. - Neues Jahrbuch für Mineralogie. Geologie und Paläontologie. Beilage-Band 49: 250-357. $393-509$

- 1923b. Entwurf einer natürlichen Systematik der Clymenoidea. - Zentralblatt für Mineralogie. Geologie und Paläontologie, für 1923: $23-30.59-64$.

- 1924. Bemerkungen zur Stratigraphie und Ammoneenfauna des Saalfelder Oberdevons. - Senckenbergiana 6 (3/4): 95-113.

- 1925. Entwurf einer Systematik der Perisphincten. Neues Jahrbuch für Mineralogie. Geologie und Paläontologie. Beilage-Band 52B: 309-343.

- 1926. Zur Kenntnis der Devon-Karbon-Grenze in Deutschland. - Zeitschrift der deutschen Geologischen Gesellschaft. Abhandlungen 78: 88-133.

- 1928. Prinzipienfragen der biologischen Systematik. - Paläontologische Zeitschrift 9 (1/3): 122-169.

- 1934. Über eine oberdevonische Ammoneen-Fauna aus den Rocky Mountains. - Neues Jahrbuch für Mineralogie. Geologie und Paläontologie. Abteilung B 72: 331 - 350.

- 1937. Zur Stratigraphie und Paläontologie der Wocklumer Schichten. - Abhandlungen der preußischen geologischen Landesanstalt. Neue Folge 178: $132 \mathrm{pp}$.

- 1949. Zur Phylogenie der Clymenien (Cephalop.. Ammon.). - Neues Jahrbuch für Mineralogie. Geologie und Paläontologie. Monatshefte. Abteilung $B$ für 1949: 197-209.

- 1950. Grundfragen der Paläontologie. - $506 \mathrm{pp}$. $32 \mathrm{pls}$ Schweizerbart. Stuttgart.

- 1952. Über das Oberdevon und Unterkarbon von Saalfeld in Ostthüringen. Eine Nachlese zur Stratigraphie und Ammoneen-Fauna. - Senckentergiana 32 (5/6) 281-306.

- 1955. Zur Taxonomie und Nomenklatur der Clymenien: Ein Epilog. - Neues Jahrbuch für Mineralogie. Geologie und Paläontologie. Monatshefte. 1955 (10): 417-429.

Schmidt. H. 1921. Über Goniatiten - eine Revision ihrer Systematik mit Beifügung neuer Beobachtungen. - Centralblatt für Mineralogie. Geologie und Paläontologie 1921: $538-544$.

- 1922. Das Oberdevon-Culm-Gebiet von Warstein i. W und Belecke. - Jahrbuch der preußischen geologischen Landesanstalt 41: 254-339.

- 1924. Zwei Cephalopodenfaunen an der Devon-Carbongrenze im Sauerland. - Jahrbuch der preußischen geologischen Landesanstalt 44: 98-171.

- 1927. Die Wocklumeria-Zone bei Warstein und Belecke. - Sitzungsberichte des naturhistorischen Vereins von Preußen, der Rheinlande und Westfalens 1927: 9-11.

1933. Der Kellerwaldquarzit mit einer Beschreibung seiner Fauna und der aus der Tanner Grauwacke. - Geologische und Paläontologische Abhandlungen. neue Folge 19 (5): $297-349$

Selwood. E. B. 1960 Ammonoids and trilobites from Upper Devonian and Lowest Carboniferous of the Launceston area of Cornwall. - Palaeontology 3 (2): 153-185.
Selwood, E. B., Edwards, R. A., Simpson, S., Chesher, J. A., Hamblin. R. J. O. Henson, M. R., Riddols, B. W. \& Waters. R. A. 1984. Geology of the county around Newton abbot. - Memoir, 1 : 50000 geological sheet 339, new series. British Geological Survey, $212 \mathrm{pp}$.

Sheng Huai-Bin 1985. Ammonoids. In Hou Hong-Fei, Ji Quiang. Wu Xiangho, Xiang Jian-Fei, Wang Shi-Tao, Gao Lianda. Sheng Huai-Bin, Wei Jia-Yong \& Turner, S. (eds). Muhua sections of Devonian-Carboniferous boundary beds: $85-90$. Geological Publishing House, Beijing.

Simakov. K. V., Bogoslovskiy, B. I., Gagiev, M. K., Kononova. L. I.. Kochetkova. N. M., Kusina, L. F., Kulagina, E. I.. Onoprienko. U. I., Pazukhin, V. N., Radinova, E. P., Rasina. T. P.. Reitlinger. E. A., Simakova, L.V. \& Yanoulatova. M. G. 1983. Biostratigrafiya pogranichnikh otloszheniy Devona i Karbona. Kharakteristikye pogranichnikh otloseheniy Devona i Karbona Mugodzhar. 51 pp., Akademia Nauk. Magadan.

Sun Yun-Chu 1964. On the lower boundary of the Carboniferous system of South China. - Compte Rendu 5e Congrés International de Stratigraphie et de Géologie du Carbonifère. Paris 1963, 2: 807-812

Sun Yun-Chu \& Shen. Yao-Ting 1965. On the late Upper Devonian fauna of the Wocklmmeria beds of South Kweichow and its stratigraphical significance. - Professional Paper of the Academy of Geological Sciences, Mineralogy and Geology. B, I: 33-108. [In Chinese with English summary].

Tietze. E. 1871. Über die devonischen Schichten von Ebersdorf unweit Neurode in der Grafschaft Glatz. - Palaeontographica 19: 103-158.

Trueman. A. E. 1941. The ammonite body-chamber, with special reference to the buoyancy and mode of life of the living ammonite. - Quarterly Journal of the Geological Society of London 96: 339-383.

Weber. H. 1934. Das Oberdevon der Attendorn-Elsper Doppelmulde. - Zeitschrift der deutschen geologischen Gesellschaft 86: $537-574$.

Wedekind, R. 1908. Die Cephalopodenfauna des höheren Oberdevon am Enkeberg. - Neues Jahrbuch für Mineralogie. Geologie und Paläontologie 26: 565-634.

- 1914. Monographie der Clymenien des Rheinischen Gebirges. - Abhandlungen der Gesellschaft für Wissenschaften Göttingen. mathematisch-physikalische Klasse, neue Folge 10. N1: 73 pp.

- 1918. Die Genera der Palaeoammonoidea (Goniatiten) - Palaeontographica 62: 85-184.

Westermann, G. 1975. A model for origin, function and fabrication of fluted cephalopod septa. - Paläontologische Zeitschrift 49: 235-253.

Weyer. D. 1972. Rozmanaria, ein neues Rhynchonellida-Genus aus dem europäischen Oberfamenne (Brachiopoda Oberdevon), - Geologie 21 (1): 84-99.

- 1979. Biostratigraphy of the Devonian-Carboniferous boundary in the German Democratic Republic. - Compte Rendu 8 e Congrès Internationale de Stratigraphie et Géologie de Carbonifère, Moscou 1975, 2: 97-104.

- 1981. Glatziella RENZ 1914 (Ammonoidea, Clymeniida) im Oberdevon von Thüringen. - Hallesches Jahrbuch für Geowissenschaften 6: $1-12$.

- 1995. Heterocorallia aus Famenne-Cephalopodenkalken im Rheinischen Schiefergebirge und Tafilalt. - Abhandlungen und Berichte für Naturkunde 18: 103-135.

Whiteley. M. J. 1981. The faunas of the Viverdon Down area. south-east Cornwall. - Proceedings of the Usher Society 5: $186-193$.

Yu Chang-Min. Wang Chey-Yuan, Ruan Yi-Ping, Yin BaoAn. Li Zheng-Liang \& Wei. Wei-Lic 1987. A desirable section for the Devonian-Carboniferous boundary stratotype in Guilin, Guangxi, South China. - Scientia Sinica, series B. 30 (7): $715-765$. 
Plate 1. 1-2, Platyclymenia (Varioclymenia) pompeckji Wedekind, MB.C.1729, Nie Brickwork Quarry, NE section, lower part of UD III-C, lateral and adoral views, showing straight ribbing and the typical flat venter, $\times 1.5 .3-4$, Platyclymenia (Varioclymenia) pompeckji Wedekind, MB.C.1730, topotype, Enkeberg, UD III-C, leg. RTB in 1985, lateral and adoral views, specimen showing the mature reduction and change in ribbing as well as a strange trumpet-like terminal apertural widening with coarse growth ornament, $\times 1$. 5-6, Platyclymenia (Varioclymenia) brevicostata (Münster), MB.C.1735, Enkeberg. Bed 9, leg. Paeckelmann in 1925 (det. Platy. cf. pompeckji), UD III-C, lateral and adoral views, showing straight ribbing and the convex venter, $\times$ 2. 7, Platyclymenia (Varioclymenia) humilis Schindewolf, MB.C.1736 (see Becker 1985: fig. 3a), Nie Brickwork Quarry, old, now burried section, Bed 9, middle part of UD III-C, lateral view, showing concave ribbing similar as in Soliclymenia, $\times 3.8-9$, Pleuroclymenia kasachstanica (Kind), MB.C.1731, purchased topotype (perhaps even a syntype), western Mugodzhar Mts, UD III-C, lateral and adoral views, showing the early loss of ribs and a typical ventral mould constriction, $\times 1.5$. 10-12, Pleuroclymenia costata (Lange), MB.C.1266, Kirschhofen near Weilburg, topotype of Pleuro. crassissima Schindewolf. UD IV-A, lateral view, $\times 2.5$, showing rursiradiate ribbing; ventral view, $\times 2.5$, showing ventral termination of ribs and mould constrictions; adoral view after removal of the last half whorl, $\times 3.13-14$, Pleuroclymenia costata (Lange), MB.C.1806.1, small fragmentary specimen from the Hauern near Braunau, Kellerwald, leg. Schindewolf in 1931, UD IV-A, lateral and ventral views, showing details of the ornament, $\times 3$

Plate 2. 1-2, Pleuroclymenia mutabilis (Czarnocki), MB.C.1807.2, Hauern near Braunau, UD IV-A, leg. Schindewolf in 1931, lateral and ventral views, showing the gradual disappearance of ribbing and ventral ornament with a shallow sinus of growth lines, $\times 2.5$. 3-4, Pleuroclymenia cyclocostata (Czarnocki), MB.C.1732, large specimen, Nie Brickwork Quarry, old section (Becker 1985), Bed 14, top part of UD III-C, lateral and adoral views, $\times 1.5$. 5-6, Hexaclymenia hexagona (Wedekind). MB.C.1805.1, topotype, Enkeberg, leg. Lotz \& Denckmann, UD III-C, lateral and ventral views, showing growth ornament and the typical whorl form. 7-8, Progonioclymenia aegoceras (Frech), MB.C.3068.1, Ense near Wildungen, Kellerwald. leg. Denckmann in 1893, UD V, lateral and ventral views, showing the strong and straight ribbing of mature whorls, $\times 1.5$. 9-10, Progonioclymenia aegoceras (Frech), MB.C.3063.1, Hauern near Wildungen, Kellerwald, leg. Denckmann in 1897. UD V, lateral and oblique view, showing the marginal rim terminating straight ribs (the lack of ornament of inner whorls is based on erosion), $\times$ 3.5. 11-12, Glatziella tricincta Schindewolf, BGR Spandau, X5673, holotype (see Schindewolf 1937: pl. 3, fig. 1a, b), Quarry at Ebersdorf (now Dzikowiec), UD VI-B, lateral and ventral views, showing strong ribbing and the marginal double furrow, $\times$ 4. 13-14, Glatziella minervae (Renz), MB.C.2202.1, fragmentary specimen, Oberrödinghausen Railway Cut. Bed 10 (see Schindewolf 1937: 17), UD VI-C , $_{1}$ lateral view, showing strong flank ribs and deep spiral furrows, $\times 4$; ventral views, showing concave ribs terminating at the furrows and the very broad, keeled venter, $\times 3.15-16$, Glatziella diensti Renz, BGR Spandau X6575, holotype (see Schindewolf 1937: pl.3, fig. 3, text-figs 17, 18), cut at median plane, Quarry at Ebersdorf (now Dzikowiec), UD VI-B, lateral and ventral views, resembling Glat. minervae, but venter not as broad

Plate 3. 1-2, 'Clymenia' nana Münster, MB.C. 3062, Jebel Aguelmous at Lambidia (Loc. 123), Maïder, leg. V. Ebbighausen, UD V-A, lateral and ventral views, showing extremely evolute and smooth coiling and marked ventral constrictions, $\times 3.3-4$. Kamptoclymenia endogona Schindewolf, MB.C.1813.1, neotype, Oberrödinghausen Railway Cut, Bed 7, leg. Schindewolf in 1934, upper part of UD VI-C 1 , lateral, $\times 3$, and ventral views, $\times 4$. 5-6, Kamptoclymenia trigona Schindewolf, MB.C.1751, neotype, Oberrödinghausen Railway Cut, Bed 8, leg. Schindewolf in 1934, upper part of UD VI-C $C_{1}$, lateral and ventral views, showing the extremely evolute and depressed whorl form, $\times 4.7-8$, Triaclymenia triangularis Schindewolf, MB.C. 1815 , the poorly preserved neotype, Oberrödinghausen Railway Cut, Bed 10, leg. Schindewolf in 1934, lower part of UD VI-C 1 . lateral and ventral views, showing the typical, compressed cross-section, $\times 2.5$. 9-10, Parawocklumeria patens Schindewolf. MB.C.1757, Oberrödinghausen Railway Cut, Bed 7, leg. by Schindewolf in 1933 (see Schindewolf 1937: 16, 94), upper part of UD VI-C ${ }_{1}$, lateral and ventral views, $\times$ 4. 11-12, Parawocklumeria patens Schindewolf, MB.C.2713, original of Müller (1956: pl.2, fig. 27), Geipel Quarry, Bed 17, Thuringia, UD VI-C $_{1}$, lateral and adoral views, $\times$ 4. 13-14, Parawocklumeria ?patens Schindewolf, MB.C.1769, Oberrödinghausen Railway Cut, Bed 9, see Schindewolf (1937: 16, 94), lower part of UD VI-C 1 . lateral and ventral views, $\times 4$. 15, Triaclymenia triangularis Schindewolf, MB.C.1817, paratype of Schindewolf (1937: 91), Oberrödinghausen Railway Cut, Bed 9, leg. Schindewolf in 1934, lower part of UD VI-C , $_{1}$, ventral view, showing mature subtriangular cross-section and shallow sinus of growth ornament. 16-17, Parawocklumeria distorta (Tietze), MB.C.1768.3, Oberrödinghausen Railway Cut, Bed 9, leg. Schindewolf in 1930-32 (see Schindewolf 1937: 16, 95), lower part of UD VI-C 1 . lateral, $\times 3$, and adoral views, $\times 2$, showing shell form that resembles juvenile Wo. sphaeroides

Plate 4. 1-2, Parawocklumeria paprothae Korn, MB.C.2714.2, Oberrödinghausen Railway Cut, Bed 1, leg. Schindewolf. UD VI- $\mathrm{D}_{2}$, lateral and adoral views, showing a relative wide umbilicus, $\times 1.5$. 3-4, Parawocklumeria paprothae Korn. GPIG $389-$ 78a, somewhat corroded specimen, syntype of Parawo. paradoxa Wedekind (1918: pl. 19, fig. 17). Burg near Wocklum. UD VI-D, lateral view, showing a rather wide umbilicus, and ventral view, $\times 2$. 5-6, Parawocklumeria paradoxa, GPIG 389-100. lectotype, previously unfigured syntype of Wedekind (1918), Burg near Wocklum, UD VI-D, lateral view, showing small rounded umbilicus of internal mould, $\times 2$ 2. 7-8, Parawocklumeria paprothae Korn, MB.C.3061, leg. V. Ebbighausen, Fezzou, Maïder, UD VI-C/D, lateral and adoral views, showing typical sutures with rounded ventral saddle, crowding of last septa despite small size, and a small but markedly triangular umbilical opening, $\times 5.9-10$, Kielcensia ingeniens $\mathrm{n}$. sp., MB.C.2705. holotype, purchased specimen from the Maïder, UD VI-?D, lateral and ventral views, showing sutures and the rapid opening of the umbilicus during the last preserved whorl, $\times 3$. 11-12, Synwocklumeria mapesi n. sp., MB.C.2706, holotype, purchased specimen from the Maider, UD VI-?D, lateral and adoral views, showing the small open umbilicus and sutures, $\times 3.13-14$. Epiwocklumeria applanata (Wedekind), MB.C.2229, Provincial Quarry at Drewer, Section WA, Bed 93, leg. RTB 1998, UD VI-D ${ }_{2}$, lateral and adoral views, showing typical convex constrictions and compressed cross-section, $\times 2.5$. 15-16, Epiwocklumeria applanata (Wedekind), MB.C.2701, Hasselbachtal, Bed 113aN, leg. RTB 1997, UD VI-D 2 , lateral and ventral vicws, $\times 2$

Plate 5. Wocklumeria sphaeroides div. ssp. 1-2, Wo. sphaeroides sphaeroides (Richter), BGR Spandau, X4895, lectotype (typical morphotype), original of Richter (1848: 34, pl. 4, figs 113-114), Bohlen near Saalfeld, Thuringia, UD VI-D. lateral and ventral views, showing broad whorl profile and relative small umbilicus, $\times 1.5$. 3-4, Wo. sphaeroides sphaeroides (Richter). MB.C.912, triangular stage of typical morphotype, original of Schindewolf (1937: pl. 2, fig. 1), Oberrödinghausen Railway Cut. Bed 1, leg. Schindewolf in 1926 , UD VI-D 2 , lateral and adoral views, $\times 2.5$. 5-6, Wo. sphaeroides sphaeroides (Richter), MB.C.1725, previously unillustrated syntype and lectotype of Wo. denckmanni Wedekind, Burg near Wocklum, UD VI-D. lateral and adoral views, showing broad whorls and moderately wide umbilicus, $\times 1.5$. 7-8, Wo. sphaeroides sphaeroides (Richter), BGR Spandau, Z559, micromorphic and earl rotund morphotype, Fischersdorf W near Saalfeld, Thuringia, leg. K. 
Bartzsch, UD VI-D, lateral and ventral views. $\times 2.5 .9-10$. Intermediate between Wo. sphaeroides sphaeroides and sphaeroides plana, MB.C.3067, late triangular morphotype. Hasselbachtal. Beds 106-113N, leg. RTB 1999, UD VI-D, lateral and adoral views, $\times$ 1.5. 11-12, Wo. sphaeroides aperta Schindewolf. MB.C.1631 (= Oc 1984), original of Becker (1996), Hasselbachtal, Bed $94 \mathrm{~N}$, lower part of UD VI-D , lateral and adoral views, showing rather wide umbilicus and broad, extremely depressed cross-section, $\times 1.5$. 13-14, Wo, sphaeroides plana Schindewolf, MB.C.1721.1, neotype (syntype of Schindewolf 1937: 15, 70, 71), large-sized morphotype, Oberrödinghausen Railway Cut, Bed 1, UD VI- $D_{2}$, lateral and adoral views, showing umbilicus that opens suddenly on the last half whorl, and the rather compressed cross-section, $\times 1.5$. 15-16, Wo. sphaeroides plana Schindewolf, MB.C.2704.1. normal. triangular juvenile. Hasselbachtal. Bed 113aN, lower part of UD VI-D 2 , lateral and adoral views, $\times 2$. 17-18, Wo. sphaeroides plana Schindewolf. MB.C.2707, micromorphic, early rotund morphotype, Fezzou, Maïder, leg. RTB in 1985, UD VI-D. lateral and adoral views, $\times 2$ 


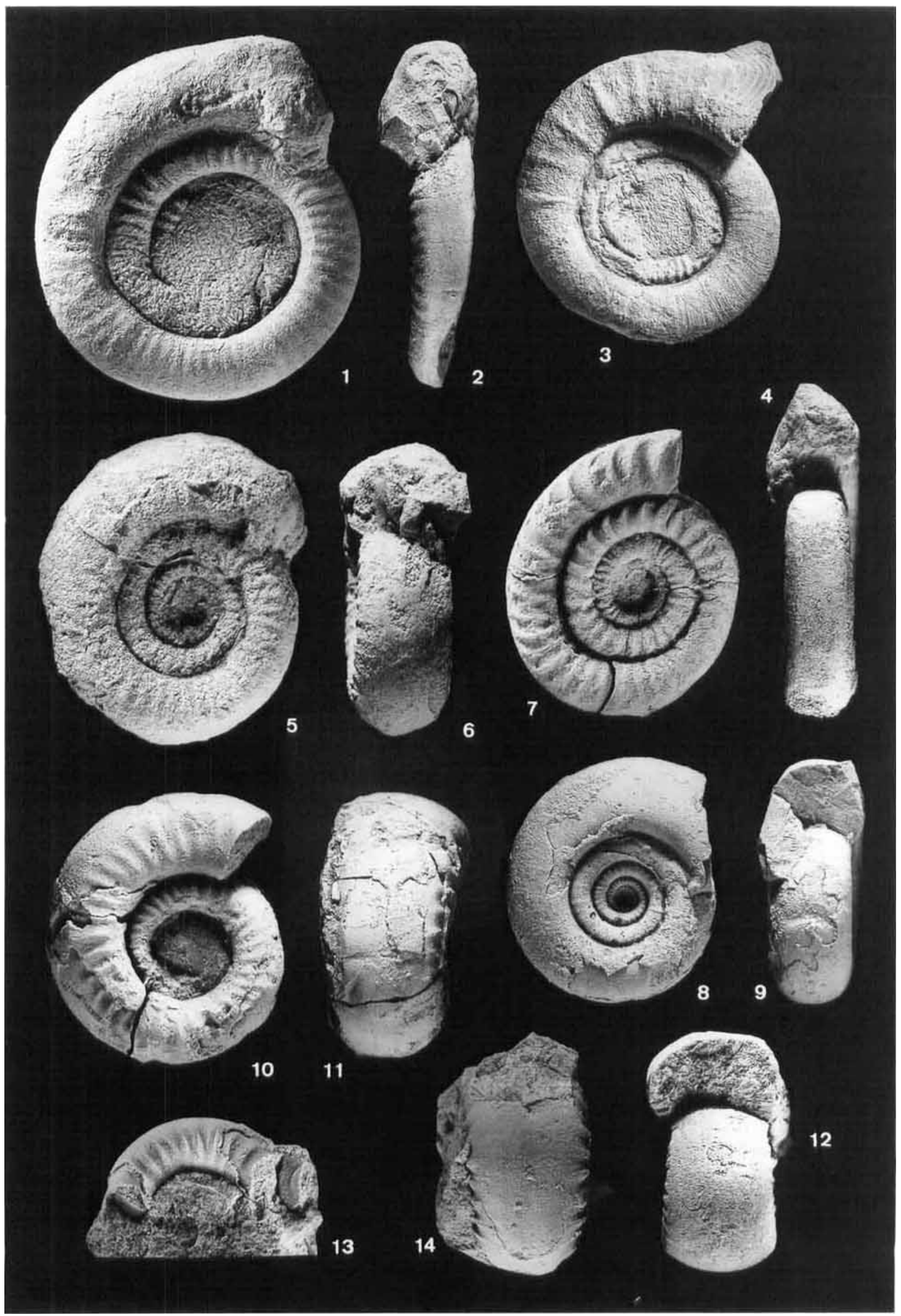

Plate 1 




Plate 2 


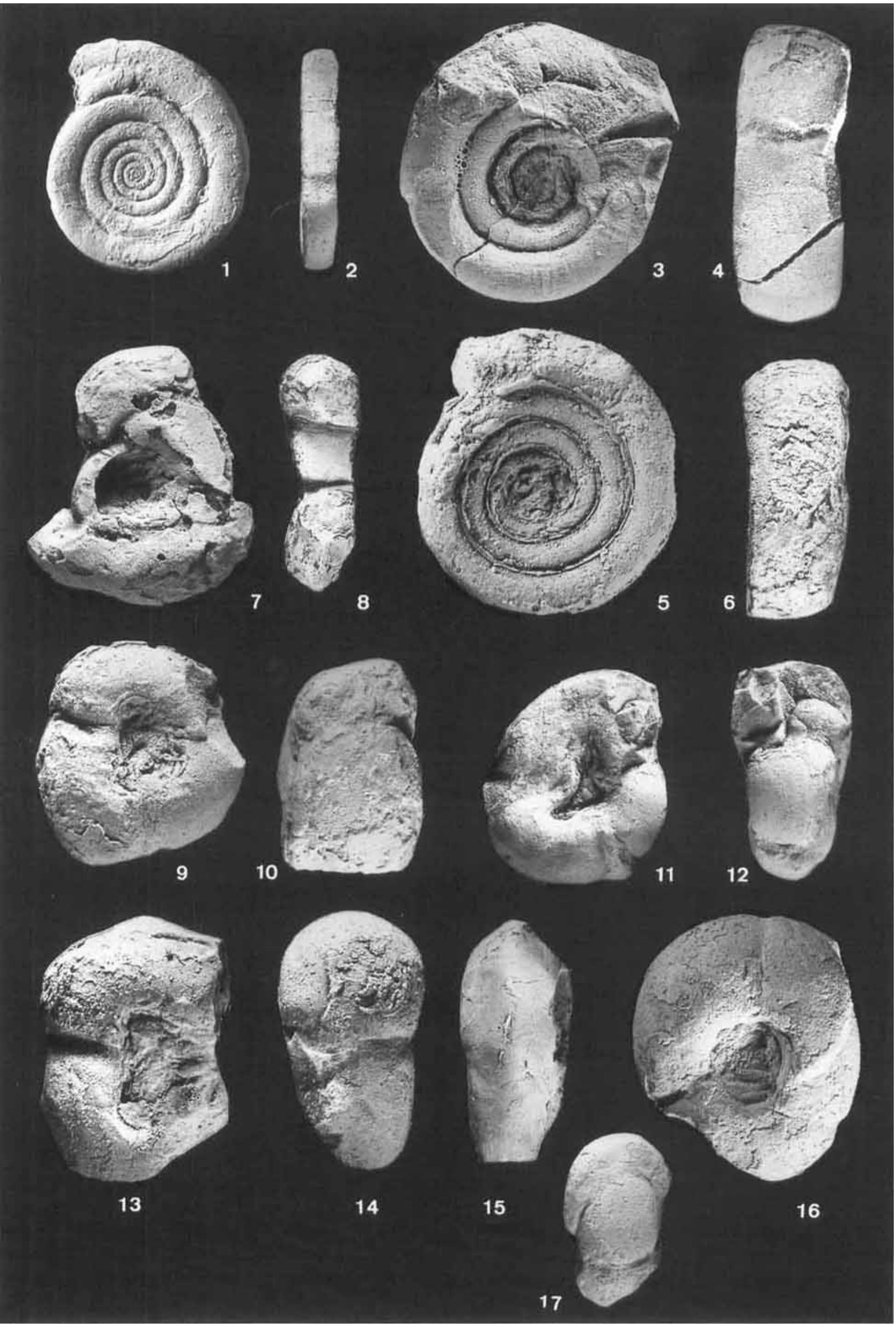

Plate 3 


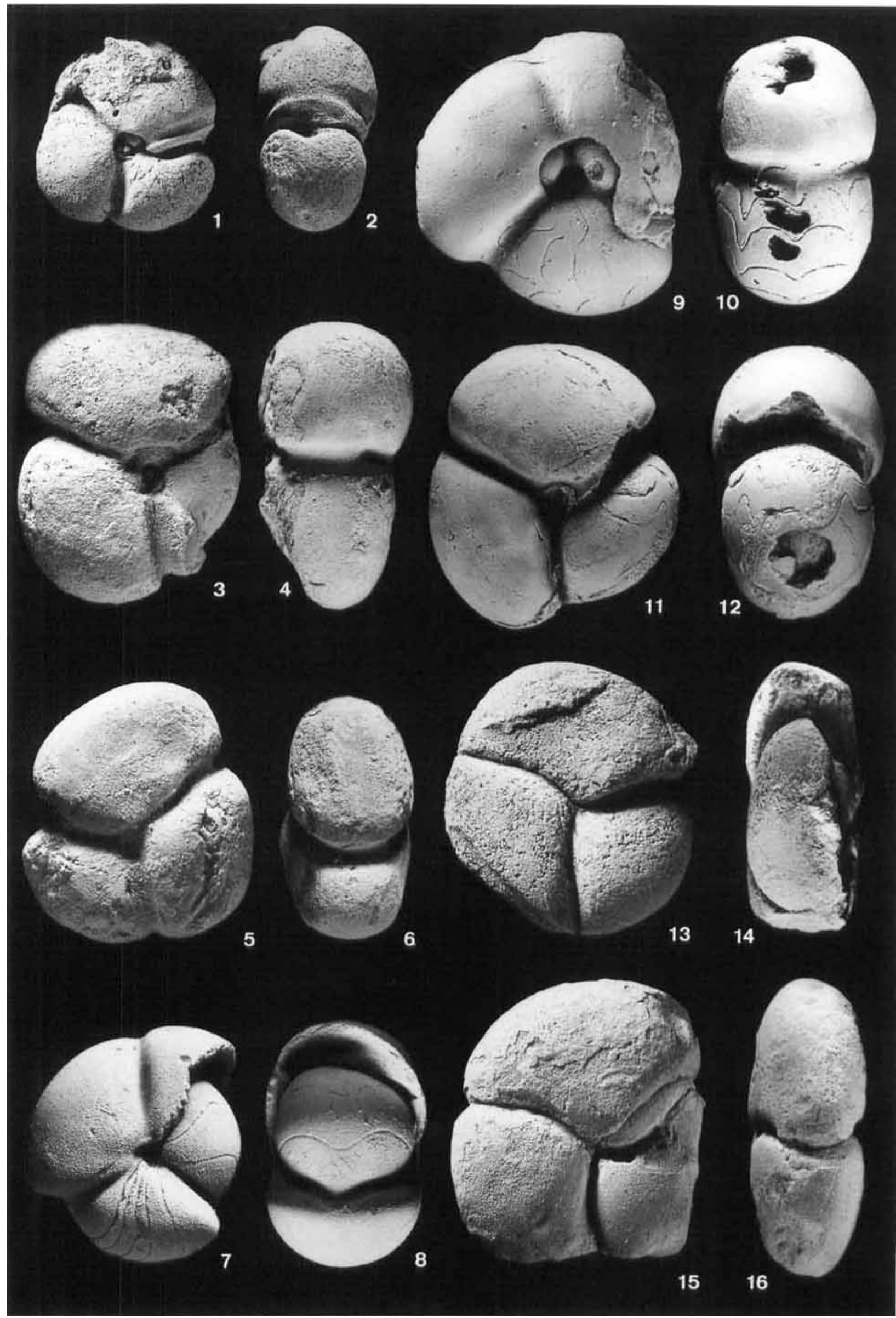

Plate 4 




Plate 5 